AGAINST EVERY HUMAN LAW:

THE TERRORIST THREAT TO DIPLOMACY

Andrew Selth

Sub-thesis submitted in partial fulfilment of the requirements for the degree of Master of Arts in International Relations at the Australian National University

May 1985

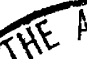


This thesis is based on research carried out while I was a full-time postgraduate student in the Department of International Relations, Research School of Pacific Studies, at the Australian National University from March 1984 to March 1985. The views expressed in this thesis are mine alone and should not be taken to represent those of any other person, the Australian National University, the Australian Government or any of its instrumentalities.

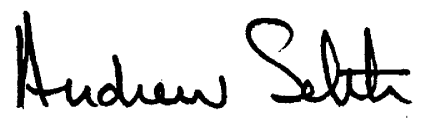

(Andrew Selth) 
Page

ACKNOWLEDGEMENTS

ABBREVIATIONS ii

NOTE ON SOURCES iv

NOTE ON TERMS USED V V

INTRODUCTION

CHAPTER I THE BACKGROUND 8

CHAPTER II THE PROBLEM 26

Diplomats and Diplomatic Facilities

as Terrorist Targets

CHAPTER III THE COMPLICATION

State-Sponsored Terrorism

CHAPTER IV THE RESPONSE

Anti-Terrorist Measures

CHAPTER V THE RESULT

The Challenge to Diplomacy

POSTSCRIPT

APPENDIX A Terrorist Incidents Involving Foreign Diplomats, January 1968-April 1983, by Type

APPENDIX B Countries Whose Diplomats Have Been Victimized by International Terrorism

APPENDIX C Locations of International Terrorist Incidents Involving Foreign Diplomats

APPENDIX D Groups Allegedly Responsible for

Terrorist Incidents Involving Foreign Diplomats, January 1968-April 1983

APPENDIX E The Vienna Convention on Diplomatic Relations (1961)

APPENDIX F Organisation of American States: Convention to Prevent and Punish Acts of Terrorism Taking the Form of Crimes Against Persons and Related Extortion that are of International Significance (1971) 
Page

APPENDIX G United Nations Convention on the

Prevention and Punishment of Crimes

Against Internationally Protected

Persons, Including Diplomatic Agents (1973)

SELECT BIBLIOGRAPHY 


\section{ACKNOWLEDGEMENTS}

This thesis represents the culmination of a year's study in the Department of International Relations at the Australian National University and I should like to thank all those who have contributed in any way to its preparation. Not all can be named here, but there are some to whom special consideration is due. Without the support of Garry Woodard and Jeff Benson I would not have been free to undertake this project and for their help I am very grateful. My time at the ANU was also made possible through the grant of an Australian Public Service Postgraduate Study Award. While at the university I profited from, and greatly enjoyed, my association with Mr Geoffrey Jukes, Dr T.B. Millar, Dr Jim Piscatori and Major Mike Smith. Mrs Shirley Steer not only typed this thesis but during the year was tireless in her efforts on behalf of the MA(IR) students. I was also very fortunate in having, as the supervisor of this thesis, Dr Grant Wardlaw of the Australian Institute of Criminology. His expertise and friendship were shared with equal generosity. Thanks are also due to Mrs Jane Lee and Mrs Dawn Richards of the Department of Foreign Affairs Library for their help with sources. As always, I am indebted to Michael Birch and Kim Jackson for their unfailing support and encouragement. Finally, I should like to thank Patti Collins, without whom this thesis would have never been written. 


\section{ABBREVIATIONS}

AFP

AID

ALN

ANC

ASALA

ASIO

BR

BSO

CIA

DGI

DPRK

EOKA

ETA

FALN

FAWA

FAR

FRG

HIRO

HRB

ILC

IRA

KGB

$\mathrm{M}-19$

MLN

Mossad
Australian Federal Police

Agency for International Development

Acao Libertadora Nacional (National Liberating Action)

African National Congress

Armenian Secret Army for the Liberation of Armenia Australian Security Intelligence Organisation Brigate Rosse (Red Brigades)

Black September Organisation

Central Intelligence Agency

Direccion General de Intelligencia

Democratic Peoples Republic of Korea (North Korea)

Ethniki Organosis Kyprion Agoniston (National Organisation of Cypriot Fighters)

Euskadi ta Askatasuna (Freedom for the Basque Homeland)

Fuerzas Armadas de Liberacion Nacional (Armed Forces of National Liberation)

Foreign Affairs Womens Association

Fuerzas Armadas Rebeldes (Rebel Armed Forces)

Federal Republic of Germany (West Germany)

Hrvatska Ilegalna Revolucionarna Organizacija

(Croat Illegal Revolutionary organisation)

Hrvatsko Revolucionarno Eratsvo (Croatian

Revolutionary Brotherhood)

International Law Commission

Irish Republican Army

Komitet Gosudarstvennoi Bezopasnosti (Committee for State Security)

Movimiento 29 Abril (April 19 Movement)

Movimiento de Liberacion Nacional (National

Liberation Movement)

Central Institute for Intelligence and Security 


$\begin{array}{ll}\text { MR-8 } & \text { Movimento Revolucionario do Outubre } 8 \\ & \text { (Revolutionary Movement } 8 \text { October) } \\ \text { NATO } & \text { North Atlantic Treaty Organisation } \\ \text { NSD } & \text { National Security Directive } \\ \text { OAS } & \text { Organisation of American States } \\ \text { OPEC } & \text { Organisation of Petroleum Exporting Countries } \\ \text { PDRY } & \text { Peoples Democratic Republic of Yemen (South Yemen) } \\ \text { PFLP } & \text { Popular Front for the Liberation of Palestine } \\ \text { PLO } & \text { Palestine Liberation Organisation } \\ \text { PSCC } & \text { Protective Services Coordination Centre } \\ \text { RAF } & \text { Rote Armee Fraktion (Red Army Faction) } \\ \text { ROK } & \text { Republic of Korea (South Korea) } \\ \text { SAC-PAV } & \text { Standing Advisory Committee for Commonwealth/State } \\ & \text { Cooperation on Protection Against Violence } \\ \text { UDBA } & \text { Uprava Drzavne Bezbednosti (State Security Service) } \\ \text { UHRO } & \text { Ustasa Hrvatska Revolucionarna Organizacija } \\ & \text { (Rebel Croat Revolutionary Organisation) } \\ \text { UK } & \text { United Kingdom } \\ \text { UN } & \text { United Nations (Organisation) } \\ \text { UNGA } & \text { United Nations General Assembly } \\ \text { URA } & \text { United Red Army } \\ \text { US } & \text { United States (of America) } \\ \text { USSR } & \text { Union of Soviet Socialist Republics } \\ & \end{array}$




\section{NOTE ON SOURCES}

There is now a large body of published work on the subject of terrorism but, for a number of reasons, very little of it has been written by the terrorists themselves. The clandestine nature of their operations is partly responsible. Also, with some notable exceptions like the Brazilian Carlos Marighela, few modern terrorists have tried to construct a coherent theoretical base for their actions. Instead, they have tended to eschew written statements for 'the propaganda of the deed', relying on the international news media to carry their message to the public. Some material written or recorded by terrorists, however, can be found in contemporary periodicals, official papers and other secondary sources. Because it is usually included to support a point of argument such material must be treated carefully, but can still be useful for the purposes of a study such as this.

As discussed in the thesis, statistics on terrorist incidents are notoriously unreliable, varying widely with the definition of terrorism used, the size of the data base and, often, the ideological position of the collection agency. Yet, here again, the material published by bodies such as the US State Department's Office for Combatting Terrorism and the Rand Corporation can be very useful, providing that its shortcomings are kept in mind. If not precise figures, such studies can indicate levels of magnitude and reflect trends in terrorist operations over time.

The growing interest in terrorism among scholars and officials has also prompted a number of collections of documents relating to the subject. As these works conveniently and accurately reproduce the texts of resolutions and conventions scattered throughout the records of international organisations and national governments, they have been used in preference to the original sources. 
It has been said that 'terror like love may be difficult to define but [is] readily recognizable to the involved'. I While some of the problems of terminology inherent in a study of terrorism are touched upon in this thesis, it is necessary at the outset to establish an understanding of some of the terms used.

Terrorism is a highly complex phenomenon and viewed in a political context is susceptible to a wide range of interpretations. As a consequence, the definition of terrorism has long been a subject of controversy and numerous attempts have been made by politicians, officials and scholars to devise a form of words that can be universally accepted. 2 To date it has proven impossible to satisfy the demands of politics but the needs of scholarship can be met by a number of proposed definitions. For the purposes of this study I have followed that suggested by Grant Wardlaw:

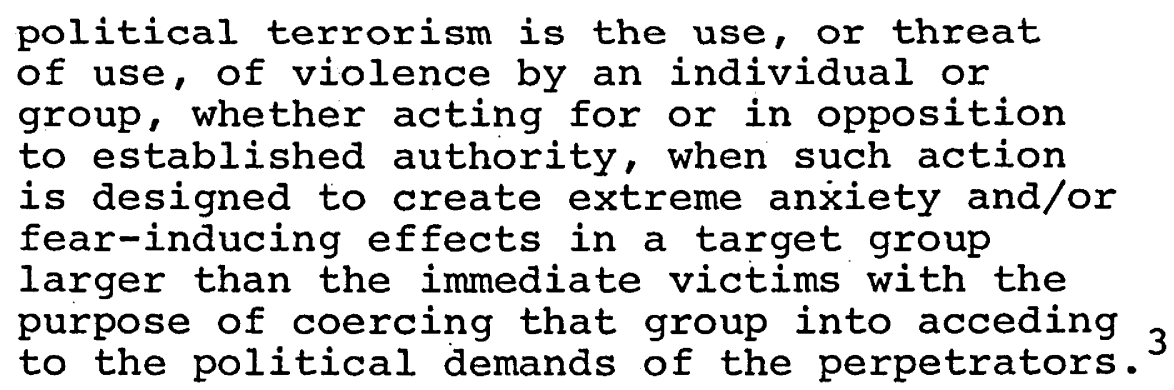

Most acts of terrorism have international repercussions of some kind, but the term 'international terrorism' is used to

1 J.B. Bell, 'Terror: An Overview' in M.H. Livingston (Ed), International Terrorism in the Contemporary World (Greenwood Press, Westport, 1978), p.38.

2 Grant Wardlaw, Political Terrorism: Theory, tactics and counter-measures (Cambridge University Press, Cambridge, 1982), pp.3-17. See also John Dugard, 'International Terrorism: Problems of Definition', International Affairs 50:1 (January 1974), pp.67-81.

Wardlaw, Political Terrorism, p.16. 
describe terrorism conducted with the support of a foreign government or organisation, directed against foreign nationals, institutions or governments, or which directly transcends national boundaries. 4 All terrorist attacks on diplomats and diplomatic facilities thus by definition constitute examples of international terrorism.

A distinction also needs to be made between the terrorism of governments and that used by political extremists and revolutionary groups. This study does include a brief examination of the (usually clandestine) involvement of states in international terrorism, but is not concerned with the 'enforcement terror' ${ }^{5}$ used by totalitarian regimes to keep power. It does not look at the calculated use of terror by states in overt military conflicts such as the Second World War or Vietnam War, 6 nor considers the 'balance of terror' which currently governs the nuclear confrontation between the superpowers. 7 Rather, this thesis concentrates on 'agitational terror' 8 against states and international institutions. In the terms of Chomsky and Herman's provocative analysis, it is a study not of 'wholesale violence'

4 This definition is drawn from Terropist Incidents Involving Diplomats: A statistical overview of international terrorist incidents involving diplomatic personnel and facilities from January 1968 through April 1983 (Department of State, Washington, 1983). It has been expanded, however, to include attacks by terrorists upon nationals or institutions of their own state where these occur in a third country, such as attacks by the Irish Republican Army (IRA) (based in Northern Ireland) against British diplomats and diplomatic facilities abroad. 5

T.P. Thornton, 'Terror as a Weapon of Political Agitation' in H. Eckstein (Ed), Internal War: Problems and Approaches (Collier-Macmillan, London, 1964), p.72.

6 This is done well by Michael Stohl, 'National Interests and State Terrorism in International Affairs', Political Science $36: 1$ (July 1984).

7

This term was first coined by A.J. Wohlstetter, 'The Delicate Balance of Terror', Foreign Affairs 37:2 (January 1959). 
to maintain order and security, but 'retail violence' to precipitate political change. ${ }^{9}$

There have also been numerous attempts to define diplomacy, though with far less controversy. For this thesis I have relied in the first instance on the definition coined by Hedley Bull in The Anarchical Society. To him, diplomacy is :

the conduct of relations between states and other entities with standing in world politics by official agents and by peaceful means. 10

This definition subsumes the more traditional and now outdated explanations of diplomacy offered by sir Ernest Satow and Sir Harold Nicolson. 11 It does not, however, include certain forms of state policy described as 'diplomacy' by scholars like Raymond Aron, Thomas Schelling and Michael Stohl, and which are essential to a discussion of international terrorism. 12 To them, 'diplomacy is bargaining' 13 and the terms of the exchange are set by the power of the parties involved. This view of interstate relations is discussed in the thesis.

As Bull and others have pointed out, not everyone engaged in diplomacy can be described as a diplomat. ${ }^{14}$ For

9 Noam Chomsky and E.S. Herman, The Washington Connection and Third World Fascism (Vol.1 of The Political Economy of Human Rights). (Hale and Iremonger, Sydney, 1980), pp.85-95.

10 Hedley Bull, The Anarchical Society: A Study of order in World Politics (Macmillan, London, 1983), p.162.

11 Sir Ernest Satow, A Guide to Diplomatic Practice (Longmans, Green and Co., London, 1957), p.l and Sir Harold Nicolson, Diplomacy (Oxford University Press, London, 1969), pp.4-5.

12 T.C. Schelling, Arms and Influence (Yale University Press, New Haven, 1966), pp.I $\div 34$, and Stohl, 'National Interests'.

13 Schelling, p.l.

14 Bull, The Anarchical Society, pp.162-167. See also Alan James, 'Diplomacy and International Society', International Relations 6:6 (November 1980), pp.934-935. While the word 'diplomat' was long held to be a solecism, it is now the standard form in the United States and is sufficiently common elsewhere to be preferred over the older word 'diplomatist'. 
the purposes of this study the term is taken to include all members of diplomatic and consular missions who enjoy formal diplomatic status. It also includes government officials on special diplomatic missions or attached to recognised international organisations. This use of the term in some respects exceeds the scope of various international

agreements governing such matters as diplomatic privileges and immunities and excludes certain other internationally protected persons, but realistically includes all members of the diplomatic Establishment who are likely to become targets for terrorist attack. It also recognises that since 1945 diplomatic status has been accorded to a wide range of officials and support staff attached to diplomatic missions and international organisations, whether or not they are professional diplomats. Honorary office holders, while occasionally the victims of terrorists, have been excluded from this category. 


\section{INTRODUCTION}

The proper study of terrorism should seek to explain a phenomenon, not justify it. And it must be realised by all that explanation does not entail justification.

Grant Wardlaw

Political Terrorism (1982)

Over the past fifteen years, terrorism has become a subject for academic debate in much the same way that guerrilla warfare was popular with scholars in the 1950 s and 1960s. A great many books and articles have been written on terrorism since the problem assumed renewed importance around 1968. Some of these studies have approached the subject from an historical perspective. ${ }^{l}$ Others have concentrated on the challenges posed to liberal states ${ }^{2}$ or have looked at the possible state sponsorship of terrorist groups. ${ }^{3}$ While most of these works mention the specific problem of terrorist attacks on diplomats and diplomatic facilities as part of their overall treatment of the subject, few examine it in any detail. Even those recent studies which

1 See for example Roland Gaucher, The Terrorists: From Tsarist Russia to the O.A.S. (Secker and Warburg, London, 1968) and Walter Laqueur, Terrorism (Abacus, London, 1978). 2

Such as J.B. Bell, A Time of Terror: How Democratic Societies Respond to Revolutionary Violence (Basic Books, New York, 1978), Paul Wilkinson, Terrorism and the Liberal State (Macmillan, London, 1977) and Juliet Lodge (Ed), Terrorism: A Challenge to the state (Martin Robertson, Oxford, 1981). 3

In particular, see R.S. Cline and Yonah Alexander, Terrorism: The Soviet Connection (Crane Russak, New York, 1984) and claire Sterling, The Terror Network: The Secret War of International Terrorism (Holt, Rinehart and Winston, New York, 1981). 
concentrate on international terrorism tend to treat the terrorist threat to diplomats only in passing. 4

The scant attention paid to this particular aspect of the terrorist problem is not due to an underestimation of its seriousness. Indeed, the danger has been one of overreaction. Rather, it is because terrorist attacks on diplomats and diplomatic facilities are usually viewed as part of a wider problem and rarely seen as a discrete subject worthy of analysis in its own right. No contemporary terrorist group has attacked only diplomatic personnel and no state has suffered only this kind of threat. Nor has this particular problem been confined to one geographical area or political system. In those relatively few cases where the terrorist threat to diplomats and their facilities has been subject to close analysis the studies have tended to concentrate on certain specialised facets of the problem, such as the implications of such attacks for international law. 5 Carol Baumann's pioneering study of The Diplomatic Kidnappings usefully included an examination of the wider implications of this particular terrorist tactic but did not deal with other kinds of attacks on diplomats and diplomatic facilities. 6

As might be expected, greater attention has been paid to this problem by governments the diplomatic services of which have been placed at risk. With its diplomats and

For example, Yonah Alexander (Ed), International Terrorism: National, Regional and Global Perspectives (Praeger, New York, 1976), David Carlton and Carlo Schaerf (Eds), International Terrorism and World Security (Croom Helm, London, 1975) and M.H. Livingston, International Terrorism.

5

As in M.C. Bassiouni (Ed), International Terrorism and Political Crimes (Charles Thomas, Springfield, 1975), A.E. Evans and J.F. Murphy (Eds), Legal Aspects of International Terrorism (Heath and Co., Lexington, 1978) and N.M. Poulantzas, 'Some Problems of International Law Connected with Urban Guerrilla Warfare: The Kidnapping of Members of Diplomatic Missions, Consular officers and other Foreign Personnel', Annals of International Studies 3 (1972).

6

C.E. Baumann, The Diplomatic Kidnappings: A Revolutionary Tactic of Urban Terrorism (Martinus Nijhoff, The Hague, 1973). 
diplomatic facilities among the most popular targets for terrorist attack the United States (US) government, primarily through the state Department and Central Intelligence Agency (CIA), has for some years now made efforts to study this aspect of international terrorism and devise appropriate counter-measures. During the last ten years, spending on State Department security has increased more than 20-fold from $\$ 22.6$ million in 1975 to $\$ 497.3$ million planned in $1985 .^{7}$ As the number of states affected by terrorist attacks has grown and as this particular problem has attracted greater attention in international fora, so other governments have begun to take this problem more seriously. Academic interest is now growing but apart from Brian Jenkins of the Rand Corporation few scholars appear to have published their thoughts on this aspect of international terrorism. ${ }^{8}$

The lack of scholarly attention paid to this problem is surprising, for over the past fifteen years terrorist attacks on diplomats and diplomatic facilities have been steadily growing to the point that they now constitute nearly 40 per cent of all international terrorist incidents. 9 According to the US Department of State, the diplomats of at least 113 countries have been attacked since 1968, by more than 100 terrorist groups. 10 one noted British scholar

7 'US Embassies Try to Maintain Open Society in Tight Security', International Herald Tribune, 2 April 1985, p.9. See also 'Diplomats Forced to Adapt to New Era of Terrorism', Washington Post 15 November 1984, p.21 and Frank Perez, 'Terrorist Target: The Diplomat', Address by Frank Perez, Deputy Director of the Office for Combatting Terrorism, before the conference on terrorism sponsored by the Instituto de Cuestiones Internationales, Madrid, 10 June 1982, Current Policy, 402 (10 June 1982).

8 See for example B.M. Jenkins, Diplomats on the Front Line, Rand Paper P-6749 (Rand Corporation, Santa Monica, 1982).

9 B.M. Jenkins, New Modes of Conflict, Rand Report R-3009-DNA (Rand Corporation, Santa Monica, 1983), p.14.

10 Terrorist Incidents Involving Diplomats, p.3 and p.5. 
in this field has even suggested that 'the profession of diplomat must now rank as one of the most dangerous in the world'. 11 There is growing evidence too that a number of states like Libya and Iran support these practices and have even resorted to terrorism of this kind themselves as a form of 'coercive diplomacy'. Inevitably, terrorist attacks on diplomats and the increasing use of terrorism by some states as a tool of their foreign policies have had a profound effect on the conduct of diplomacy and, many would argue, international relations in general. As early as 1970 the Chairman of the US House of Representatives Subcommittee on Inter-American Affairs was warning that 'unless something is done to remedy this situation, international relations may come to be dictated by the whims and self-designated necessities of guerrillas, terrorists and other extreme radical elements'.12

Consideration of this problem at an international level is greatly complicated by the fact that 'at base, terrorism is a moral problem.13 and, naturally enough, provokes such emotional reactions. What may be considered justifiable violence by one state can be seen as illegitimate by another, depending on its political viewpoint. Hence the ubiquity of the phrase 'one man's terrorist is another man's freedom fighter'. Differences persist despite the fact, or perhaps even because of the fact, that at various times throughout history most states have been guilty of terrorism of one kind or another. It is one of the many ironies of international debate on the nature of terrorism that many states could still be included in their own proposed definitions of the problem. Because assessments of terrorism are usually so subjective, argument has tended to revolve around ideological

11 Paul Wilkinson, 'After Tehran', Conflict Quarterly (Spring 1981), p.5.

12 'Safety of U.S. Diplomats', Hearings before the Subcommittee on Inter-American Affairs of the Committee on Foreign Affairs, US House of Representatives, 91st Congress, Second Session (27 April 1970).

13 Wardlaw, Political Terrorism, p. 4 . 
positions rather than objective political analysis. Yet agreement has been reached regarding terrorist attacks on diplomats and diplomatic facilities, suggesting that in this area at least some further progress might be possible. In addition, the rare international consensus on this particular aspect of the terrorist problem lends weight to the claim that it is worth closer examination.

The following study is intended to help fill this need. It presents a broad overview of terrorist attacks on diplomats and diplomatic facilities, looking at the problem first in historical perspective and then in terms of its current dimensions. It includes a brief survey of the way in which states have exercised their responsibilities to protect diplomats, as required under international law, and examines the growing problem of terrorism being used by states as a tool of their foreign relations. This study looks also at the various responses states have made to counter this threat to diplomatic practices and in particular considers the impact of the current terrorist problem on the conduct of diplomacy. It offers a number of comments on the likely course of international relations in this field, in the light of the US Administration's view that international terrorism is part of a Soviet inspired campaign to destroy the institution of diplomacy and undermine world stability.

It is argued that there has always been a need to provide protection for diplomats, but that the dangers they face are now greater than ever before. Since the 1960s, terrorism has placed considerable strains on the international system as a whole and diplomats in particular have been identified as legitimate targets for attack. Yet shorn of the political rhetoric and journalistic hyperbole that these attacks have engendered, the problem is not as grave as some states have claimed. Diplomats and diplomatic facilities remain under constant threat and the conduct of diplomacy is being adversely affected, but diplomacy itself is secure. Almost without exception terrorist attacks are aimed at particular states, groups of states or states in general, not the 
institution of diplomacy, on which the terrorists themselves also depend. They both seek to use international diplomacy to further their own causes and ultimately aspire to diplomatic status of their own - either as a terrorist organisation, like the Palestine Liberation Organisation (PLO), or as a result of having successfully seized power and achieved formal statehood.

This is a fine distinction, and one that offers cold comfort to the diplomats and governments at risk, but it is important in terms of the responses to the terrorist threat now being considered by certain states. Despite some dire predictions, diplomacy itself will survive as it has always done, adapting to changes in the international environment and insured against collapse by the recognition of all states that diplomacy continues to perform an essential function in international affairs. Indeed, by provoking a conflict between the traditional values of international relations and those centred on national self-determination, terrorist attacks have encouraged cooperation between states against universally disruptive political violence of this kind and so reinforced traditional norms, among them the security of diplomatic intercourse. 14 There is a danger from the blatant disregard of diplomatic conventions by a few maverick states but the institution of diplomacy would be more threatened by an over-reaction on the part of others. Ideologically coloured visions of international terrorism as a global plot and an emphasis on military responses to terrorist acts deny diplomatic options as much as terrorist attacks themselves, risk an escalation in the level of violence and undermine public confidence in the usefulness of international legal means to settle disputes of world concern.

\footnotetext{
14 Martha Crenshaw, 'The International Consequences of Terrorism', Paper prepared for delivery at the 1983 Annual Meeting of the American Folitical Science Association, The Palmer House, 1-4 September 1983, p.1.
} 
All governments need to recognise that diplomacy has become a hazardous profession and to take more effective measures to protect diplomats and their families from terrorist attacks. Yet it must also be understood that terrorism will never disappear. In these circumstances perhaps the best that can be hoped for is that the problem can be managed in such a way that, like criminality, it is made to bring the least harm to the fewest people and is not permitted to disrupt the normal functioning of international society. 
Chapter I

THE BACKGROUND

Diplomacy and Terrorism

Violence and war try to settle in a short time, and by a sudden dissipation of energy, difficulties that ought to be dealt with by the subtlest analysis and the most delicate tests - for the object is to reach a state of unforced equilibrium.

Paul Valery

History and Politics (1931)

Diplomacy and terrorism share a number of parallels. Both have their roots in the ancient past and both have developed in response to changes in the international environment. 'The purpose of each is to persuade and prevail, and both rely heavily on symbolism'. 1 Yet here the similarity ends. Diplomacy has developed as an organised tool of states within a recognised international system, while terrorism has traditionally been used by disparate non-state actors against established authority. Diplomacy attempts to manage political change through compromise and peaceful negotiation, where terrorism seeks radical change by violent means. Diplomacy has been directed towards adjustment and conciliation, goals largely incompatible with ideology, yet terrorism almost always springs from a strong ideological base rarely sympathetic to such an approach. ${ }^{2}$ Diplomatic

1 J.E. Karkashian, 'Too Many Things Not Working' in M.F. Herz (Ed), Diplomats and Terrorists: What Works, What Doesn't: A Symposium (Institute for the Study of Diplomacy (Georgetown University), Washington, 1982), p.6 (emphasis retained)

2 Maurice Keens-Soper, 'The Liberal Disposition of Diplomacy', International Relations 5:2 (November 1975), p.909. 
negotiations have never been far from considerations of power but traditionally diplomacy and terrorism have been found at opposite ends of the political spectrum.

Throughout history, diplomats have been granted special protection from violence and despite a number of isolated incidents the worlds of terrorism and diplomacy have remained poles apart. This situation, however, is now changing. Since the late 1960s diplomats and diplomatic facilities the world over have become popular targets for terrorist attack and terrorism is now a major topic for discussion on the agenda of international negotiating groups. With the increasing involvement of some states in insurgent terrorism the traditional division between diplomacy and terrorism is becoming blurred and the conduct of international relations more uncertain. In order fully to appreciate the changes which have taken place and the impact of recent terrorist attacks on diplomatic targets it is necessary first to consider the problem in historical perspective.

As Carol Baumann has pointed out, terrorist attacks on diplomats and diplomatic facilities, while a relatively new phenomenon, base their effectiveness on a number of very old and simple realities. ${ }^{3}$ Relations of some kind have always been considered necessary between states and have always been conducted through some means of political intercourse. This has required official intermediaries whose status and behaviour have been subject to agreement between the parties involved. Indeed, diplomatic agents are probably the world's oldest international institution and the codes regarding their protection and conduct by custom antedate all other rules of international law. ${ }^{4}$ Examples of formal diplomatic

3 Baumann, p.32.

4 J.E.S. Fawcett, 'Kidnappings versus Government Protection', World Today 26:9 (September 1970), p.359. See also Ira stechel, 'Terrorist Kidnapping of Diplomatic Personnel', Cornell International Law Journal 5:189 (Spring 1972), p.190. 
exchanges can be found as long ago as $3000 \mathrm{BC}$ and the concept of resident envoys was discussed as early as $1380 \mathrm{BC} .^{5}$ There were several precedents in the days of the Greek city states but it was the second half of the fifteenth century before accredited resident envoys began to make their regular appearance in Renaissance Italy.

Pressures associated with the Italian wars after 1494, the expansion of trade and the ferment of the Reformation all encouraged the spread of resident diplomacy, which by the sixteenth century could be found throughout Europe. It was not until after the Peace of Westphalia in 1648, however, and the evolution of a society of independent sovereign states, that the establishment of permanent diplomatic missions became common practice. With the resulting multiplication of contacts came a change in the methods and characteristics of diplomacy but in general it emerged as 'an organising institution, bearing its distinctive styles and manners, and its own networks and procedures, rules, treaties and other commitments'. 6 Although the first records of diplomatic activity were to be found outside Europe, resident diplomacy seems never to have developed there. The evolving European system was in many ways alien to these other civilisations but as the Western states encroached ever more insistently on their interests these other powers found acceptance of European conventions of diplomatic intercourse increasingly difficult to resist. By 1900 Western international law and customs, and as a corollary resident diplomacy, extended throughout the world. 7

5 Peter Barber, Diplomacy (The British Library, London, 1979), p.14 and Adam Watson, Diplomacy: The Dialogue Between States (Eyre Methuen, London, 1982), p.84.

6 watson, p.17. The growth of diplomacy during this period is examined in greater detail by Sir Harold Nicolson in The Evolution of the Diplomatic Method: Being the Chichele Lectures delivered at the University of oxford in November 1953 (Constable, London, 1954).

7 Barber, p.51. 
The demise of the colonial empires after 1945, the emergence of over eighty new states and the proliferation of international organisations all brought pressures for a reconsideration of some of these practices. Many new states in particular viewed with suspicion a system which stemmed primarily from European culture and traditions and in the development of which they had played no part. To the more radical states this was the same system which had permitted the spread of European colonialism and which still worked to prevent the Third World from sharing in the power and resources to which they felt all states were entitled. 8 Yet, to a surprising extent, states of all geographical regions, political colours, cultures and stages of development have been willing to embrace what Hedley Bull has called 'the often strange and archaic diplomatic procedures that arose in Europe in another age'. 9 The new states have placed considerable reliance on the diplomatic system as an agency through which to achieve quite fundamental changes ${ }^{10}$ and calls for amendments to the system itself have almost without exception been made in its own idiom. These calls have not always been received sympathetically by the older states but despite this 'the contemporary global system is gradually evolving new rules and conventions to replace those of its more purely European predecessor'. 11

One convention which has always had universal application and is unlikely markedly to change is that regarding the personal inviolability of diplomatic agents. As resident

8 Keens-Soper, p.913. See also P.J. Boyce, Foreign Affairs For New States: Some Questions of Credentials (University of Queensland Press, St. Lucia, 1977), p.201.

9 Bull, The Anarchical Society, p.183.

10 See for example C. Farrands, 'Perspectives on Negotiation: Diplomacy and Regime Change', in B. Buzan and R.J.B. Jones (Eds), Change and the Study of International Relations: The Evaded Dimension (Pinter, London, 1981), p.86.

11 Watson, p.19. 
diplomacy spread, so the principle of inviolability and certain associated immunities also developed. Prompted initially by the fact that the diplomat represented the person of his sovereign, the justification for these privileges soon came to be accepted as one of functional necessity. ${ }^{12}$ By 1625 Hugo Grotius could write that:

$$
\begin{aligned}
& \text { There are two maxims in the law of } \\
& \text { nations relating to ambassadors which } \\
& \text { are generally accepted as established } \\
& \text { rules: The first is that ambassadors } \\
& \text { must be received and the second is that } \\
& \text { they must suffer no harm. } 13
\end{aligned}
$$

These fundamental laws and the special duties of protection owed by receiving states were expressed in the norms of diplomatic reciprocity which emerged from the Peace of Westphalia and were soon strengthened by municipal laws in code and practice. Most of the privileges found today were in existence in some form by 1720.14 They were further refined at the Congress of Vienna in 1815, when an attempt was made to resolve the prevailing confusion over precedence, consistent with the nominal equality of states. The codes of behaviour established then soon became universal and many remain in force today.

International developments did not prompt another major effort to codify the rights and privileges of diplomatic agents until 1921 when the Sixth International Conference of American States met in Havana to consider draft conventions on diplomatic and consular officers. The drafts also specified

\footnotetext{
12 There currently exist three theories to account for the development, and to justify the continuation, of diplomatic privileges. The first rests on the diplomat's representative function, the second is based on the theory of extraterritoriality while the third, and now most favoured theory, is that of pure functional necessity. See for example B. Sen, A Diplomat's Handbook of International Law and Practice (Martinus Nijhoff, The Hague, 1979), pp.80-83.

13 Quoted in Sen, p.6.

14 Barber, p.26.
} 
the position of personnel representing international organisations like the newly-formed League of Nations and reaffirmed the principle of non-interference by diplomats in the affairs of the receiving state. ${ }^{15}$ Although these two conventions were signed in 1928, consideration of the matters included in them was incomplete, prompting the International Law Commission (ILC), at its first meeting in 1949, to select diplomatic intercourse and immunities as a subject for early examination. Work began in 1954 and culminated in the United Nations Conference on Diplomatic Intercourse and Immunities held in Vienna in 1961. Attended by the representatives of 81 countries (including 24 created since 1945), the Conference agreed upon a comprehensive multilateral convention which 'codified and restated the law with regard to the status of the diplomat and all members of his staff'.16

For the purposes of this study, two Articles of the Vienna Convention on Diplomatic Relations are particularly important. Article 22 states, in part:

1. The premises of the mission shall be inviolable. The agents of the receiving State may not enter them, except with the consent of the head of mission.

2. The receiving state is under a special duty to take all appropriate steps to protect the premises of the mission against any intrusion or damage and to prevent any disturbance of the peace of the mission or impairment of its dignity. 17

Article 29 of the Convention extends this fundamental principle to diplomatic agents themselves:

15 Sen, pp.78-79 and Baumann, p.37.

16 Stechel, pp.193-194.

17 The full text of the Vienna Convention on Diplomatic Relations is included in I. Brownlie (Ed), Basic Documents in International Law (Clarendon Press, Oxford, 1983), pp.213-229 and is reproduced as Appendix $E$ of this thesis. 
The person of the diplomatic agent shall

be inviolable. He shall not be liable to any form of arrest or detention. The receiving state shall treat him with due respect and shall take all appropriate steps to prevent any attack on his person, freedom, or dignity.

Article 29 was considered to be completely in accordance with the accepted principles of international law and practice and was adopted without amendment from the draft Articles prepared by the ILC. ${ }^{19}$ The Convention entered into force on 24 April 1964 with 63 signatures and, with some 140 states now party to it, has become universal practice. 20

Although disagreement over the scope of the proposed convention had restricted the Vienna Conference to an examination of formal interstate relations, the 1961 Convention and its companion on Consular Relations in $1963^{21}$ were soon followed by a number of additional international agreements which extended similar privileges and rights of protection to members of special diplomatic missions and specified international organisations. 22 The agreements were still open to different interpretations according to the

\section{$18 i b i d$.}

19 Stechel, p.195 and J.F. Murphy, 'The Role of International Law in the Prevention of Terrorist Kidnapping of Diplomatic Personnel' in Bassiouni, p.288.

20 Michael Palliser, 'Diplomacy Today' in Hedley Bull and Adam Watson (Eds), The Expansion of International Society (Clarendon Press, Oxford, 1984), p.374.

21 The Vienna Convention on Consular Relations came into force on 19 March 1967. As Poulantzas has noted, there is a growing tendency today for states to entrust their diplomatic representatives with their consular services, with the result that the difference in treatment given to diplomatic envoys and consular officers, in some areas always very slight, is gradually diminishing. Poulantzas, p.144.

22 These additional agreements include the convention on Special Missions, the Convention on the Representation of states in their Relations with International Organisations, the Convention on the Privileges and Immunities of the United Nations, and the Convention on the Privileges and Immunities of the Specialised Agencies. See J.F. Murphy, 'Protected Persons and Diplomatic Facilities' in Evans and Murphy, p.279. 
historical traditions and political outlook of states but they 'raised the oodification, if not the actual protection, of the personal inviolability of diplomats to a new level of international validity'. 23 It was widely recognised that in times of heightened international competition and growing functional interdependence diplomacy was likely

to assume an increasingly important role. This role could only be fulfilled if there was universal agreement about the conditions under which state representatives could work. It is thus ironic that, within only a few years of the most complete exposition of these time-honoured rules and practices there should be an unprecedented succession of attacks on diplomats and seizures and bombings of diplomatic facilities. ${ }^{24}$.

Although terrorism does not enjoy quite the same historical credentials as diplomacy, it is still an ancient practice. Scholars searching for early examples of organised terror have identified antecedents to modern groups in the sicarii, a religious sect active in the zealot struggle in Palestine from 66-73 $\mathrm{AD}$ and the Assassins, an Ismaili Muslim sect which between the eleventh and thirteenth centuries sent agents on missions throughout the Islamic world. 25 Because of the nature of totalitarian governments since antiquity the origins of terror organised as a political system are difficult to determine but by common consent are attributed first to the French Revolution of 1789-1799, from whence the words 'terrorism' and 'terrorist' are derived. Examples of insurgent terrorism occur in the years that follow but the doctrine only found real expression in Russia in the second half of the nineteenth century when extremists

23 Baumann, pp. 40-41.

24 Fawcett, p.359.

25 Laqueur, Terrorism, pp.18-20, Paul Wilkinson, Terrorism: International Dimensions - Answering the Challenge, Conflict Studies 113 (Institute for the Study of Conflict, London, 1979), p.l and Wardlaw, Political Terrorism, p.18. 
inspired by the ancient concept of justifiable tyrannicide carried out numerous attacks against representatives of the Czarist state. 26 The tactics of Narodnaya Volya and other Russian terrorist movements were soon emulated by groups elsewhere and by the twentieth century terror as an organised political tactic was being used by anarchists in France, Spain, Italy and the United States. 27 The ill-fated Bakuninist International believed it was engaged in an international campaign of terrorist violence. More importantly, terror was adopted as a strategy by radical nationalist groups in Ireland, Macedonia, Serbia, Armenia and India. With the notable exception of the Irish campaign, however, these early examples failed to achieve more than minor tactical successes. 28

From the turn of the century until the mid-1960s, terrorism was mainly the preserve of nationalist separatist movements and extreme right wing groups. 29 The successful campaigns against the British in Palestine between 1944-1948 and in Cyprus between 1955-1959, for example, were characterised by terrorist strategies on the part of the

\section{Laqueur, Terrorism, p.35 and Gaucher, pp.3-102.}

27 Walter Laqueur is of the opinion that 'Psychologically interesting, the ere des attentats was of no great political significance' (Terrorism, p.27). In one sense this may be true, but given that over fifteen national figures in the United States and Europe, including three US Presidents, were assassinated in the fifty years between 1865-1918, there must have been some impact on the international scene. See John Williams, Heyday for Assassins (Heinemann, London, 1958), p.230.

28 The Irish terrorist campaign of 1918-1921 was not only uniquely successful, but it directly inspired the tactics of other terrorist groups like the Zionist Irgun Zvei Leumi and the Cypriot Ethniki Organosis Kyprion Agoniston (EOKA). See Andrew Selth, 'Romantic Ireland's Dead and Gone', RUSI (Journal of the Royal United Services Institute for Defence Studies) 128:1 (March 1983), pp.44-47.

29

Walter Laqueur, 'Introduction' in Walter Laqueur (Ed), The Terrorism Reader: A Historical Anthology (Wildwood House, London, 1979), p.119. 
insurgents. 30 The revolutionary struggles of this period, on the other hand, were dominated by three schools of strategic thought none of which viewed terrorism as an effective tool for political change. ${ }^{31}$ While fundamentally opposed on certain key principles, both the Soviet and chinese communists agreed that terrorism should not be accorded an important place in their political-military doctrines. The Bolsheviks were ambivalent about the use of terrorism but to Lenin and Trotsky (and orthodox Marxists still) it was considered elitist adventurism which lowered the political consciousness of the masses. Organisational and political work was felt to be more important. ${ }^{32}$ The Chinese too held misgivings about terrorist tactics. After the failure of the Canton and Shanghai uprisings in 1925-1927 Mao Tse-tung had little faith in urban campaigns of any sort. He was prepared to use terrorist tactics as occasion demanded but placed emphasis on building mass support under the leadership of the party. Unlike the Russians, however, the Chinese saw victory arising from a 'protracted war' conducted by guerrilla armies in the countryside. 33 This strategy enjoyed some authority with insurgents in the developing countries of Asia and Africa, but after 1959 was displaced in Latin America by the Cuban model of revolution.

\section{0}

For first-hand accounts of these conflicts and the rationale behind the use of terrorist tactics by the insurgents, see Menachem Begin, The Revolt (W.H. Allen, London, 1951) and George Grivas, The Memoirs of George Grivas (Longmans, London, 1964).

31 While these three schools are surveyed in Baumann, pp.4-31, a more sophisticated examination of the development of revolutionary military doctrine is given by Bernard semmel in his introduction to Bernard Semmel (Ed), Marxism and the Science of War (Oxford University Press, Oxford, 1981), pp. 13-44.

\section{2}

See the extracts from works by Lenin and Trotsky reproduced in Laqueur, The Terrorism Reader, pp.198-223.

\section{3}

See in particular 'Problems of Strategy in China's Revolutionary War', 'Problems of Strategy in Guerrilla war Against Japan' and 'On Protracted War' in Selected Military Writings of Mao Tse-tung (Foreign Languages Press, Peking, 1966). 
Like that of the Chinese, the Cuban model emphasised the primacy of the struggle in the rural areas. Fidel castro believed that 'the city is a cemetery of revolutionaries and resources ${ }^{34}$ and stressed the development of a rural power base before the 'descent to the city'. 35 Unlike the Soviet and Chinese doctrines, however, little emphasis was given to the initial mobilisation of the population, whose support was expected to flow from the successful establishment of a guerrilla 'foco', or focus. Political considerations were made subordinate to military factors and the armed forces placed at the centre of the revolutionary struggle. According to Regis Debray, who is widely taken to represent Fidel Castro's views, 'the vanguard of the party can exist in the form of the guerrilla foco itself. The guerrilla force is the party in embryo'. 36 In addition, a significant role was given to violence as an act in itself and in Debray's writings at least little concern was shown to relate it to the overall direction of the political struggle. Like the African theorist Frantz Fanon, Debray seemed to feel that violent acts had a certain intrinsic value and need not be rationed to specific circumstances. 37 Ernesto (Che) Guevara, one of Castro's lieutenants, cautioned his fellow revolutionaries on the use of purely terrorist tactics which he felt were of 'negative value' and liable to cause

34 Quoted in Regis Debray, Revolution in the Revolution? Armed Struggle and Political struggle in Latin America (Penguin, Harmondsworth, 1968), p.67.

Debray, p.65.

37 While Fanon's belief in the psychologically 'purifying' effects of revolutionary violence sprang from basically anticolonial sentiments, he shared much in common with Menachem Begin who believed in the need for the Jews to reassert their identity through violent acts ('We fight, therefore we are'). See Frantz Fanon, The Wretched of the Earth (Penguin, Harmonsworth, 1967), pp.27-84 and Begin, pp.26-46. 
disproportionate losses and alienate the population. 38 Yet the philosophy of action enunciated by Debray was to have the greatest impact on Latin American politics over the next decade and beyond.

The success of the Cuban revolution in 1957-1959 encouraged the adoption of the 'foco' theory throughout Latin America. It also prompted a number of isolated attacks on foreign citizens and targets, which during the preceding fifteen years had suffered few such threats. 39 Following the defeat of rural guerrilla groups in Venezuela, Peru, Colombia, Brazil and Guatemala, however, the value of the Cuban model lay in doubt. The emphasis on violence and the primacy of the armed revolutionary over the party - the subjective will over the objective conditions - kept their force, but particularly after the failure of Guevara's own Bolivian expedition in 1967 the 'foco' theory was largely discredited. In the announcement launching his new movement, the Brazilian terrorist leader Carlos Marighela stated:

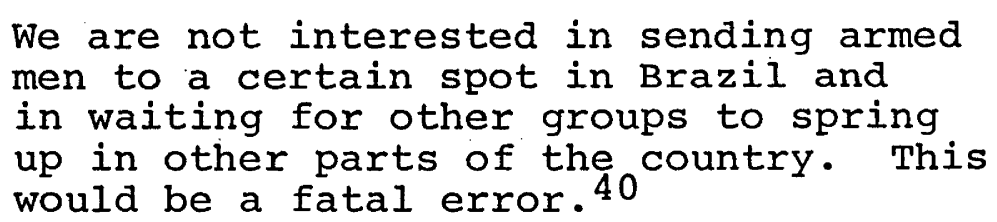

Several commentators have correlated the increase in political terrorism, and the ensuing attacks on diplomats, with this fall into disrepute of the Cuban model for revolution and the consequent shift in focus of the struggle to the major urban and industrial areas. 41

38 Ernesto (Che) Guevara, Guerrizla Warfare (Penguin, Harmondsworth, 1969), p.105.

39 Wilkinson, Terrorism: International Dimensions, p.I.

40 Quoted in Sanche de Gramont, 'How One Pleasant, Scholarly Young Man From Brazil Became a Kidnapping, Gun-Toting, Bombing Revolutionary', New York Times Magazine 15 November 1970 , p.136.

41 see for example Jack Davis, Political Violence in Latin America, Adelphi Paper 85 (International Institute for Strategic Studies, London, 1972), p.20, Baumann, p.18 and Stechel, p.202. 
The crucial date for this transition is by wide agreement 1968, when 'fires spread across the world in much the same style as 1848'.42 In a curious confluence of ideological, nihilistic, romantic and sectional passions, there arose almost at the same time in different parts of the world a number of diverse terrorist groups. 43 In Latin America, for example, Marighela formed the Acao Libertadora Nacional 44 and began his campaign of 'violence, radicalism and terrorism 45 in Brazil. The same year the Fuerzas Armadas Rebeldes 46 in Guatemala abandoned their struggle in the countryside and began a series of terrorist attacks in the cities. In Uruguay, the Tupamaros 47 turned from occasional shootings and bank robberies to widespread bombings and kidnappings. In the Middle East, the Palestinians finally despaired of conventional military methods after the defeat of the Arab armies in the 1967 Six Day War and turned completely to guerrilla and terrorist strategies. 481968 was also a year of social and political turmoil in Europe. closely following the civil disturbances in Paris and the first manifestations of Baader-Meinhof terrorism in the Federal Republic of Germany (FRG), the Angry Brigade appeared

\section{Francois Duchene, 'Introduction' in Civil Violence and the International System, Adelphi Papers 82 (Part 1) and 83 (Part 2), (International Institute for Strategic Studies, London, 1971), Part 1, p.2.}

43 The best public guide to these terrorist and urban guerrilla groups is Peter Janke's excellent Guerrilza and Terrorist Organisations: A world Directory and Bibliography (Harvester Press, Brighton, 1983).

National Liberating Action, or ALN.

45

46

Quoted in Baumann, p.19.

Rebel Armed Forces, or FAR.

47

Strictly speaking, the Tupamaros are members of the Movimiento de Liberacion Nacional, the National Liberation Movement, or MLN. See Janke, p.508.

48 The Palestinians had carried out guerrilla operations prior to 1967, but were only convinced of the need to concentrate on guerrilla and terrorist strategies after 1967. See Helena Cobban, The Palestinian Liberation Organisation: People Power and Politics (Cambridge University Press, Cambridge, 1984), pp.21-57. 
in Britain. The same ideological ferment produced the Brigate Rosse 49 in Italy. At the same time the seeds were sown in the Irish Republican Army and the Trotskyist League of Revolutionary Communists for the ideological splits which produced the Provisional IRA in Ireland and the Rengo Sekigun in Japan the following year. 50

The transition from popularly-supported, rural-based guerrilla struggles to campaigns of violence by smaller, secret terrorist cells not only represented disillusionment with traditional theories of revolution, but also the recognition by extremist groups of all political colours everywhere that fundamental changes had taken place in society. Rapid and widespread urbanisation, 51 technological developments in transport, communications and weaponry, together with changes in political and social attitudes, all contributed to a new global environment. International society was smaller, more sophisticated and more closely interconnected. Because of their reliance on complex technological systems modern states were also more vulnerable to terrorist attack. The strategy chosen by extremist groups was to use these developments to instil fear and apply political pressure through exemplary action of a violent and unexpected kind. The attacks were essentially symbolic acts against targets of equally symbolic value. ${ }^{52}$ As

\section{Red Brigades, or BR.}

50 The Rengo Sekigun, or sometimes just the Sekigun, is known variously in English as the United Red Army (URA), or simply Red Army, but is often called the Japanese Red Army to distinguish it from the Red Army Faction (Rote Armee Fraktion, or RAF). The latter is more popularly known after its German founders as the Baader-Meinhof Group (or Gang). See Janke, pp.17-20 and pp.337-338.

51 Writing in 1973, Baumann cites the example of Brazil with five cities of over one million people and two more with over five million each. At the same time over 70 per cent of the Argentinian population lived in urban areas. Baumann, pp.20-22. 52

Thornton, in Eckstein, p.77. 
David Fromkin and others have noted, 'whereas military and revolutionary actions aim at a physical result, terrorist actions aim at a psychological result'. 53 In this, the terrorists were greatly assisted by the international news media which avidly consumed the details of each fresh incident. Terrorist groups of little or no political power were able to reach beyond their immediate environment and achieve effects on a target community out of all proportion to their numbers, popular appeal or capacity for violence. 54 Indeed, 'a very plausible case can be made that the most important difference between past and present terrorism may be traced to the modern, transnational flow of information'. 55

As some terrorists, notably those in Latin America, achieved some initial tactical successes others were encouraged and by the early 1.970s the world had seen an extraordinary proliferation of terrorist groups. While the political stance of the most important tended to be radically left wing, they were characterised overall by a wide diversity of roots, ideologies and goals. ${ }^{56}$ Their specificity was disguised, however, by a superficial similarity in the tactics

53 David Fromkin, 'The Strategy of Terrorism', Foreign Affairs
53:4 (July 1975), p.693. 54 Wardlaw, Political Terrorism, p.3. This is demonstrated convincingly by the impact of small and otherwise obscure groups such as the South Moluccans (who seized the Indonesian Consulate in Amsterdam in 1975), the 'Group of Alshaheed' which seized the Iranian Embassy in London in 1980 to publicise the claims of the Arab minority in Arabistan and the 'Black December' organisation which seized the Indian High Commission in London in 1973. The latter group appears to have consisted only of the three men involved in this particular incident. 55

56

Wardlaw, Political Terrorism, p. 31.

Over 670 groups have claimed responsibility for at least one international terrorist attack since 1968. While undoubtedly inflated by bogus and very small groups this figure nevertheless represents an extraordinary proliferation of organisations which have adopted terrorist tactics. See Patterns of International Terrorism: 1981 (State Department, Washington, 1982), p.12. Robert Katz claims that at the time of Aldo Moro's abduction in 1978 there were some 209 terrorist groups in Italy, with 181 on the left and 28 on the right of the political spectrum. Robert Katz, Days of wrath: The Public Agony of Aldo Moro (Granada, London, 1980), p.300. 
they adopted and by the fact that they were quick to copy each other's ideas. 57 As terrorist groups realised the opportunities which lay beyond their own national boundaries the scope of their operations expanded and, as circumstances demanded, many formed loose cooperative alliances with other terrorist organisations and sympathetic states. 58 The constraints on action observed by earlier terrorist groups were no longer considered necessary, or sound. 59 Unconsciously echoing the nineteenth century French anarchist Emile Henry,

57 While undoubtedly important, this diffusion of ideas and tactics can be exaggerated. E.S. Heyman claims, for example, that the robbery of former Argentine President Pedro Aranburu's corpse from its crypt by Montoneros in October 1974 prompted 'Burmese radicals' to seize the remains of former UN SecretaryGeneral $U$ Thant from their temporary resting place in Rangoon only weeks later, in order to secure their own demands from the Ne Win regime. (E.S. Heyman, 'The Diffusion of Transnational Terrorism', in R.H. Shultz and Stephen Sloan (Eds), Responding to the Terrorist Threat: Security and Crisis Management (Pergamon Press, New York, 1980), p.190.) The students and Buddhist monks who took $U$ Thant's coffin were acting from purely indigenous motives, however, were by no means terrorists and were unlikely ever to have heard of the Montoneros' action, which was not reported in the Burmese press. See Andrew Selth, 'With the First Shot Fired' (unpublished paper, Rangoon, 1974).

58

An oft-quoted example of this cross-fertilisation of terrorist ideas and international cooperation is the case of the Japanese Red Army's attack on the occupants of the Lod Airport terminal in Tel Aviv in 1972. The operation is alleged to have been planned in Germany by a Palestinian Arab and carried out by Japanese trained in the Democratic Peoples Republic of Korea (DPRK), Syria and Lebanon. The terrorists were provided with funds in Germany and given Russian arms in Italy by an Algerian diplomat financed with Libyan money, before the attack took place in Israel. See P.N. Grabosky, 'The Urban Context of Political Terrorism' in Michael Stohl (Ed), The Politics of Terrorism (Dekker, New York, 1979), p.56, and Geoffrey Fairbairn, 'International Terrorism', Pacific Defence Reporter 5:3 (September 1978), p.94.

59

The Russian terrorists of Narodnaya Valya, for example, would not carry out one operation as it would result in injury to children. The Brazilian terrorists who kidnapped the FRG Ambassador in June 1970 recognised in the communique left at the scene that 'kidnapping endangers the lives of people who have nothing to do with the revolutionary struggle'. (Quoted in Robert Moss, Urban Guerrizlas: The New Face of Political Violence (Alister Taylor, Wellington, 1972), p.206.) This sensitivity to the innocence of their victims was not shared sy later terrorists. Those who took part in the Lod Airport attack, for example, claimed that 'no-one in Israel is innocent'. 
the leader of the Popular Front for the Liberation of Palestine (PFLP) declared in 1970 that:

there can be no political or geographical boundaries or moral limits to the operations of the peoples' camp. In today's world, no one is 'innocent', no one is 'neutral'.60

Individuals, states and international organisations were all made 'legitimate' targets in a vision of world-wide terrorism.

While each of these developments do not in themselves set modern terrorists apart from their historical forebears, they contributed to a coherent strategy of terrorism that was unique. As Brian Jenkins has observed, international terrorism today is:
an offshoot, the newest branch in the evolution of modern revolutionary and guerrilla warfare theories. It elevates individual acts of violence to the level of strategy ... It denigrates conventional military power by substituting dramatic violence played for the people watching. It violates the conventional rules of engagement: it reduces the category of innocent bystanders. It makes the world its battlefield: it recognises no boundaries to the conflict, no neutral nations.61

Such a philosophy of action cast aside all traditional restraints on international behaviour - both in peace and war - and exposed the vulnerability of those whose position and protection depended on the universal acceptance of certain conventions and principles of international law. Foremost among these were diplomats who, together with their facilities, were quickly recognised as holding a unique symbolic value, both to the terrorists as targets and to the states which they represented.

60 Quoted in John Hamer, 'Protection of Diplomats', Editorial Research Reports 11:3 (October 1973), p.766.

61 B.M. Jenkins, High Technology Terrorism and Surrogate War: The Impact of New Technology on Low-Level Violence, Rand Paper P-5339 (Rand Corporation, Santa Monica, January 1975), p.8. 
The increased physical dangers to diplomats that accompanied the growth in international terrorism have come at a time when the functions of diplomacy are more important than ever. Technological developments have made the nuclear balance very fragile, power relationships are more fluid than they have been for centuries, and both state and non-state actors have grown in number and become more interdependent. While in some respects there has been a decline in the role played by traditional diplomacy since it reached its apogee in nineteenth century Europe, and a decline in observance of the rules which govern its workings, professional diplomats continue to have an important place in the conduct of world affairs. 62 As Martin Wight has stated so succinctly:

Diplomacy is the system and the art of communication between powers. The diplomatic system is the master institution of international relations. 63

Thus any threat to the institution of diplomacy must have serious implications for the international order of which it is such an integral part.

62 Wilkinson, 'After Tehran', p.5.

63 Martin Wight, Power Politics (Leicester University Press, Leicester, 1978), p.113. 


\author{
Chapter II \\ THE PROBLEM \\ Diplomats and Diplomatic Facilities \\ as Terrorist Targets
}

\begin{abstract}
Almost every page of history offers some remark on the inviolable rights of ambassadors, and the security of their persons, a security sanctioned by every clause and precept of human and revealed law.
\end{abstract}

Hugo Grotius

De Jure Belli ac Pacis (1625)

Despite the universal acceptance by states of the principle of diplomatic inviolability, the profession of diplomacy has always held its dangers. Throughout history diplomats have been exposed to insults, harassment and violent attack, sometimes at the hands of state authorities but more often from mobs and individuals with a grievance. Diplomats have been strangers in foreign lands, symbolising different political and economic systems, different standards of living, religions, and often different races. As interstate contacts grew and their official representative status came to be accepted as an integral part of international society, so diplomats were increasingly identified as vehicles through which popular grievances might be registered against the sending states. Only this century, however, have diplomats been viewed as worthwhile targets for terrorist attack. 
Once again, it was the Russians who led the way. ${ }^{1}$ After the Bolshevik coup in October 1917 the Social Revolutionary Party assassinated the German Ambassador to the Soviet Republic in an attempt to disrupt relations between Moscow and Berlin. ${ }^{2}$ In 1923 a soviet diplomat at the Lausanne Peace Conference was shot by White Russians and four years later another monarchist killed the soviet Minister to Poland. ${ }^{3}$ In the 1930 s the Counsellor of the German Embassy in Paris was murdered by an anti-Nazi emigre and not long afterwards the German Counsellor in Moscow suffered the same fate. The period immediately before the Second World war and the years that followed its end saw an increasing number of attacks on diplomats and diplomatic facilities. Clifton Wilson, who has carried out perhaps the most detailed study of this subject, could count the deaths of at least thirteen people attached to diplomatic missions between 1945-1967. 'Many more' were injured during the same period. 4 Most of those diplomats killed, however,

1 Some sources cite the murders of the Chancellor of the Japanese Legation and the German Minister in Peking in 1900 as the first examples of terrorist attacks on diplomats this century. Both were killed by rebellious Chinese troops, however, not Boxers as often supposed, and the circumstances surrounding the two incidents are still unclear. See for example Lancelot Giles, The siege of the Peking Legations: A Diary, Edited with an Introduction, 'Chinese Anti-Foreignism and the Boxer Uprising' by L.R. Marchant (University of Western Australia Press, Nedlands, 1970), pp.71-72 and 82-84.

2 See C.W. Thayer, Diplomat (Michael Joseph, London, 1960), p. 202 .

3

Diplomatic ranks have changed little over the years. After the Head of Mission (usually the Ambassador or, in the case of Commonwealth representatives, High Commissioner) follow the Minister, Counsellor, First secretary, Second Secretary and Third Secretary. Non-diplomatic staff (who may, however, be accorded diplomatic rank and privileges) usually take the title of Attache, as in the case of the Defence Attache. Most specialised officers, like the Trade Commissioner, are to all intents and purposes part of the diplomatic staff of the mission. See Sen, pp.30-35.

4

C.E. Wilson, Diplomatic Privileges and Immunities (University of Arizona Press, Tucson, 1967), p.52. See also Boyce, p.201. 
appear to have died as a result not of any particular terrorist intent but from events related to the general social turmoil and political unrest of the time. ${ }^{5}$

There was a small number of isolated terrorist attacks, such as the abduction of the US Ambassador to Brazil in 1949 and an attempt on the life of the US Ambassador to Japan in $1961,{ }^{6}$ but with few exceptions none of the anti-colonial or revolutionary groups of the time seem to have had any policy to attack diplomatic targets. 7 No doubt because the mobilisation of international support was an integral part of their strategies they appear deliberately to have eschewed attacks which risked the alienation of the international diplomatic community. For example, General George Grivas, the leader of the Cypriot EOKA terrorists, declared in his 1953 Preparatory General Plan:

The British must be continuously harried
and beset until they are obliged by
international diplomacy exercised
through the United Nations to examine the
Cyprus problem and settle it in accordance
with the desires of the Cypriot people
and the whole Greek nation.8

When a US Vice-Consul was accidentally killed by an EOKA bomb in 1956 the terrorists expressed their 'deep regret' to the US government and explained that the bomb was meant for a Briton. 9 It was not until the late $1960 \mathrm{~s}$ that attacks on diplomats and their facilities were made a part of terrorist campaigns.

5 Between 1918 and 1968, for example, some 68 heads of state were assassinated. Bell, A Time of Terror, p.63.

6

James Eayrs, Diplomacy and its Discontents (University of Toronto Press, Toronto, 1971), p.10.

7 The Viet Cong attack on the US Embassy in Saigon during the 1968 Tet offensive hardly qualifies as a terrorist attack on a diplomatic facility, but is worthy of note as a deliberate attack by insurgents on a diplomatic mission for its symbolic value in a propaganda war.

8 Reproduced as Appendix 1 in Grivas, pp. 204-205.

9 wilson, p.54. 
While it is not possible to divide such complex phenomena into neatly defined periods, three very broad trends can be discerned in these sorts of terrorist attacks over the next fifteen years - kidnappings, embassy seizures and assassination attempts. Indiscriminate violence against diplomatic targets (usually in the form of bomb attacks) remained a feature throughout the period. The initial spate of kidnappings seems to have been a direct product of the collapse of rural-based insurgencies in Latin America. A member of the US Military Mission in Caracas was kidnapped by Venezuelan terrorists in 1963, and another in 1964, but no demands were made in either case and both captives were released unharmed after only a few days. Four years later two US Military Attaches in Guatemala were killed in what appears to have been an abortive kidnapping attempt. This was followed later in 1968 by the death of the US Ambassador to Guatemala, who was shot while attempting to escape his would-be terrorist kidnappers. It was in Brazil, however, that the tactic of abducting diplomats - 'diplonapping' was first used successfully by terrorists to win concessions from the receiving government. In September 1969 the US Ambassador, Charles Elbrick, was kidnapped in Rio de Janeiro by members of the Movimento Revolucionario do outubre 8 , a group associated with the ALN. ${ }^{10}$ For the Ambassador's safe return the terrorists demanded the release of fifteen political prisoners from Brazilian gaols and the publication of their political manifesto. ALN leader Carlos Marighela declared that:

By kidnapping the American Ambassador we wish to demonstrate that it is possible to triumph over the dictatorship and exploitation if we are properly armed and organised.11

\footnotetext{
10 The actual relationship between the Revolutionary Movement 8 October (MR-8) and the ALN is not clear. Peter Janke states that the Elbrick kidnapping was carried out by ALN militants 'in conjunction with' members of MR-8. Janke, p.438. See also note 11 .

11 Carlos Marighela, 'Declaration by the ALN October Revolutionary Group' in For the Liberation of Brazil (Penguin, Harmondsworth, 1971), p.25.
} 
The Brazilian government responded with massive searches and increased military controls over the population but soon agreed to the ALN's demands and the Ambassador was released without harm.

The success of this operation encouraged the Brazilian terrorists to try again. In March 1970 the Japanese ConsulGeneral in Sao Paulo was abducted and later released in return for five political prisoners. The following month an attempt to seize the US Consul in Porto Allegre failed, but in June the same year terrorists successfully kidnapped the FRG Ambassador to Brazil, Ehrenfried von Holleben. A communique left at the scene stated that 'the terrorists would no longer confine themselves to kidnapping representatives of the major powers: all foreign diplomats would be considered fair game'. 12 Von Holleben was later set free in return for the release of forty political prisoners. Only six months later, when the Swiss Ambassador to Brazil was kidnapped, the price of a diplomat's safe return had risen to seventy political prisoners, yet it was paid. As Robert Moss has correctly observed, it was 'runaway inflation'.13 It was also the successful manipulation of forces both within the Brazilian government and outside it, as explained by the leader of MR-8 in 1970 :

We orient our armed actions in such a way as to make them politically profitable. For instance, the kidnapping of a foreign diplomat creates political problems for the regime. Either the regime agrees with the Minister of Interior not to give in and allows the diplomat to be killed - which creates difficulties with the foreign power the diplomat represents, and with which the regime has economic ties - or the regime

\footnotetext{
12 Moss, p. 206.

13 op.cit., p.245.
} 


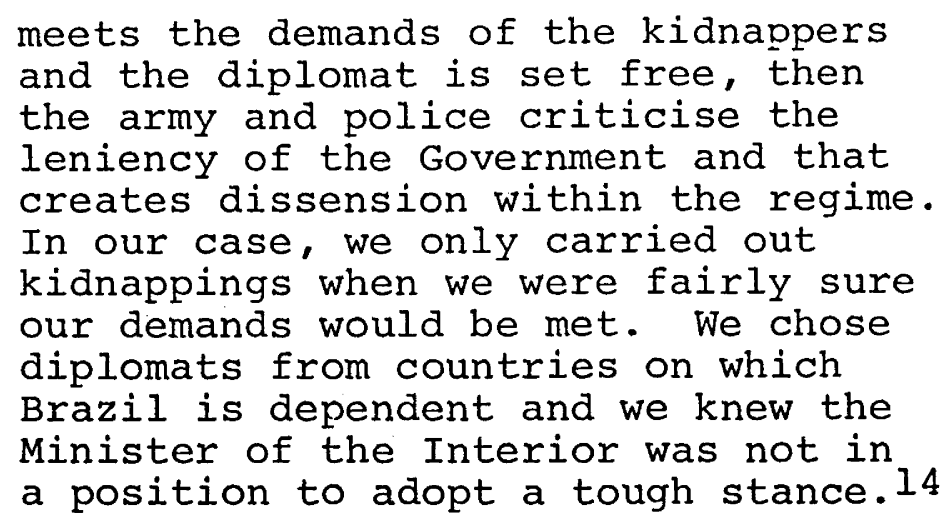

The success of the diplomatic kidnappings in Brazil ensured that the tactic would be quickly taken up by terrorist groups elsewhere. Between August 1968 and May 1971 there were no less than 21 kidnappings or attempted kidnappings of diplomatic personnel, in ten countries. All but four occurred in Latin America. ${ }^{15}$ Most of the hostages were released unharmed but three, the FRG Ambassador to Guatemala and a US AID Advisor in Uruguay in 1970, and the Israeli Consul-General in Turkey a year later, were killed by their captors after ransom demands were refused. After the death of the US AID Advisor, a terrorist is reported to have told a Cuban newspaper that the murder was necessary for the kidnappers to retain their credibility and 'because the success or failure of one urban guerrilla group in using diplomatic kidnapping as a form of political blackmail would influence other extremist movements that might be tempted to use the same weapon'. 16 The kidnapping and death of Count Karl von Spreti, the FRG Ambassador to Guatemala, was significant for other reasons. It was the first time that

\section{Quoted by Gramont, p.140.}

15 The four incidents which took place outside Latin America were the kidnappings of the US Political Secretary in Jordan in June 1970, the UK Consul in Canada in October 1970, the German Honorary Consul in Spain in December and the Israeli Consul-General to Turkey in May 1970. See the table in Baumann, p. 167 .

16 Moss, p. 228 . 
money had been demanded as part of the ransom, the first time that a diplomat had been killed by his captors and, perhaps most importantly, the first time that a sending government had publicly criticised the receiving government for its inability both to protect the diplomatic personnel for which it was responsible and to recover them safely in the event that they were abducted. The West German government sent a special envoy to Guatemala to press for accession to the terrorists' demands and after von spreti's murder reduced its diplomatic relations with the Guatemalan government to a bare minimum. FRG Chancellor Willy Brandt went as far as suggesting that concerted international action be taken to investigate this latest threat to diplomats, thus for the first time removing the entire problem 'from the realm of newspaper headlines to the realm of international law and politics'. 17

Diplomatic kidnappings reached a peak in 1970, when there were seventeen separate incidents. They then dropped away quickly until 1972 when the number began to rise again. According to the US State Department, diplomats from some 47 countries were kidnapped in the fifteen years between 1968-1983. 18 Personnel of all ranks were involved, including a number of Honorary Consuls, although a study conducted by the Rand Corporation in 1977 revealed that, of the 43 successful kidnappings carried out in the period August 1968June 1975, terrorists managed to abduct an Ambassador or at least a Consul-General 11 times. 19 From 1972, however, this tactic was overshadowed by an increased number of bomb attacks and seizures of diplomatic facilities.

\footnotetext{
17 Baumann, p.101.

18 Terrorist Incidents Involving Diplomats. p.4.

19 Brian Jenkins, Janera Johnson and David Ronfeldt, Numbered Lives: Some Statistical Observations From 77 International Hostage Episodes, Rand Paper P-5905 (Rand Corporation, Santa Monica, 1977), p.12.
} 
In 1955 six gunmen stormed the Romanian Legation in Berne and demanded the release of anti-communists from Romanian prisons, but this incident, like the seizure of the Yugoslav Consulate in Gothenburg by Croatian emigres in 1970, apparently failed to capture the imagination of the world's terrorists. 20 In December 1972, however, a significant new threat to diplomats emerged when the Israeli Embassy in Bangkok was seized by four members of the Black september Organisation (BSO), and its six occupants held hostage. The terrorists demanded the release of 36 Palestinian compatriots held in Israel but after 19 hours were persuaded by Thai authorities to free their captives in return for safe passage to Egypt. Less than three months later, eight members of the same terrorist group took control of the Saudi Arabian Embassy in Khartoum. They demanded the release of other Palestinians held in Israel and Jordan, and of members of the Red Army Faction imprisoned in the FRG. These demands were refused, but before surrendering to the Sudanese authorities the terrorists killed two us diplomats and a Belgian diplomat who had been in the Saudi Embassy at the time it was seized. In their tactics, the nature and scope of their demands, their ruthlessness and their use of one state's diplomatic assets to apply pressure on other states, these two terrorist attacks set a pattern for further seizures of diplomatic facilities in the years that followed.

Between 1972-1982 armed extremists took over embassies and consulates more than 50 times, 'generałly to demand the release of prisoners or other political concessions, sometimes just to register disapproval of a particular policy'.21 There was a dramatic increase in such incidents after 1979, due in part no doubt to the example provided by the hostage

20 B.M. Jenkins, Embassies Under Siege: A Review of 48 Embassy Takeovers, 1971-1980, Rand Report R-2651-RC (Rand Corporation, Santa Monica, 1981), pp.1-6.

21

Jenkins, Diplomats on the Front Line, p.3. 
crisis in Iran but also because of political struggles like that between Iraq and Iran, or that continuing in El Salvador. By the end of 1982 the diplomatic facilities of 38 countries had been seized by terrorists in at least 27 countries, with the missions of the United states and Egypt the most popular targets for this form of terrorist attack. 22 After 1981, however, the number of seizures each year declined as diplomatic facilities became more secure and as terrorists came to accept the limited results that such operations usually achieved. 23 Seizures of diplomatic facilities were not eliminated from the terrorists' tactical inventory, but were replaced as the most prevalent threat to diplomats by a greater frequency of personal attacks.

As both sending and receiving states began taking measures to guard against kidnappings and the seizure of diplomatic facilities, so terrorist groups turned increasingly to bombings and assassination attempts against specific targets. In 1970 about half the total number of international terrorist incidents were directed against people, half against property. By 1981 some 80 per cent of attacks were against people, and the proportion against diplomatic personnel seems to have risen accordingly. 24 Many attacks were made with handguns but bombs, always a favourite terrorist weapon, were responsible for many more casualties. Between 1968 and 1983 there were some 503 casualties in terrorist incidents involving

22 Jenkins, Embassies Under Siege, p.v and Perez, 'Terrorist Target: The Diplomat', p.2.

23 According to Brian Jenkins, embassy seizures were generally 'a losing proposition' for terrorists. Their demands were met less than 17 per cent of the time and one third of all terrorists involved in such operations were killed or captured. Jenkins, Diplomats on the Front Line, p.3. Of course, it could be argued that in terms of the publicity gained by the terrorists all such attacks were successful to a greater or lesser degree.

24

Patterns of International Terrorism: 1981, p.4. 
diplomats, and 1,315 wounded. 25 over the past few years attacks have become more destructive and less discriminating in their victims, with a greater number of people killed and wounded. 1983 saw a new development with the use by some terrorist groups of large car bombs driven to their targets by fanatics willing to martyr themselves in order to cause the greatest damage and highest number of casualties. The bombing of the US Embassy in Beirut in April 1983, for example, resulted in the death of 63 people, including 17 Americans, with 120 people injured. 26

As several noted scholars have shown, there are a number of serious obstacles to quantifying and evaluating trends of this kind. 27 The major difficulty, as always, lies in determining precisely what constitutes a terrorist attack. Another relates to the inevitable reliance of researchers on incomplete data bases and untested sources. While considerable efforts have been made by some collection agencies there will always be gaps in information about any clandestine activity. No figures can ever show the terrorist operations planned but never carried out, begun but aborted before they came to official notice and which may have taken place in closed societies and never publicly revealed. Even compilations in the same country with access to many of the same sources, like those of the US State Department and the Rand Corporation, differ markedly in some crucial areas. 28 Figures can in any case provide only part of the picture, as terrorist attacks also need to be judged in terms of their

\section{Terrorist Incidents Involving Diplomats, p.3.}

26 'Victims of Terrorism', Department of State Newsletter (May 1983), p.2. See also Terrorist Bombings: A Statistical overview of International Terrorist Bombing Incidents from January 1977 through May 1983 (State Department, Washington, 1983), p.1.

27 Wardlaw, Political Terrorism, pp.50-53, Bell, 'Terror:

An Overview' in Livingston, pp.41-42 and Jenkins, Diplomats on the front Line, pp.1-2.

28 This is demonstrated best by Wardlaw, Political Terrorism, pp.50-53. 
effects. With all these problems in mind, it is nevertheless still possible to survey the levels of terrorist attacks on diplomats and diplomatic facilities over the past fifteen years and make some general observations. 29

Between 1968-1982 the Rand Corporation recorded 574 attacks against diplomats and diplomatic facilities, in total more than 25 per cent of all international terrorist attacks for the period. 30 By 1983, the level of attacks agrainst diplomatic targets had risen to nearly 40 per cent of the total. 31 The us state Department, which includes threats, hoaxes, arms smuggling incidents and other kinds of terroristrelated data in its statistics, has reckoned that the level of attacks against diplomatic targets between 1968-1983 stood at 52 per cent of the total. 32 Both collection agencies agree that the number of attacks against diplomats and diplomatic facilities grew steadily almost every year, jumping dramatically to reach a peak in 1980. On present indications, 1984 seems likely to have recorded a level of incidents at least as high and probably higher than at any time since these records were begun in 1968. 33

29 Both the Rand Corporation and State Department have compiled their statistics from 1 January 1968. Both being American agencies, it would be surprising if they did not show some bias in their figures, if not from ideological or other political reasons, then from the sources at their disposal. 30 Jenkins, Diplomats on the Front Line, p.1.

31 B.M. Jenkins, New Modes of Conflict, Rand Report R-3009-DNA (Rand Corporation, Santa Monica, 1983), p.14.

32 Terrorist Incidents Involving Diplomats, p.I and R.M. Sayre, 'International Terrorism: A Long Twilight'struggle', Address by Robert M. Sayre, Director of the Office for Counterterrorism and Emergency Planning, before the Foreign Policy Association, New York, 15 August 1984, Current Policy 608 (15 August 1984), p.1.

33 Jenkins, New Modes of Conflict, p.16. See also Brian Jenkins' predictions quoted in 'Embassies Under Seige', Newsweek (11 December 1984), p.146 and Sayre, p.l. 
Not only are terrorists attacking diplomatic targets more often but they are attacking the diplomats of more states. To date terrorists have carried out operations against the personnel and premises of at least 66 states $^{34}$ with ten nationalities the targets in more than half the incidents. Those states most threatened with this kind of violence have been the United States, Turkey and Yugoslavia, followed by France, Cuba, the Soviet Union and the United Kingdom. 35. Attacks are taking place in more countries, although 42 per cent of all incidents have occurred in North America and Western Europe, with most of the remainder in Central America and the Middle East. The most favoured location for terrorist attacks against diplomats is the United States (particularly New York) ${ }^{36}$ followed by France, Lebanon, El Salvador, Guatemala, Argentina, Colombia, Italy and the FRG. 37 According to the state Department, 460 attacks on diplomats or against diplomatic facilities between January 1968-April 1983 resulted in deaths or personal injuries. 38

34 Jenkins, Diplomats on the Front Line, p.4. With its wider data base, the US State Department lists incidents involving the diplomats of 113 countries. See Terrorist Incidents Involving Diplomats, p.3.

35 In 1982 it was estimated that US diplomats were the intended victims in 29 per cent of all international terrorist attacks since 1968. See Jenkins, Diplomats on the Front Line, pp.4-5 and Terrorist Incidents Involving Diplomats, p. 3 .

36

Half the terrorist attacks on diplomats in the United States have taken place in New York and have involved diplomatic missions to the United Nations. Only 20 per cent of the attacks in the US took place in Washington, with the remainder scattered throughout the country, reflecting the distribution of various ethnic communities and minor diplomatic posts. Jenkins, Diplomats on the Front Line, p.6. See also the report prepared by the State Department's Threat Analysis Group dated 2 April 1984 and entitled 'Terrorist Attacks Against Diplomatic Installations and Personnel in the US'. This report was reproduced in the Hearings of the US House of Representatives Appropriation Committee: Budget Explanation: State Department FY 1984: Request for Protection of Foreign Missions and Officials in the US (1984).

37 Jenkins, Diplomats on the Front Line, p.6 and Terrorist Incidents Involving Diplomats, p.3. 
The State Department has listed some 102 groups claiming responsibility for attacks on diplomatic targets over the last fifteen years. 39 The number is increasing each year and many of the new terrorist groups appear to be singling out diplomats as one of their primary targets. The motives for these attacks are almost as diverse as the groups responsible. While several attempts have been made to devise typologies for such incidents the most useful is perhaps that suggested by Brian Jenkins in Diplomats on the Front Line, published in 1982. In that study he identified five major types of terrorist attack involving diplomats, as follows: ${ }^{40}$ terrorist attacks on diplomats that are associated with current insurgencies, such as those in Central America. This is one of the largest categories: attacks by ethnic, emigre or exile groups against the representatives of the state they oppose, such as those carried out by croatian separatist groups against Yugoslav diplomats and diplomatic missions: worldwide attacks on foreign diplomats by terrorists operating as part of a wider campaign against a government, such as those conducted by various palestinian and Irish groups: isolated terrorist attacks against diplomats by indigenous groups to protest the actions of a foreign government, one example of which would be the bombing of the French Embassy in Lima to protest against French nuclear tests in the Pacific: and finally, the government use

\section{Terrorist Incidents Involving Diplomats, p.5. Once again, the state Department warns that some claims may be false and that some groups may have been invented to disguise the involvement of states or organisations in particular incidents. The State Department's list is reproduced as Appendix D of this thesis.}

40 The following paragraph draws heavily on the typology expounded by Brian Jenkins in his study of Diplomats on the Front Line, pp.8-10. This manner of categorising terrorist attacks against diplomatic targets has also been followed by at least one international conference on the subject. See J.F. Murphy, 'Report on Conference on International Terrorism: Protection of Diplomatic Premises and Personnel, Bellagio, Italy, 8-12 March 1982' in Terrorism: An International Journal 6:3 (1983), pp.483-484. 
of terrorist tactics, or employment of terrorist groups to attack foreign diplomats abroad as the continuation of a local armed conflict, or as a form of surrogate warfare. The rash of attacks by Iran and Iraq against each other's diplomats since the war between the two countries began in 1980 would fall into this category.

No terrorist group concentrates exclusively on attacks against diplomats or diplomatic facilities, but a number have given a high priority to these targets. Since their latest terrorist campaign began in 1975 Armenian separatists, for example, have carried out more than 70 attacks on Turkish diplomats, resulting in the death of some 43, including members of their families. 41 various Croatian groups too have singled out diplomatic targets for special attention, although in their case their attacks have been directed against Yugoslav officials and facilities. In 1973 Australian police seized a confidential booklet, probably produced by the Hrvatsko Revolucionario Bratsvo 42 and entitled 'Instructions for Croats Outside Their Homeland', which exhorted Croatian extremists to:

Destroy all Yugoslav embassies and consulates, kill Yugoslav diplomatic representatives because they are
common criminals and Fascists. 43

41 'The New Terror Network', Newsweek (12 February 1985), p.112. This figure is considerably higher than other estimates (The Australian of 13 December 1984, for example, cites 26), but includes the victims of attacks in 1973 and 1974, and counts family members. See also Andrew Corsun, Armenian Terrorism: 1975-1980, Research Papers on Terrorism, Office of Security Threat Analysis Group, US Department of State (State Department, Washington, n.d.) and 'Terrorism: The Turkish Experience', Hearing before the Subcommittee on Security and Terrorism of the Committee on the Judiciary, US Senate, 97th Congress, First Session, 25 June 1981.

42 Croatian Revolutionary Brotherhood, or HRB. This group was apparently 'neutralised' for a time but re-emerged in Australia as the Hrvatska Ilegalna Revolucionarna Organizacija or Croat Illegal Revolutionary Organisation (HIRO), before reverting to its original name. See Stephen Clissold, Croat Separatism: Nationalism, Dissidence and Terrorism, Conflict Studies 103 (Institute for the Study of Conflict, London, 1979), p. 15 . 
A number of anti-Castro Cuban groups and various Palestinian groups have also singled out diplomatic targets for attack, as have Jewish extremist organisations active in the United States and Western Europe. In 1974 a number of Latin American terrorist groups established a Junta de Coordinacion Revolucionaria in Paris, one of the main purposes of which was to facilitate the assassination of Latin American diplomats in Europe. 44 Diplomatic targets are still popular with extremists in Latin America itself.

Despite some superficial similarities, these terrorist attacks are in many ways unique, arising from and taking place in circumstances that can never be repeated. Yet here again some general observations can be made. Diplomats and diplomatic facilities might be chosen as primary or instrumental targets, ${ }^{45}$ attacked either because of their immediate value to the terrorists (such as the assassination of the British Ambassador to Ireland in July 1976 by the IRA) or because they may be used as a means to induce certain responses in other governments, as was the case when members of Colombia's Movimiento 19 Abri 46 occupied the Dominican Embassy in Bogota in February 1980 and used the 18 high ranking diplomats captured there at the time to bargain with the Colombian government. 47 often, elements of both are present. 48 In these ways, terrorists have been able to

\section{4} p. 228 .

Junta of Revolutionary Coordination. Laqueur, Terrorism 45 46 Murphy, in Evans and Murphy, p.280.

April 19 Movement, or M-19.

47

When M-19 attacked the Dominican Embassy a reception was being held, attended by the Ambassadors of the United States, Mexico, Austria and seven other countries, including the Papal Nuncio. The terrorists demanded the release of 311 political prisoners, a US\$50 million ransom and safe conduct out of the country. See F.J. Hacker, 'A Case Study of Hostage Negotiation' in Herz, pp.1-5.

48

B.M. Jenkins, 'International Terrorism: Conflict' in Carlton and Schaerf, pp.16-18.

A New Mode of 
register protests against particular states and win various concessions, such as the release of political prisoners, the publication of political statements or simply additional operating funds. In some cases terrorist actions against diplomats have prompted responses by states that have either been repressive, and thus counter-productive, or else of such a nature as to threaten the very liberties which the states claim to defend. 49 Attacks have embarrassed receiving governments by exposing their inability to protect diplomats and their facilities and in other ways caused friction with the sending states. The latter in their turn have been obliged to divert resources to protect their missions abroad and have suffered additional uncertainties in the conduct of their international relations. These victories for the terrorists, however, have been largely tactical. The real value of diplomatic targets for terrorist groups lie in their ability to promote wider strategic objectives.

Diplomats and diplomatic facilities are uniquely valuable targets for any terrorist group. After centuries, the diplomat is now 'the most purely representative figure of his time. Behind him stands his whole country and its aims ... He is the point of contact between policy and the world outside'. 50 By attacking one official or one office a terrorist group which is not structurally or logistically equipped for a larger scale war can in effect assault an entire state, group of states or world system in miniature.

49 Obvious examples of the first include the massive repression that followed terrorist actions in Brazil and Uruguay. The second category could arguably include the overwhelming military responses to incidents in Canada in 1970 and Australia in 1978. Grant Wardlaw has recently argued for greater caution in state responses, with particular attention to the British effort against the IRA, in 'Terrorism, CounterTerrorism and the Democratic Society', draft chapter prepared for inclusion in Michael Stohl and G.A. Lopez (Eds), State Terrorism: New Perspectives for Research (forthcoming). 50 1981), p.35. 
Terrorists can attack a policy, an alliance or a world view. Thus the American Ambassador kidnapped in Brazil in 1969 represented the 'big North American capitalists' 51 and the British Ambassador kidnapped by Tupamaros in Montevideo in 1971 was seen as a symbol of 'British imperialism'. 52 Soviet missions have been attacked because they represent the communist system and US missions because they represent the capitalist system. Egyptian missions have been seized because Egypt supported the Camp David Accords and Saudi Arabian missions have been bombed because that country supported Western peace initiatives in Lebanon. Yugoslav diplomats have been assassinated because their government denies Croatians a separate state of their own and Turkish officials are threatened because of what a Turkish government did to the Armenian population over 70 years ago. Because of their uniquely representative function diplomats and diplomatic facilities are seen as potent symbols through the manipulation of which terrorists can seize the initiative in a psychological war.

Such attacks also ensure the terrorists of an immediate and wide response. By openly flouting the time-honoured principle of diplomatic inviolability terrorists 'automatically engage the attention and concern of the entire diplomatic community as well as the states directly involved'. Just as importantly, the blatant contravention of such wellestablished legal and ethical norms gives the terrorists' actions additional shock value, which in turn guarantees them

51 Carlos Marighela, 'On the Organisational Function of Revolutionary Violence' in For The Liberation of Brazil, p. 38 .

52 Bell, A Time of Terror, p.55. Sir Geoffrey Jackson's account of his capture and eight-month imprisonment is given in People's Prison (Faber, London, 1973).

53 Baumann, p.110. 
greater publicity. For, as one observer has noted, 'terrorism is theatre ${ }^{54}$ and targets are chosen in large part because of the attention they are likely to attract in the international news media. Even after fifteen years of such incidents the murder of a diplomat is still considered newsworthy, as was demonstrated in November last year when world attention was focussed on the assassination of a middleranking British official in a minor diplomatic post in India. 55 Should public interest begin to wane more spectacular operations, such as the car bomb attacks on diplomatic missions in Beirut in 1983 and 1984 can quickly regain the world's attention. 56

All these factors have combined to make diplomatic targets peculiarly attractive to terrorist groups and seem assured to keep diplomats and their facilities in the 'front line'. Yet in recent years another reason has been suggested for the increased number of attacks on diplomatic targets. This is the use of terrorist tactics, and the employment of terrorist groups, by established states to attack the diplomats of other states abroad, either as an extension of a particular foreign policy or as a form of surrogate warfare.

54 Brian Jenkins, quoted in Philip Schlesinger, Graham Murdock and Philip Elliott, Televising Terrorism: Political Violence in Popular Culture (Comedia, London, 1983), p.12.

55 on 27 November 1984 Percy Norris, the British Deputy High Commissioner in Bombay, was being driven to the UK Consulate when two men shot him as his car stopped at a traffic light. The following day a man calling from Bucharest, Romania, informed European news agencies that the murder had been carried out by the 'Revolutionary Organisation of Socialist Muslims', a group believed responsible for the shooting of the Israeli Ambassador to Britain in June 1982 and the death of another British diplomat in Athens in March 1984. See 'Embassies Under Siege', Newsweek, p.149.

56

A number of studies have examined the relationship between the media and terrorist violence. See for example Richard Clutterbuck, The Media and Political Violence (Macmillan, London, 1981) and 'Terrorism and the Media: A Special Issue', Terrorism: An International Journal 2:1 and 2 (1979). 


\author{
Chapter III \\ THE COMPLICATION \\ State-Sponsored Terrorism
}

How should you govern any kingdom That know not how to use ambassadors?

William Shakespeare

King Henry VI, Part 3

(16th Century)

The growing scope and complexity of international terrorism, particularly the threat to diplomats and diplomatic facilities, has caused widespread concern among members of the international community and prompted a lively debate on the measures appropriate for their protection. Consideration of this matter, however, has been greatly complicated not only by differing interpretations of the nature of terrorism but by the involvement of states themselves in terrorist activities.

Once again, this problem is not new but since the 1960s, when terrorism emerged as a coherent doctrine of revolutionary warfare and a myriad groups sprang up around the world to capitalise on the increased vulnerability of modern society, the involvement of governments in terrorism has been given considerable attention. The debate over this matter has been heightened by the open admission of some states that they were prepared to sponsor terrorist groups as a means of extending their foreign policy options and by the Reagan Administration's insistence that terrorism has become a global issue with the potential to destroy diplomacy, 
undermine world stability and threaten civilisation itself. ${ }^{1}$ In taking these extreme positions, both sides have drawn attention to the breakdown of the international system which has prevailed since 1945, in which the two great powers and their allies could indulge in terrorist activities of all kinds without upsetting the basic framework of world order which they established as a victorious alliance at the end of the Second World War. With the emergence of other states less prepared to acquiesce in this system and independent groups active outside it the ability of the great powers to control events has greatly diminished, thus adding to the general uncertainty of international relations and in particular to the insecurity of the United States in the face of growing soviet power. In such a situation diplomacy can play a crucial role yet paradoxically the sponorship of terrorist groups by some states has also challenged the principles on which that institution is based.

The problem of state involvement in terrorist activities, in particular those relating to diplomacy, can be approached at three levels. The first level is that at which encouragement - either active or passive - is given by governments to groups or mobs which threaten diplomats and diplomatic facilities within their own national boundaries. The second level is that of support-either direct or indirect by a government for terroristsoperating in other states, while the third is that at which states actually conduct terrorist operations themselves, either using their own operatives or by enlisting terrorist groups directly to act on their behalf.

1 This is a recurring theme in statements made by members of the Reagan Administration. See in particular G.P. Shultz, 'Terrorism: The Challenge to the Democracies', Address by the Secretary of State before the Jonathan Institute's Second Conference on International Terrorism, Washington, 24 June 1984 . Reprinted in Current Policy 589 (24 June 1984), pp.2-3. 
There have been innumerable cases in the past where governments have knowingly failed to show respect, or provide protection for diplomats and diplomatic facilities for which they were responsible under international law. It is not the place here to investigate the record of harassment, insult or minor injury suffered by diplomats at the hands of state officials, nor is it appropriate to survey the long history of violations of diplomatic premises and communications. Yet it is useful briefly to consider some instances of government complicity in attacks on diplomats and their facilities by violent mobs. ${ }^{2}$ Perhaps the first and most celebrated instance this century occurred in 1900 when the Chinese Empress Dowager formed a loose alliance with a rebellious coalition of soldiers and millenarian elements to besiege the Peking Legation Quarter for 55 days. ${ }^{3}$ A comparable wave of anti-foreign sentiment arose in China during the Cultural Revolution in 1966-1967, when Red Guards assaulted the diplomats of several states and attacked a number of missions. The British Embassy was burnt down by a violent mob and over 20 serious violations of diplomatic immunity recorded. These attacks were made with the knowledge of the Chinese authorities who did nothing to prevent or stop them. In reply to formal protests from the diplomatic community the Chinese Foreign Ministry reportedly refused assistance and declared that 'diplomatic immunity is a product of bourgeois norms'. 4

2 It is worthy of note that the receiving state retains its formal responsibilities for the protection of diplomatic missions, and they their inviolability, even in the case of an irreparable breach in relations between the sending and receiving states, even war. Thus diplomats and diplomatic facilities are entitled to protection from violent mobs regardless of any differences that might be at issue between the two states at the time. See Article 44 of the Vienna Convention in Appendix E.

3

Giles, passim.

4

Quoted in Boyce, p.207. Ironically, while the Chinese Foreign Ministry was rejecting requests for protection from the diplomatic community in Peking, the Burmese government called out armed troops to protect the Chinese Embassy in Rangoon from a violent mob which had attacked it, killing one Chinese diplomat. See Ralph Pettman, China in Burma's Foreign Policy. Contemporary China Papers 7 (Australian National University Press, Canberra, 1973), pp.31-34. 
There were also a number of violent attacks on diplomatic missions in Indonesia during the 1960s, most of which were clearly carried out with the approval of the local authorities. In 1963, for example, the British and Malaysian Embassies in Jakarta were sacked and a number of diplomatic staff injured by mobs protesting against the formation of the Malaysian Federation. ${ }^{5}$ The Suharto regime inspired or at least condoned a number of attacks on Chinese diplomatic personnel and facilities between 1965-1970 and probably had a part in attacks on two Us consulates in Indonesia during the same period. ${ }^{6}$ on all these occasions requests for protection from the diplomatic community were refused. The tactic of exploiting violent mobs to register grievances against another governemnt has also been demonstrated by the cambodians. In 1965 a large crowd attacked the US Embassy in Phnom Penh with the obvious knowledge of Prince Sihanouk's Administration. In 1970, shortly after the Prince was deposed by Lon Nol in a military coup, a similar attack was made against the Embassy of the North Vietnamese. The same year, the Chinese and DPRK Ambassadors to Cambodia were held hostage by the Lon Nol Government pending the safe evacuation of Cambodian diplomatic staff from Pyongyang and Peking. 7 In 1979 the Us Embassies in Tripoli and Islamabad were both stormed by mobs instigated by the local governments. Other examples abound. 8

5 In return, the Indonesian Embassy in Kuala Lumpur was sacked by a Malaysian mob and three Indonesian diplomats seized as hostages. These incidents are described in detail in J.A.C. Mackie, Konfrontasi: The Indonesia-Malaysia Dispute 1963-1966 (Oxford University Press, Kuala Lumpur, 1974), pp. 181-193.

6

Boyce, p. 203.

7 ibid.

8 Between 1970 and 1980 'there were some 70 forcible incursions into diplomatic facilities'. Fifty per cent occurred after the Iranian hostage seizures. Perez, 'Terrorist Target: The Diplomat', p.2. 
Because of the international repercussions of obvious state complicity in such attacks the fiction is usually maintained that they occurred either without the knowledge of the local authorities or that the security forces of the receiving government had been unable to prevent them. 9 In many cases where mob violence was serious official apologies were later offered and in some cases, like that of the British Embassy burnt down in Peking, reparations were made to the sending state. Thus the seizure of the US Embassy in Tehran in November 1979, and the holding of its American occupants for over a year, ${ }^{10}$ shocked the international community not so much because Iran had signally failed to protect them - that had happened often enough before - but because the regime of the Ayotollah Khomeini openly 'adopted' the attack as its own. ${ }^{1}$ As US President Jimmy Carter later wrote of the seizure:

9 Receiving states are bound by the Vienna Convention on Diplomatic Relations to protect diplomatic personnel, according to Sen even against the expression of 'hostile views, contempt or even disapprobation of a foreign state'. Sen, pp.97-98. States are also obliged by international law to exercise 'due diligence' to prevent the commission on their territory of certain acts by private persons to other states, or their representatives. J.L. Brierly, The Law of Nations (Oxford University Press, Oxford, 1984), p. 289 .

10 There were 100 people in the US Embassy compound when it was seized on 4 November 1979 . The 34 locally-engaged staff members were immediately allowed to go and after two weeks the $13 \mathrm{black}$ and female Americans held hostage were also permitted to leave. One other member of the Embassy staff was released because of illness in July 1980, leaving 52 hostages held for the 444 days of the 'crisis'. They were finally released on 21 January 1981. A detailed chronology of these events is given in Pierre Salinger, America HeldHostage: The Secret Negotiations (Andre Deutsch, London, 1981), pp.311-319.

11 There had been one earlier example of a state openly embracing terrorists on its own soil (though not for a terrorist act committed within its own borders). Ugandan President Idi Amin clearly supported the Palestinian terrorists who hijacked an Air France Airbus and flew it to Entebbe Airport in June 1976. See William Stevenson, 90 Minutes at Entebbe (Corgi, London, 1976), p.ix. 
We were deeply disturbed, but reasonably confident that the Iranians would soon remove the attackers from the embassy compound and release our peorle. We and other nations had faced this kind of attack many times in the past, but never, so far as we knew, had a host government failed to attempt to protect threatened diplomats. 12

Both the Iranian Prime Minister and Foreign Minister had given the US a firm pledge that US staff and property would be protected, but in blatant disregard of these undertakings, traditional custom, international law and world opinion the militants who had stormed the US compound were subsequently given official blessing.

While strictly speaking assaults on diplomats and diplomatic facilities of this kind do not constitute statesponsored terrorism as defined earlier, they are nevertheless a form of symbolic attack by one state upon another through the agency of non-state actors. In demonstrating the receiving state's displeasure and applying pressure for policy changes they act as an extension of that state's foreign policies and as such have been included in Herman Kahn's controversial analysis of the progressive intensification of political conflict. 13 These attacks also highlight the fragility of diplomatic conventions and are illustrative of the failure of some states to observe the customary rules regarding the protection of diplomats and their facilities. By extension, they suggest too that such international instruments can never be sufficient in themselves to commit states to the peaceful settlement of disputes and restrain them from other forms of attack on diplomatic targets.

12 Jimmy Carter, Keeping Faith: Memoirs of a President (Bantam Books, Toronto, 1982), p.457.

13 Herman Kahn, On Escalation: Metaphors and Scenarios (Penguin, Baltimore, 1968), p.73. 
covert or indirect foreign intervention. 17 Few of the states sponsoring particinants in these struggles appear to have been particularly concerned about the tactics used and in a number of cases were themselves directly involved in terrorist operations. 18 By the late 1960s, however, many insurgent groups were turning to tactics of a different kind. At the same time there arose a number of groups without any specific national or political constituency and whose ideologies contained a significant nihilistic element. International diplomatic support was no longer prized and such restraints on action as had existed before well nigh disappeared. The sponsorship of such groups involved states in the hijacking of aircraft, kidnappings, assassinations and indiscriminate violence against civilian targets. It also deeply implicated them in attacks on diplomats and diplomatic facilities. The international scope of these attacks, their apparent lack of rationale and popular support, and in particular their targets, separated modern terrorists from other insurgent groups and made government support a more sensitive issue.

It is easy to find lists of countries accused of sponsoring international terrorism, but with few exceptions these tend to be compiled by Western observers concerned exclusively with agitational terror which is felt to serve the interests of the Eastern bloc. Thus Brian crozier of the London-based Institute for the Study of Conflict told a

17 Wilkinson, Terrorism and the Liberals tate, p.177. wilkinson claims that less than 10 per cent of the internationally significant outbreaks of violence since 1945 were direct military conflicts.

18 One of the more publicised recent examples of this involvement is the participation of Americans in the selective assassination of Vietnamese civilians under the Phoenix Program in South Vietnam after 1968. While the subject of considerable controversy, this participation has been confirmed by CIA operatives working in Vietnam at the time. See Michael Maclear, Vietnam: The Ten Thousand Day War (Thames Methuen, London, 1981), p.255. 
subcommittee of the US Senate in 1975 that the Soviet Union and its Eastern European satellites, the Peoples Republic of China, the DPRK, Vietnam, Cuba, Algeria, Tanzania, Zambia, Congo (Brazzaville) and Zaire, the Peoples Democratic Republic of Yemen (PDRY), Iraq, Syria and Libya were all 'subversive centres'. 19 Other Western commentators and government spokesmen have since added Lebanon, Iran, Uganda, Somalia and Egypt. 20 The US state Department has also compiled a list of 24 countries, including Mexico and Chile, which it claims has offered political asylum to known terrorists. 21 Yet such lists must be treated with caution. They can be greatly lengthened or drastically reduced, depending on the definition of terrorism used and the ideological persuasion of the person or agency compiling them. There is immense room for the application of double standards. No Western list, for example, includes the names of those countries which provide aid to regimes which depend on enforcement terror to maintain power and can thus be accused of 'surrogate terrorism'.22 Rarely are countries like Saudi Arabia, Greece or even Australia mentioned despite their past tolerance of and even support for certain terrorist groups. 23 Too often countries like China, Egypt and Jordan

\section{9 'Terrorist Activity: International Terrorism', Hearings before the Subcommittee to Investigate the Administration of the Internal security Act and other Internal Security Laws of the Committee of the Judiciary, US Senate, 94 th Congress, First Session, Part 4, 14 May 1975.}

20 See for example D.M. Trent, A National Policy to Combat Terrorism, Hoover Institution on War, Revolution and Peace, Reprint Series 22 (Stanford University, Stanford, 1979), p.2.

21 Patterns of International Terrorism: 1981, p.2.

22 stohl, 'National Interests', p.51.

23 Yugoslavia has exerted considerable pressure on the Australian government in the past for its tolerance of, and alleged financial support for, Croatian extremist organisations. Clissold, pp.12-13. It is suspected that since the Turkish invasion of Cyprus, Greece has given assistance to Armenian terrorist groups. 
are left off the West's lists because of current political sensitivities - a consideration that has now apparently been extended to Iraq. 24 support for groups like the Contras in Nicaragua or the mujahideen in Afghanistan is ignored while comparable Eastern bloc support for insurgent groups in Central America is included. Clandestine operations by Western intelligence services are overlooked while those of the West's adversaries are not.

Even if consideration of this problem was confined to those states which have given support to insurgent terrorists over recent years, it would be difficult to be specific. Because of its largely clandestine nature, the extent of this assistance is hard to determine. It covers a wide range of activities and is constantly changing. It would appear, however, that the Soviet Union, its Eastern European satellites and a number of radical Arab states in particular have provided considerable amounts of arms, funds, training and logistical support, both directly and through intermediaries. A conference on 'International Terrorism: Protection of Diplomatic Premises and Personnel' held in 1982 was told that the Palestine Liberation Organisation had an annual budget of US\$250 million, some of which was distributed to other terrorist groups. 25 Colonel Qaddafi's support for a wide range of terrorist organisations since the mid-

24 The omission of Iraq from such lists is apparently 'diplomatic bait' to encourage more moderate behaviour. Murphy, 'Report on Conference', p.496.

25 Murphy, 'Report on Conference', p.484. Such figures can be very misleading if used without care, as has been done, for example, in Christopher Dobson and Ronald Payne, The Weapons of Terror: International Terrorism at Work (Macmillan, London, 1979), pp.82-83. Even after the PLO has used a large proportion of these funds for its own operating expenses, including the cost of running its own 'diplomatic' service, it has substantial amounts to pass on to other groups such as the IRA, the African National Congress (ANC), and the Fuerzas Armadas de Liberacion Nacional (the Puerto Rican separatist group responsible for a number of incidents in the US). These funds pale into insignificance, however, compared with some of the ransoms paid to some Latin American groups. It has been estimated that between $1968-1980$ over US $\$ 250$ million was paid as ransom to terrorists by multinational companies alone. See 'International Terrorism', Address by the Head, Protective Services Coordination Centre, to the Joint Services Staff College, Canberra, 22 February 1983, p.10. 
are left off the West's lists because of current political sensitivities - a consideration that has now apparently been extended to Iraq. 24 support for groups like the Contras in Nicaragua or the mujahideen in Afghanistan is ignored while comparable Eastern bloc support for insurgent groups in Central America is included. Clandestine operations by Western intelligence services are overlooked while those of the West's adversaries are not.

Even if consideration of this problem was confined to those states which have given support to insurgent terrorists over recent years, it would be difficult to be specific. Because of its largely clandestine nature, the extent of this assistance is hard to determine. It covers a wide range of activities and is constantly changing. It would appear, however, that the Soviet Union, its Eastern European satellites and a number of radical Arab states in particular have provided considerable amounts of arms, funds, training and logistical support, both directly and through intermediaries. A conference on 'International Terrorism: Protection of Diplomatic Premises and Personnel' held in 1982 was told that the Palestine Liberation organisation had an annual budget of US\$250 million, some of which was distributed to other terrorist groups. 25 Colonel Qaddafi's support for a wide range of terrorist organisations since the mid-

24 The omission of Iraq from such lists is apparently 'diplomatic bait' to encourage more moderate behaviour. Murphy, 'Report on Conference', p.496.

25 Murphy, 'Report on Conference', p.484. Such figures can be very misleading if used without care, as has been done, for example, in Christopher Dobson and Ronald Payne, The Weapons of Terror: International Terrorism at Work (Macmillan, London, 1979), pp.82-83. Even after the PLO has used a large proportion of these funds for its own operating expenses, including the cost of running its own 'diplomatic' service, it has substantial amounts to pass on to other groups such as the IRA, the African National Congress (ANC), and the Fuerzas Armadas de Liberacion Nacional (the Puerto Rican separatist group responsible for a number of incidents in the US). These funds pale into insignificance, however, compared with some of the ransoms paid to some Latin American groups. It has been estimated that between 1968-1980 over US\$250 million was paid as ransom to terrorists by multinational companies alone. See 'International Terrorism', Address by the Head, Protective Services Coordination Centre, to the Joint Services Staff College, Canberra, 22 February 1983, p.10. 
1970s is now well established and often proudly admitted. The Libyan Secretary of Information, for examnle, was reported to have stated in 1980 that:

We are proud to be used ... We assert to the whole world that we provide material, moral and political support to every liberation revolution in the world. 26

Such boasts need to be treated carefully. As William Gutteridge has reminded observers, 'the tireless fanaticism attributed to the Libyan leader can easily be overdrawn', 27 yet Libya has certainly been extraordinarily generous in the provision of funds, facilities and material support to international terrorists. 28 Iran has usually been less open about its aid to terrorist groups but probably wider in its reach, giving support to groups in Europe, the Midale East and Asia. The PDRY and DPRK appear to have concentrated their efforts on the provision of training facilities and since 1964 are reputed to have trained thousands of terrorists from around the world. 29 Cuba too is reported to have been lavish in its support for terrorist groups in Latin America, both in its own right between 1960-1968 and on behalf of the Soviet Union after that time. 30

26 Quoted in Cline and Alexander, p.69.

27 William Gutteridge (Ed), Libya: Stizl a Threat to Western Interests? Conflict Studies 160 (Institute for the Study of Conflict, London, 1984), p.3.

28 Gutteridge, pp.3-6. See also 'Libyans Arm and Train World Terrorists', New york Times 16 July 1976, pp.Al-A6. Colonel Qaddafi is reputed to have paid the international terrorist known as 'Carlos' US\$2 million for his attack on the OPEC Ministers' meeting in Vienna in December 1975.

29 David Rees, North Korea's Growth as a Subversive Centre, Conflict Studies 28 (Institute for the Study of Conflict, London, 1972), Patterns of International Terrorism: 1981, p.21, and Shultz and Sloan, p.204.

30 'The Role of Cuba in International Terrorism and Subversion', Hearings before the Subcommittee on Security and Terrorism of the Committee on the Judiciary, Us Senate, 97th Congress, 26 February-12 March 1982. See also Sterling, p.247. 1968 is the year the Soviet $\mathrm{KGB}$ is reputed to have taken control of its Cuban counterpart, the Direccion General de Intelligencia (DGI). 
Not only are states providing increasing support for international terrorist groups, but they are becoming directly involved in terrorist operations. Often groups are enlisted to conduct attacks on behalf of a state and there is apparently a growing trend in the use of official personnel directly to carry out terrorist attacks. Most states have carried out covert intelligence operations before, a category which has included kidnappings and assassinations, 31 but rarely have they participated in a concerted campaign of international terrorist violence. Once again, Libya has been most open about its activities, with public threats against its critics abroad and, particularly after the Gulf of Sirte incident in August 1981, 32 against United States officials anà offices abroad. A number of Libyan 'hit teams' have been sent to assassinate American diplomats in Europe and efforts to assassinate the US Ambassador to Egypt are well documented. 33 other 'hit teams' have successfully murdered a number of Libyan exiles in several different countries. Despite widespread condemnation of these practices and the deportation of some of the Libyans involved there is no sign that Libya's support for these 'suicide commandos' will ease in the near future. ${ }^{34}$ Iran too has been directly

31 There has been a recent spate of books dealing with this subject, among them John Barron's KGB: The Secret Work of Soviet secret Agents (Transworld, London, 1975), The CIA and the Cult of Inteliigence (Del1, New York, 1975) by Victor Machettti and J.D. Marks, and Philip Agee, Inside the Company: CIA Diary (Penguin, Harmondsworth, 1975). While there is considerable controversy over the apparent revelations in such works, there seems little doubt that the covert operations of these (and other) intelligence services have included assassinations and kidnappings, and other activities now associated with terrorist groups.

32 In 1973 Libya insisted that the Gulf of Sirte was entirely Libyan territory. Almost as soon as he was inaugurated, President Reagan announced that the Sixth Fleet's summer manoeuvres would be held in the Gulf, within the area claimed by Colonel Qaddafi. When they took place in August 1981, Libyan jets converged on the US Fleet and two were shot down. Gutteridge, p.18.

Murphy, 'Report on Conference', p.495.

34 Grant Wardlaw, 'Terrorism: State involvement adds new dimension', Pacific Defence Reporter, Annual Reference Edition (December 1984/January 1985), p.59. 
involved in such incidents and can be linked to attacks on Americans and Israelis in Lebanon, as well as terrorist bombings in Kuwait. Although its support has diminished since 1980, Iraq has consistently sponsored 'Black June', a Palestinian group formed in 1976 and responsible for a number of attacks on Israeli and Arab diplomats in Western Eunope. Perhaps one of the most spectacular examples of state-sponsored terrorism of this kind occurred in Rangoon in October 1983 when members of a DPRK Army team were responsible for a bomb attack on the party of the visiting South Korean President. 35

The frequency of state-sponsored terrorist attacks seems to be growing rapidly. In 1982 the us State Department cliaimed that it had evidence of 129 attacks conducted directly by national governments, 80 per cent of which had taken place in 1980 and 1981. ${ }^{36}$. These accounted for some 25 per cent of all international terrorist attacks for the period. 37 Two years later, the US secretary of state identified over 70 attacks in 1983 alone in which significant state support or participation was felt to have occurred. 38 Such attacks resulted in a large number of casualties. obviously, these figures too must be used with caution. Accurate information on such incidents is difficult to obtain and the figures are most likely distorted by the large number of attacks that Iran and Iraq have been making on each other's diplomats as part of the current war between them. Yet the US statistics are probably correct in reflecting a greater willingness on the part of terrorist groups to

35 See The Bomb Attack at the Martyrs' Mausoleum in Rangoon: Report on the findings by the Enquiry Committee and the measures taken by the Burmese Government (Rangoon, 1984). 36 'International Terrorism', Gist (September 1984), pp.1-2.

37 Paul Wilkinson, 'state-sponsored international terrorism: the problem of response', The World Today (July 1984), p.292. 38 G.P. Shultz, 'Terrorism: The Problem and the Challenges', Statement by the Secretary of State before the US House of Representatives Committee on Foreign Affairs, Washington, 13 June 1984, Current Policy 586 (13 June 1984), p.2. See also Patterns of International Terrorism: 1981, p.4. 
serve state interests and a growing tendency on the part of some states to use terrorism to pursue their foreign policy goals. These trends are important for a number of reasons, one of which is the impact such practices are making on the conduct of diplomacy.

The 1961 Vienna Convention on Diplomatic Relations (Article 4l) specifically enjoins the representatives of sending states to respect the laws and regulations of the receiving state and not to interfere in the internal affairs of that state. The same Article reads in part:

The premises of the mission must not be used in any manner incompatible with the functions of the mission as laid down in the present Convention or by other rules of general international law or by any special agreements in force between the sending State and the receiving State. 39

Yet there have always been cases where the provisions of this Article have been ignored. Diplomats have often strayed close to the edges of propriety ${ }^{40}$ and diplomatic missions have long been used to shelter intelligence agents. This has entailed support for covert operations, including some against the host government. Such operations have ranged from contact with opposition groups and simple intelligence gathering to kidnappings, assassinations and

\section{See Appendix E.}

40 Thayer cites the case of Franz von Papen, the German Military Attache in Washington during the First World War, who was declared persona non grata for being implicated in plots to destroy US ammunition dumps. As early as 1584 the Spanish Ambassador in London was expelled for plotting against Queen Elizabeth I. Thayer, pp.211-212. As Martin Wight has observed, 'Diplomacy and espionage were always distinct in principle. But they have enough in common to be long confused with each other'. Sometimes this confusion has extended to diplomats themselves. Wight, p.116. 
plots against the receiving government. ${ }^{41}$ There appears no precedent, however, to the current widespread use of diplomatic facilities by some states for the purpose of conducting terrorist operations abroad against expatriates and foreign governments. Over the past fifteen years diplomatic bags have been extensively used to smuggle arms and ammunition, and diplomatic premises have often become centres for the storage and distribution of terrorist literature and materials. ${ }^{42}$ Diplomatic communications have been used to coordinate operations between terrorists and their state sponsors and diplomatic credentials have been provided both for state assassins and 'free lance' terrorists.

In addition to this use of diplomatic facilities, diplomats themselves, or at least officials given that title, have been responsible for liaison with terrorist groups, providing them with arms, intelligence about their targets, accommodation and guidance. Calls in April 1982 for a 'purge of the embassies' in Paris followed the discovery that the diplomats of a number of states were implicated in a series of terrorist incidents in France and on numerous other occasions 'diplomats' have been declared persona non

41 A celebrated early example of this was the abduction of Chinese nationalist leader Sun Yat-sen by the Manchu Secret Service in London in 1896. Sun was imprisoned in the Chinese Legation for 12 days before pressure from the Foreign office secured his release. Richard Deacon, AHistory of the Chinese Secret Service (Muller, London, 1974), pp.139-158. In 1966 the Chinese Embassy in the Hague was accused of a similar operation. The ROK and DPRK have often accused each other of abducting one another's nationals in this way.

42

For example, the Palestinian terrorists responsible for the abduction and deaths of the Israeli athletes in Munich in 1972 received their arms from Libyan diplomats who had used diplomatic privilege to smuggle them into Germany. The Canberra Times of 12 February 1973 reported that a cache of arms found hidden in the Iraqi Embassy in Islamabad by the Pakistan government consisted of some 300 automatic weapons, 60,000 rounds of ammunition and grenades, all sealed in diplomatic bags. According to seymour Hersh, the CIA smuggled weapons into Chile in diplomatic bags before the overthrow of Salvador Allende in 1973. S.M. Hersh, The Price of Power: Kissinger in the Nixon thite House (Summit Books, New York, 1983), p.289. 
grata because of similar behaviour in other states. 43 once again, the assassination attempt against ROK President chun Doo Hwan in October 1983 provides a recent example of this development, with the discovery by Burmese authorities that the DPRK 'hit team' receivea' close assistance from members of the North Korean Embassy in Rangoon. 44 while the murder of an English policewoman by a member of the wibyan Peoples' Bureau in London in April 1984 was the immediate cause, it was this continued use of diplomatic facilities for terrorist operations that prompted the seven major economic powers meeting in the UK last year to state that they:

viewed with serious concern the increasing involvement of States and Governments in acts of terrorism including the abuse of diplomatic immunity. 45

Not only have the diplomats of some states been party to state-sponsored terrorism, but they have also been among its victims. A high proportion of terrorist attacks instigated by states have been directed against the diplomats and diplomatic facilities of other states. 46 According to the US State Department, Syria and Iran were directly involved in the bomb attacks against the American Embassies

43 Edward Moxon-Browne, Terrorism in France, Conflict studies 144 (Institute for the Study of Conflict, London, 1983), p.3. Over the past fifteen years, Soviet 'diplomats' have been expelled from Mexico, Bolivia and Colombia; Cubans, Syrians and Iranians from France, Libyans from the UK, US and Italy, and DPRK diplomats from Burma and Sri Lanka, all for their involvement in terrorist activities.

44

The Bomb Attack on the Martyrs' Mausoleum, pp.19-20.

45

Quoted in Frank Brenchley, Diplomatic Immunities and Statesponsored Terrorism, Conflict Studies 164 (Institute for the Study of Conflict, London, 1984), p.2.

46 An early example of this was seen in 1960 when the US state Department claimed that Fidel Castro had assigned agents to assassinate the US Ambassador to Mexico, who had apparently suggested that Mexico's sugar quota to the United States be increased (presumably at Cuba's expense). Mexican police were assigned to protect the Ambassador for over a year. Wilson, p.60. 
in Beirut and Kuwait in $1983^{47}$ and were most probably responsible for the attack on the US Embassy Annexe in Beirut last year. The diplomatic services of both Iran and Iraq have become prime targets for terrorist attack since the war began between those two states in 1980. The Iranian-supported Islamic Jihad openly threatened US, UK and French diplomatic missions after those countries agreed to participate in the multinational force in Beirut in 1983. Libya has openly announced its intention of attacking US diplomatic personnel and facilities and since the Camp David Accords has joined with other 'confrontation states' in sponsoring terrorist attacks against Egyptian missions. State aid to groups like the Armenian Secret Army for the Liberation of Armenia (ASALA) and the HRB directly increases the risks to all Turkish and Yugoslav diplomats and their families. Indeed, it could be argued that as diplomats and their facilities are now viewed as 'legitimate' targets by most terrorist groups then any supnort given to them, whether it be direct or indirect, contributes to the dangers faced by all members of the diplomatic profession. Similarly, any abuse of the diplomatic system by states assisting terrorists raises doubts in peoples' minds about the legitimacy of all diplomatic activity and helps erode the fragile consensus on which the principle of inviolability is based.

States appear to support terrorist operations for a number of reasons. Ideological considerations play a significant role and often involvement includes the export of enforcement terror found in the sponsoring state. Attacks might be prompted by simple vengeance, as in the cases of the Letelier assassination in Washington in 1976, or the assassination of former General Oveissi in Paris last year, 48

47 Sayre, p.1.

48 Former Chilean Ambassador and Defence Minister Orlando Letelier was killed in Washington by agents of DINA, the secret police force of the Pinochet Government. Former Iranian General Gholam Ali Oveissi (the so-called 'Butcher of Tehran') was assassinated by Iranian agents in Paris in 1984 . 
or might be simply to silence critics of the regime. Other cases, like those sponsored by Iran, seem to be inspired by a mixture of political and religious motives. It is possible too that support for terrorist groups is felt by some of the smaller and weaker states to give them an influence in world affairs that would otherwise be denied them. Whatever the reason, the sponsorship of international terrorism represents a rejection of conventional diplomacy and to a degree at least a preference for coercion over peaceful negotiation. However slight, this is a movement along the political continuum towards open conflict. Indeed, such is the scope of state-sponsored terrorism and so significant are the differences between it and earlier social and political struggles by terrorist groups that some observers have come to see the current phenomenon, for all practical purposes, as a form of 'surrogate war', the latest manifestation of the 'camouflaged wars' predicted by Sir Basil Liddell-Hart and Andre Beaufre in the 1950s and 1960s. 49

In a thesis first proposed in 1975 and elaborated further in 1983,50 Brian Jenkins of the Rand Corporation has argued that because of the nuclear stalemate between the two superpowers opposing states have been obliged to choose between conventional wars and protracted unconventional wars. As a general rule, however, the former are becoming increasingly impractical. They are too costly, too destructive and too unpopular in domestic and world opinion. Short 'lightning' wars like the 1967 Six Day War or the

\footnotetext{
49 Basil Liddell-Hart, Strategy: The Indirect Approach (Faber, London, 1967), p.373 et. seq. and Andre Beaufre, Introduction to strategy - with particular reference to problems of defence, politics, economics and diplomacy in the nuclear age (Faber, London, 1965), pp.107 et.seq.

50 High Technology Terrorism and Surrogate War: The Impact of New Technology on Low-Level Violence (1975) and New Modes of Conflict (1983).
} 
Turkish invasion of Cyprus in 1974 are still an option but are often inconclusive. Protracted wars have other drawbacks, as demonstrated by the Vietnam War. An alternative mode of warfare, Jenkins has argued, is a campaign of low level terrorist violence. By taking advantage of developments in modern society, in particular arms technology and the legal ambiguities of international terrorist operations, states can wear down the capacities and resolve of their enemies through a series of clandestine attacks. These can be made on targets within the state or, as in the case of attacks on diplomats and diplomatic facilities, against the assets of a state beyond its national borders. Jenkins apparently believes not only that such a conflict is likely but that it would jeopardise the present system of international order based on a community of sovereign states, even the concept of nationhood. 'War will cease to be finite, the distinction between peace and war will dissolve' leaving states in an environment not unlike the anarchy of Renaissance Italy. 51

While this argument is persuasive, it contains a number of serious flaws. It is true that the current nuclear balance which constrains the major powers from total war has produced a kind of stability in which lower level conflicts can flourish, but however costly and unpopular conventional wars are still seen as a real option, as evidenced by the Iran-Iraq war. 52 Nor is it likely that protracted guerrilla campaigns will ever disappear for, quite apart from indigenous considerations, they continue to serve the wider strategic purposes of the superpowers themselves, as seen in Afghanistan and Central America. 'International terrorist attack is a different mode of war, not an alternative to war as such'.53

51 High Technology Terrorism and Surrogate War, p.3 and pp.24-25, and New Modes of Conflict, p.16.

52 This point is emphasised in 'New weapons don't always win wars', The Weekend Australian Magazine 8-9 December 1984, p.8. 53 wilkinson, Terrorism and the Liberal State, p.179. 
There is a trend towards the development of terrorist violence as part of the world's strategic composition but not all such campaigns can be included within the pattern outlined by Brian Jenkins. As Grant Wardlaw pointed out last year, for example:

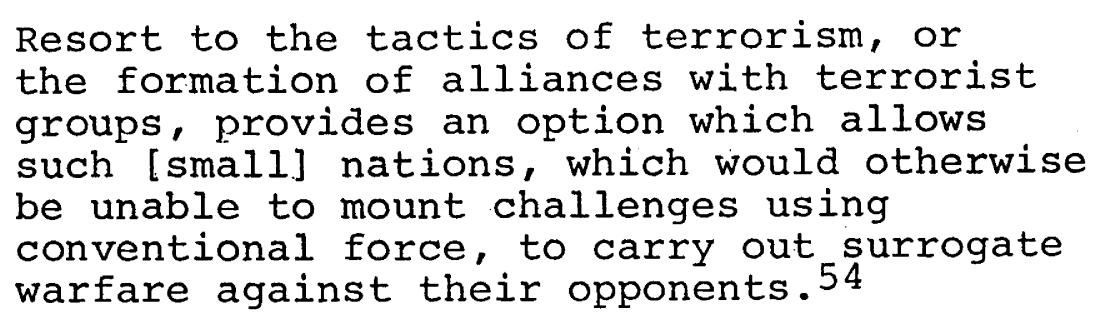

In such cases, terrorism is seen simply as a cheap weapons system and while it may be used in conjunction with wider conflicts it should not automatically be viewed as part of one. Jenkins does not distinguish between terrorist activities in this way, however, nor does he seem to allow for terrorist acts unrelated to significant political contests. His vision of surrogate warfare between states is really only applicable to conflicts between major powers and even then fails to accord sufficient weight to the readiness of the international community to take steps against universally disruptive political violence.

Despite its shortcomings, or perhaps as a result of them, this thesis seems to have been readily adopted by the US government. As early as 1975 the Special Assistant to the Secretary of State and state Department Coordinator for Combatting Terrorism testified to a US Senate Subcommittee in terms very similar to those used by Jenkins in his first paper on this subject. 55 The idea of a global power shunning outright war but still pursuing its strategic objectives

54 Grant Wardlaw, 'Strategic Aspects of Political Terrorism', Address to the Joint Services Staff College, Canberra, 29 February 1984 (unpublished paper, p.20).

55 'Terrorist Activity: International Terrorism', Hearings. 
through terrorist surrogates has also found a receptive audience among senior members of the Reagan Administration, which has cited with approval claire sterling's claims that the Soviet Union is operating a 'terror network' through its Eastern European satellites, the PLO and Cuba. 56 Congress too has given credence to suggestions that there is 'a large Communist terrorist force, a Communist army which ... is not yet fully deployed'. 57 This 'low intensity warfare' by the Eastern bloc is seen as part of a concerted effort to expand its influence around the world and is purportedly aimed at everything from the West's strategic interests in Western Europe, the Middle East and the Caribbean to weakening liberal democracy and undermining world stability. ${ }^{58}$

As Grant Wardlaw and others have pointed out, 'the evidence of Soviet support for destabilising influences in the Western-aligned world is overwhelming, but it indicates a capacity for opportunistic exploitation of situations rather than their specific creation and direction'. ${ }^{59}$ To view the Soviet Union as the 'puppet master' of world terrorism is to ignore the many, often subtle differences between terrorist groups, their aims and ideologies. In many countries the radical right poses as great a threat as the revolutionary left and the political commitment of many terrorist groups is shallow and changeable. Despite rhetorical flourishes and short-term alliances, terrorists (like states) have tended to remain stubbornly independent and have refused to submerge their differences in 'a sea of

\section{6 sterling, passim.}

57 'Historical Antecedents of Soviet Terrorism', Hearings before the Subcommittee on Security and Terrorism of the Committee on the Judiciary, US Senate, 97 th Congress, First Session, 11-12 June 1981 .

58 see in particular Shultz, 'Terrorism: The Challenge to the Democracies', pp.2-3 and Sayre, p.2.

59 Wardlaw, Political Terrorism, p.56. 
world revolution'. 60 obviously, any weakening in political stability and social cohesion in the west can affect the overall 'correlation of forces' between the two major blocs, 61 but the simplistic and misleading picture of world terrorism painted by sterling and others serves only to reinforce the prejudices of the Reagan Administration, which has already displayed a tendency to view complex global problems in simple East-West terms. Such an approach also ignores America's own involvement in terrorism of different kinds.

Over the years the US too has 'hired gunmen, mobs and private armies with which to protect her foreign policy interests'.62 American efforts have included offensive operations but in recent years have been largely reactive. They have included in particular support for regimes which have relied on enforcement terror to remain in power and have been justified publicly by a double standard that has made anti-communist terror acceptable while terror used by the US's opponents has been deemed worthy of universal condemnation. This approach is exemplified best by the speech made in 1979 by the US's Permanent Representative to the United Nations on 'Dictatorship and Double Standards', in which a distinction was made between 'totalitarian'

60 J.B. Bell, 'Contemporary Revolutionary Organisations' in R.O. Keohane and J.S. Nye (Eds), Transnational Relations and World Politics (Harvard University Press, Cambridge, 1981), p.167.

61 W.S. Thompson, 'Political Violence and the "Correlation of Forces"', Orbis 19:4 (Winter 1976), pp.1270-1287.

62 Thompson, p.1282. There have been a number of recent suggestions of US complicity in assassination plots and similar terrorist operations. Seymour Hersh's study of former Secretary of State Henry Kissinger, for example, suggests that the Us was responsible for, or at least implicated in, the assassinations or attempted assassinations of Fidel Castro, Salvador Allende, Patrice Lumumba, Rafael Trujillo and Nguyen Van Thieu. Hersh, pp.274-277. 
regimes such as the Soviet Union and 'authoritarian' regimes such as those military dictatorships supported by the US. This same distinction was drawn when Mrs Kirkpatrick spoke about terrorism to the Jonathan Institute in Washington in June 1984. On that occasion her argument was essentially the same, that motives were crucial and that while terror used in defence of society was acceptable, terror used to destroy it was not. 63 The difficulty with this argument, however, lies in the fact that such distinctions rely on subjective moral judgements as much as those made by the US's opponents when describing terrorists as 'freedom fighters'. Inevitably, ideological factors enter into consideration of the problem and diplomatic solutions become more elusive.

Terror has always been seen as an option by states whenever their national interests seem to have required it, so much so that in some respects terror has almost become 'acceptable'. Such is the history of repressive state policies, support for dictatorships, clandestine interventions and covert operations against individuals that, as Michael Stohl has shown, 'policies of terrorism in the international system have grown to the status of legitimate (i.e. considered to be legitimate) behaviour'.64 Nowhere is this demonstrated better than in the diplomatic field. Raymond Aron made the point over twenty years ago that the distinction between diplomacy and strategy was purely relative. 65 Drawing on Thomas Schelling's analysis of the nuclear 'balance of terror', Stohl has gone further and suggested that terrorism

\footnotetext{
63 This speech was expanded and printed as J.J. Kirkpatrick, 'Defining Terrorism', Catholicism in Crisis (September 1984), pp. $41-44$.

64 Stohl, 'National Interests', p.40.

65 Aron states that 'The distinction between diplomacy and strategy is an entirely relative one. These two terms are complementary aspects of the single art of politics - the art of conducting relations with other states so as to further the "national interest"'. Raymond Aron, Peace and War: A Theory of International Relations (Praeger, New York, 1970), p. 24 .
} 
has now become part of the 'coercive diplomacy' which states have always used to produce changes in their opponents' political positions through symbolic violence and the fear that non-compliance will bring punishment 'terrible beyond endurance'.66 Thus a campaign of international terrorism can become a tool of states, an extension of foreign policy by other means, placed on a scale between absolute peace and outright war. In suoh a situation, diplomacy can be regarded as being more or less effective depending on the ability of states to manipulate the threat of terrorist violence as a means of exerting pressure and winning desired policy changes. As Michael Stohl has written, 'the threat is quite explicit, even if it is non-verbal'.67 If seen in such a light, such 'tacit negotiation' 68 challenges the assumptions in the traditional definition of diplomacy as 'the conduct of business between states by peaceful means ${ }^{169}$ and gives greater weight to the assumptions of the Realist school whose 'diplomacy of violence' is discussed by schelling and Stohl. To the Realists, diplomacy has never been a matter of 'pure persuasion', but has always contained an element of symbolic or clandestine violence. 'The power to hurt is bargaining power. To exploit it is diplomacy - vicious diplomacy, but diplomacy'.70 Long understood and accepted in terms of conventional power ('gunboat diplomacy') and nuclear exchanges, this relationship between terrorism and diplomacy is only now becoming plain.

\footnotetext{
66 schelling, p.15.

67 Stohl, 'National Interests', pp.41-42.

68 The term is Dean Acheson's, quoted in Eayrs, pp.71-72.

69 satow, p.1.

70 Schelling, p.2 and Aron, p.61. Horatio Nelson is reputed to have claimed that a man-o'-war was 'the best negotiator in Europe'.
} 
Such a development has caused considerable concern, not only because of the threat to lives and property, but also because of fears that the international system itself cannot survive such a challenge. The United States in particular has warned of the threat to the institution of diplomacy, to world stability and even to civilisation itself. 71 with its perception of international terrorism as being essentially soviet-inspired, the US has blamed this impending catastrophe on the USSR, but once again the situation is a great deal more complex than that portrayed by members of the Reagan Administration. Whereas in the past the international system could be controlled to a significant degree by the superpowers and their allies, this is no longer the case. The system is much more fluid, with a greater number of states and non-state actors, many of which act independently of the major blocs. Some have chosen to indulge in activities that are inimical to the interests of the major powers regardless of their political persuasion. Terrorist activities that have been 'legitimate' in the past are no longer taking place in a system controlled by these powers and are thus considered more threatening. New forms of terrorist attack, such as those against diplomats and diplomatic facilities, challenge norms of international behaviour that affect all states.

The Soviet Union has been more successful than the United states in manipulating these new forces but is itself also threatened by them. One does not have to be an apologist for the Soviet Union, as Cline and Alexander have suggested, to feel that 'the dynamics of modern terrorism is so uncontrollable as to make soviet leaders ambivalent about

\footnotetext{
71 see in particular Shultz, 'Terrorism: The Challenge to the Democracies' and K.W. Dam, 'Terrorism in the Middle East', Address by Kenneth W. Dam, Acting Secretary of State, to the leaders of the National United Jewish Appeal, Washington, 1 October 1984, Current Policy 618 (1 October 1984), pp.1-2.
} 
this form of warfare'. 72 The threat from international terrorism is also faced by the Eastern bloc which now has global interests and vulnerabilities of its own. The latter include diplomats and diplomatic facilities and far from attempting to destroy the institution of diplomacy, as claimed by the US, the Soviet Union has shown a concern to join with other states in protecting and strengthening it.

72 Cline and Alexander, p.5. 
Chapter IV

THE RESPONSE

Anti-Terrorist Measures

The state of peace among men who live together is not a natural state; for the natural state is one of war, ie if not a state of open hostilities, still a continuous threat of such. The state of peace must be established.

Immanuel Kant

Perpetual Peace: A

Philosophical Proposal

(1795)

Before the 1960s, diplomats could usually rely on the host country's laws, international custom and other traditional restraints to protect them from violence. The increasing frequency of attacks on diplomats and diplomatic facilities by terrorists after that time, however, made it necessary for both sending and receiving states to reassess the measures normally taken for the protection of the personnel and property for which they were responsible. Matters which had formerly been examined only occasionally and on a piecemeal basis required much deeper and broader consideration. ${ }^{1}$ As a consequence, a number of complex political and legal issues were raised over the measures required and the states responsible for their implementation. In addition, there were differences in perceptions and capabilities between the older, established and often wealthier states and the newly-constituted non-European states with fewer resources and a shorter history of

1 Baumann, pp.43-53 and p.110. 
participation in the formal diplomatic process. The fragility of diplomatic relations was exposed and the tactical advantages held by the terrorists made clear. Above all, the international scope of terrorist activities emphasised the interdependence of modern states and the need for cooperation if the terrorist threat to diplomats and diplomatic facilities was to be countered effectively.

As might have been expected, the first efforts to protect diplomats and their facilities were made by the sending and receiving states themselves... Arguably, they have included the most successful and the most controversial measures. Over the past twenty years most states have taken steps to upgrade the physical security of their missions abroad, the level varying with the threat perceived and the resources available. Perimeter defences have been strengthened and protective screens added to approach roads and buildings. Surveillance and alarm systems have been installed and various other measures taken both to prevent unauthorised access to diplomatic facilities and to protect those working inside them. Since the 1979 Iranian hostage crisis additional precautions have been taken by many states to guard against attacks by violent crowds. 2 . More recently, there have been reports that states are giving greater consideration to the relocation and even the redesign of diplomatic facilities in order to make them more secure. 3 Many missions are now guarded by armed police or military personnel from the sending state and it is likely that the

2 F.H. Perez, 'The Impact of International Terrorism', Address by the Acting Director, Office for Combatting Terrorism, US State Department, Byliner 5 (January 1982), p. 4 .

3 Newsweek reported in December 1984 that the National Research Council of the US National Academy of Sciences was trying to develop a new kind of architecture for diplomatic buildings that was safe yet blast resistant, visually appealing yet secure. 'Embassies Under Siege', Newsweek, p.146. See also 'Terrorism vs. glamour in life of diplomat', US A Today, 10 October 1984, p.i. 
attachment of security officers to such facilities will become more common. 4

A number of steps have also been taken to protect diplomatic staff and their families outside the security of mission buildings or compounds. The senior diplomats of many states now travel in specially armoured vehicles and are often accompanied by personal bodyguards. In 1970, after the rash of kidnappings and murders of diplomatic personnel in Latin America, the US State Department sent all its embassies and consulates in the region a directive calling for a drastic reduction in travel and greater secrecy in the planning of any essential trip. Diplomatic staff were urged to travel to and from work either in convoys or in inconspicuous vehicles. They were also advised to vary their daily routines in order to reduce the risk of seizure. 5 Other measures implemented by the US, and by many other states threatened by terrorist action, include the introduction of staggered working hours and the preparation of contingency plans to be followed in the event of an attack. Brief training courses have been given to diplomats and their families on how to respond to a terrorist threat and secure 'safe havens' have been built into many diplomats' homes. Clifton Wilson cites a State Department report that American diplomats in Southeast Asia in the 1950s were instructed to carry firearms but this provocative and risky practice does not appear to be widespread now. 6 In some high risk areas the size of diplomatic staffing establishments (including officers' families). have been reduced to provide terrorists with fewer potential targets and from time to time there have been reports of missions being withdrawn because the receiving government could not provide adequate protection

\footnotetext{
4 'Diplomats Forced to Adapt to New Era of Terrorism', p.21. 5 Stechel, p.213. See also 'The New Terror Network', Newsweek, p.111.

6 Wilson, p.61.
} 
against attack. These were the grounds, for example, on which the FRG Embassy in Guatemala was closed after count von Spreti's kidnapping and murder in 1970 and similar reasons have been put forward to account for the departure of a number of missions from El Salvador and Lebanon in recent years. 7

The closure of a mission, however, is rare outside of a complete breakdown in civil order and even then might not be an option for a large power or one with vital interests at stake. ${ }^{8}$ In most cases sufficient protection can be provided by the receiving state to warrant keeping missions open. Since the terrorist threat to diplomats reached serious proportions in the late 1960s and early 1970s a number of states have amended their legislation to permit them greater freedom in trying to prevent a terrorist incident and in responding should one occur. 9 Improved immigration procedures have reduced the ease with which international terrorists can travel and tighter customs controls have made it more difficult for them to transport their arms and explosives. Postal services have been alerted to watch for bombs in the mail and devices for their detection have been installed in many post offices. In a number of countries specialised government agencies have been created to coordinate any action required against terrorists. 10 Such agencies usually have access to special skills, such as intelligence analysts, communications officers, trained

7 Baumann, pp.98-101 and Palliser, in Bull and Watson, p.353.

8 For example in 1984, during an upsurge of fighting between militant factions in Beirut, Australia withdrew its diplomatic mission. The United States, although it reduced the numbers of Embassy staff members and their families in the country, kept its mission open. US staff numbers were further reduced in March 1985 but there was obviously no question of the US mission closing, regardless of the danger, given its interests in the region and the need to maintain a presence for symbolic reasons.

9 Murphy, in Evans and Murphy, pp.281-285, and Murphy, in Bassiouni, p.306.

10 See for example Trent, pp.4-7 and the Postscript to this thesis. 
negotiators and tactical response experts. In addition, many states have developed specialised police and military capabilities for use in an anti-terrorist role.

More than 15 states are known to have developed specially trained units capable of mounting armed assaults on terroristheld premises ${ }^{11}$ and it can be assumed that most, if not all, have prepared for missions to rescue diplomats held hostage in their own facilities. 12 The assault on the Iranian Embassy in London in May 1980 by a team from Britain's Special Air Service Regiment was a spectacular example of the kind of response that is available to governments with such units at their disposal. 13 The success of this operation, however, and similar assaults against hijacked aircraft in Entebbe, Mogadishu and Bangkok, must be weighed against the equally spectacular failure of the US mission in April 1980 to rescue the American diplomats held hostage in Tehran and the debacle at Lanarca Airport in 1978. The risks involved in such operations are extremely high. As the assault on the Iranian Embassy in London and the operation in Iran demonstrated in their own ways, even the best laid plans can go wrong, jeopardising not only the lives

11 While in some respects an example of the more journalistic recent studies of the terrorist phenomenon, Christopher Dobson and Ronald Payne's study Terror! The hest Fights Back (Macmillan, London, 1982) usefully surveys these counterterrorist forces. See also R.H. Shultz, 'The State of the Operational Art: A Critical Review of Anti-Terrorist Programs' in Shultz and sloan, p.34.

12

This is apparent, for example, from the'Sunday Times' Insight Team, Siege! Princes Gate, London, Apriz 30-May 51980 (Hamlyn, London, 1980) and 'Inside the SAS: risking all for the sandy beret'. The Weekend Australian Magazine 3-4 November 1984, pp.1-2. In his account of the development of the US's own anti-terrorist unit, Colonel Charles Beckwith described how members of Delta Force travelled around the world, carrying diplomatic bags and inspecting US embassies. C.A. Beckwith and D. Knox, Delta Force (Arms and Armour Press, London, 1984), pp. 170-171.

13 siege!, passim. 
of the attacking counter-terrorist force but also those of the hostages. In addition, there can be no guarantee that circumstances will permit such units to be used, particularly if the operation needs to take place in another country. 14 Practical and international legal constraints are particularly high where diplomats or diplomatic facilities are involved. More importantly, the stakes involved in such operations in terms of national prestige and international influence are huge and it is unlikely that units of this kind will ever be used except in the last resort, and with very great reluctance.

Another major problem arises over the resources required to protect diplomats and diplomatic facilities from terrorist attack. While vague about the actual level of protection required, the Vienna Conventions on Diplomatic and Consular Relations both clearly place the primary responsibility for the safety of diplomats and their facilities on the receiving states. Yet the rapid expansion in the size and number of missions since 1945 has placed a considerable burden on such states, particularly in areas of high risk such as Central and North America. At the height of the kidnapping problem in the early 1970s, for example, more than ten per cent of the entire Guatemalan armed forces was assigned to act as bodyguards for foreign diplomatic personnel at an annual cost of US\$1-2 million for each mission. 15 At the other end of the scale, the United states is currently responsible for over 16,000 accredited diplomatic personnel, their families and some 1,500 consuls and honorary consuls. Most are based in New York and Washington but many live in

\footnotetext{
14 The limitations of such units are brought out by Brian Jenkins in The Lessons of Beirut: Testimony Before the Long Commission, Rand Note N-2114-RC (Rand Corporation, Santa Monica, February 1984). See also Crenshaw, pp.17-23 and C.C. Aston, Political Hostage Taking in Western Europe, Conflict Studies 157 (Institute for the study of Conflict, London, 1984), pp.10-11.

15 Jenkins, Diplomats on the Front Line, p.7 and Murphy, 'Report on Conference', p.483.
} 
cities scattered across the country. ${ }^{16}$ Even with an allocation from Congress of US\$9.5 million in 1985 the US government agencies responsible cannot provide adequate protection for them all. 17 The extent of this problem is such that some of the smaller states have suggested that a distinction be made in international law between those states able to offer adequate security for diplomatic missions and those which cannot. 18 Similar burdens, however, are also carried by some sending states, particularly those most often subject to terrorist attack. The US, for example, as the most favoured target, currently spends around 15 per cent of its state Department budget on security for its missions abroad but according to Paul Wilkinson even this annual expenditure of US\$200 million is not enough to provide adequate protection for them all, the cost of which would be prohibitive. 19

In the final analysis, it must be accepted that while security measures may help deter terrorists there can never be complete security from an imaginative and determined attack, particularly if the terrorists are prepared to martyr

16 Hearings: State Department FY 1984, and Hearings of the US House of Representatives Appropriation Committee: Budget Explanation: State Department FY 1982 (1982). In 1982 New York had the largest diplomatic community in the world, with slightly fewer than 10,000 accredited diplomatic personnel and some 25,000 dependents. The same year there were some 6,000 diplomats in Washington, with around 13,600 dependents. If the 1,500 consuls and honorary consuls in the country are added, the US government is left with a diplomatic community of approximately 56,000 people for whose protection it is legally responsible.

\section{Hearings: State Department FY 1984.}

18 This problem was in fact foreseen by some of the newer states present at the 1961 Vienna Conference. They were loath to see the extension of diplomatic immunities to non-diplomatic personnel attached to Western embassies and sought to restrict the extension of privileges to professional diplomats. See Boyce, p.198 and p.213.

19 Wilkinson is quoted in 'Violent Tactics', Wall street Journal 2l April 1983, p.23. See also Jenkins, The Lessons of Beirut, p.5. Jenkins states that over 2,000 man-years are devoted annually to the protection of US diplomats abroad. 
themselves in the attempt or if they are supported by the host state. As Brian Jenkins explained to the Long Commission in February 1984, terrorist operations are very hard to predict. Also, there is an inescapable asymmetry between the two sides. 'Terrorists can attack anything, anywhere, anytime. Governments cannot protect everything, everywhere, all the time.' 20 There will always be areas that remain vulnerable to attack. As protection is increased in one area, so the attention of terrorists will turn to others. Brian Jenkins believes, for example, that embassy seizures grew out of the increasing difficulty of seizing aircraft because of tighter security at airports. The increased level of bombings and assassination attempts in recent years appears to be a response in turn to tighter security measures to protect diplomats and their facilities from seizure. 21 Another option for the terrorists is simply to increase the scale and violence of the attack, with a greater likelihood of casualties. The attack on the US Embassy in Beirut, described in 1978 as 'a fortress', 22 was a major psychological victory for the terrorists not only because of its importance as the US's headquarters in Lebanon, and therefore the symbol of the Reagan Administration's Middle Eastern policies, but also because of the elaborate measures taken to protect it. A delicate balance needs to be struck between those measures which will help deter attacks and those which, by the nature of the commitment made and the prestige invested, may invite them.

The greatest problem faced by states in this area, however, lies in the nature of diplomacy itself. For diplomacy must be conducted openly, with ready access to other diplomats,

\footnotetext{
20 Jenkins, The Lessons of Beirut, p.4.

21 Jenkins, Embassies Under $S$ iege, p.20.

22 Murphy, in Evans and Murphy, p.290.
} 
a wide range of officials and members of the local population. To some areas of a diplomatic mission, such as the consular and commercial sections, free access by the public is crucial. Yet such freedom of movement provides opportunities for the terrorists which they have been quick to exploit. To restrict the access of the public to the mission and for diplomats to have fewer contacts with people outside it might add to the security of the mission but would also greatly reduce its effectiveness. It would also have a detrimental effect on the morale of the mission staff and their families. 23 Paradoxically, it is often in precisely those countries where the terrorist threat is highest that diplomacy has the greatest role to play, demanding a larger staff, freer movement and wider contacts outside the mission. Once again, a balance needs to be struck between the interests of security and the requirements of diplomacy, but such a balance will always provide opportunities for terrorists. The best that can be done in such circumstances, perhaps, is to prepare for the inevitable.

As John Murphy has stated, 'the proper strategy and tactics for governments to employ in response to kidnappings and other attacks on diplomats are key elements in any policy designed to enhance diplomatic protection'. 24 Many states have devised contingency plans for use in the event of terrorist attacks on diplomatic targets within their spheres of responsibility, but there is considerable controversy over the approaches adopted. The 'hard line' states, led by the United States and Israel, have held the receiving states primarily responsible for the safety of their diplomatic missions and

\footnotetext{
23 A number of experts have even argued that increased security measures should be taken purely to maintain staff morale and to attract diplomatic officers and their families to high risk posts. See 'Violent Tactics', hall Street Journal, p.23 and D.D. Newson, 'The Diplomat's Task versus Security' in Herz, p.11.

24 Murphy, in Evans and Murphy, p.297.
} 
argued that only by firmly resisting their demands can terrorists be shown that their actions will not pay. Prompted by past experiences, in which accession to terrorist demands seemed to encourage further attacks, they have refused even to negotiate with the terrorists. Diplomacy is seen, at best, as a technique which can help defuse some dangerous situations and which is useful in broad conceptual areas of policy formulation, but which is not particularly relevant to the resolution of specific terrorist incidents. ${ }^{25}$ The British Ambassador to Uruguay may have felt in 1971 that the Tupamaros 'had moved by kidnapping him into "the diplomatic world of negotiations"', 26 but the advocates of a hard line would claim that:

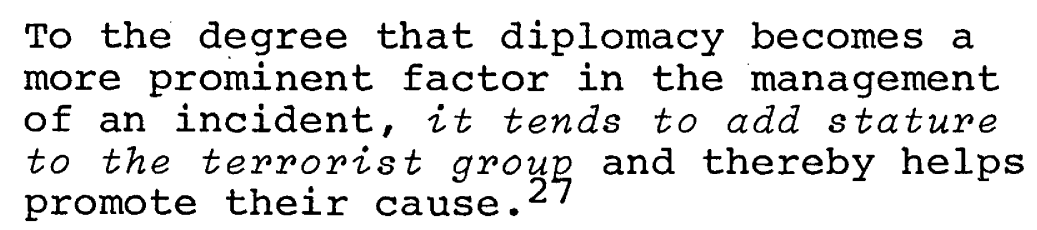

The governments of some hard line states have been prepared to see their own diplomatic officers murdered by terrorists rather than change their approach. 28

The 'soft line' states on the other hand see considerable value in 'diplomatic solutions'. Not only is diplomacy considered useful in the coordination of responses from the various governments and security forces that might be involved, but traditional diplomatic skills have also been used to

\section{Karkashian, in Herz, p.8.}

26 Quoted from a press conference given in September 1971, in Baumann, p.109.

27 Karkashian, in Herz, p.6 (emphasis retained).

28 The members of the Black September Organisation who seized the Saudi Arabian Embassy in Khartoum in 1973 are reputed to have killed their American and Belgian diplomatic hostages after hearing over the radio that President Nixon was resolved to hold to the US's policy never to treat with terrorists. Just as the US was determined to show its resolve, so too were the terrorists who were anxious to counteract any impression of weakness that may have been given by the collapse of the Israeli Embassy seizure in Bangkok three months before. 
explore options with the terrorists themselves, particularly when the lives of hostages have been at stake. The soft liners argue that there is no evidence that a strong stand against negotiations helps significantly to reduce the frequency of terrorist attacks, which are often made for reasons additional to those included in any stated demands. often, the publicity given to an incident is justification enough, something that would be achieved regardless of the policies of the governments involved. ${ }^{29}$ By holding the receiving states solely responsible for the resolution of terrorist incidents the hard line states in effect contribute to the success of the operation by adding to the pressure and embarrassment felt by them. Moreover, by discarding their options before an incident has even occurred, hard line states effectively nullify their own capacities to react when one does. Should such a state eventually feel obliged to negotiate it loses more prestige and international bargaining power than if it had initially taken a more conciliatory approach. 30

Such considerations play an important part in the formulation of state policies. The high symbolic content of any terrorist attack usually means that questions of 'face' or national prestige quickly become of paramount

29 This is the conclusion for example, in Jenkins, Embassies Under $S$ iege, and Jenkins et.al., Numbered Lives, p.32. A study by the Carnegie Endowment for International Peace also found that a primary motive in international hostage incidents was publicity. See Murphy, in Evans and Murphy, p.297 and F.J. Hacker, 'A Case Study of Hostage Negotiation' in Herz, p. 4 .

30 There will also be occasions when the imperatives to negotiate will outweigh even the most rigid state policies against doing so. There is evidence to suggest, for example, that the Israelis were prepared to negotiate with the hijackers of the Air France Airbus at Entebbe in 1976, just as they had been forced to do twice before. Yehuda ofer, Operation Thunder: The Entebbe Raid (Penguin, Harmondsworth, 1976), pp.55-58. See also Katz, p.314. 
concern. The terrorists see themselves as representatives of their cause before the world, while their adversaries are symbols of systems or policies which they oppose. To the states, however, the terrorists represent a public challenge to their ability to manage their own affairs, fulfil their legal responsibilities and protect their citizens. Terrorism tests their resolve and their reputation for action in the pursuit of their own interests. Thus neither side wishes to appear weak or vaccillating, nor to accord the other side a status to which it is not felt entitled. By their actions, each side attempts to establish its own legitimacy and the illegitimacy of its opponent. These symbolic duels are invariably conducted in the full glare of world-wide publicity, making both sides highly sensitive to the effect their actions might have on their public image. As Robert Jervis, Martha Crenshaw and others have noted, such perceptions of strength and resolve are crucial factors in international relations on which depend issues much wider than the resolution of a particular terrorist incident. 31 Thus the stakes are quickly raised and responses by states to international terrorism become part of global politics, with all the added complications and dangers which that brings.

The need for victim states to appear resolute in the face of terrorist provocation and able still to command the initiative in a situation where the terrorists can always choose the time, place and method of attack, has encouraged a number of states to form counter-terrorist units capable of offensive operations. Israel and South Africa, for example, have long carried out reprisal raids for terrorist attacks and since 1972 Israel's Central Institute for Intelligence and Security (Mossad) has sent 'hit teams' throughout Western Europe and the Middle East to assassinate Arab terrorists

31 Robert Jervis, 'Deterrence and Perception', International Security 7:3 (Winter 1982/1983), and Crenshaw, passim. 
believed responsible for attacks on Israeli targets. ${ }^{32}$ Similar operations have been carried out by the Spanish government against Basque ETA terrorists in France and the FRG has reportedly sent small zeilfahndung (target squads) to abduct terrorists living abroad and return them to Germany for trial. 33 The Yugoslav Security Service (UDBA) has apparently sent assassins to locate and kill Croatian terrorists and a number of Latin American governments are thought to have sent agents abroad to kill terrorists who had escaped capture in their own countries. ${ }^{34}$ There is also evidence to suggest that, like their terrorist opponents, the governments of Israel, Spain and Portugal have resorted to car and letter bombs. 35

In April 1984 President Reagan signed a secret National Security Directive (Number 138) authorising the establishment of US counter-terrorist forces 'capable of mounting preemptive or retaliatory raids against terrorist groups'. The formation of officially sanctioned assassination squads was also seriously debated but apparently will not proceed. 36

32 Israel denied its clandestine operations against Arab terrorists until July 1973 when two Israeli agents were captured. The 1982 Israeli invasion of Lebanon was publicly justified by Prime Minister Begin on the grounds that the Iraqi-backed Black June Movement had attacked the Israeli Ambassador in London.

\section{3}

Dobson and Payne, Terror!, p.169, and Dobson and Payne, The Weapons of Terror, pp.140-141. The Basque terrorists belonged to Euskadi ta Askatasuna, or Freedom for the Basque Homeland. France gave ETA terrorists refugee status until January 1979.

\section{4}

Stephen Clissold has claimed that Uprava Draavne Bezbednosti (UDBA), the Yugoslav Security Service, has selectively murdered Yugoslav dissidents abroad, sometimes acting through diplomatic agents. (Clissold, p.14). Argentine and Venezuelan operatives have reportedly carried out operations against terrorists who fled in the 1970s (Jenkins, New Modes of Conflict, p.l3).

35 Dobson and Payne, The Weapons of Terror,p.123 and Alexander, p.xix.

36 Grant Wardlaw, 'Terrorism: How big a threat to peace?' The Age 18 April 1984, p.13. 
The same day that NSD 138 was signed, the Secretary of state gave a major foreign policy address in which he made clear the Reagan Administration's conviction that the only way effectively to combat terrorism was to use force. Mr Shultz criticised the Long Commission for their belief that

'diplomatic alternatives' could be separated from 'military options' and pointed out that 'diplomatic success often rests upon perceptions of military power'. 37 The United States in effect declared war against an unspecified terrorist foe, 'to be fought at an unknown place and time with weapons yet to be chosen'.38 In a speech made in October 1984 the Secretary of state again referred to the need to:
reach a consensus in this country that
our response should go beyond passive
defense to consider means of active
prevention, pre-emption, and
retaliation ... We should take steps
toward carrying out such measures.
There should be no moral confusion
on this issue. 39

The kind of measures being contemplated by the Reagan

Administration as part of its new policy of 'active defence' apparently include the bombing of terrorist bases and training centres, even the forcible removal of regimes sponsoring terrorist groups.

It is difficult to see how military responses of this kind can ever be effective, either in punishing terrorists or in preventing future attacks. While at first sight it might appear that there are a number of ways military force can be used, in fact 'military options in response to terrorism are few'. 40 Israeli reprisals against the Arab states and the

37 B.M. Jenkins, Combatting Terrorism Becomes A War, Rand Paper P-6988 (Rand Corporation, Santa Monica, 1984), p.3.

38 ibid.

39 G.P. Shultz, 'Terrorism and the Modern World', Address by the Secretary of State before the Park Avenue Synagogue, New York, 25 October 1984 (State Department Press Release 242), p.19. 
Palestinians, for example, have not only failed to prevent further attacks but have bred a new generation of terrorists anxious to claim their own retribution. In addition, a strong case can be made that Israeli actions have contributed significantly to the growing popular and diplomatic support now being shown for the Palestinian cause. Policies such as those approved last year by President Reagan are born largely from frustration and the need to preserve public face rather than from any objective assessment of the international terrorist threat and how it might be overcome in the long term. If implemented, these new American policies are instead likely to exacerbate the problem, and leave the US looking weaker and less in command of the situation than before. These policies are also counterproductive in that they, and the measures already taken by some of the.US's allies, narrow the gap between the states and the terrorists and raise a number of serious moral, legal and political questions.

As the scope and seriousness of the international terrorist problem grew, it quickly became apparent that no national government would be able to combat it alone. Steps were soon taken by a number of states to share intelligence on terrorist groups and activities, counter-terrorist techniques and equipment and to cooperate at various levels of law enforcement. Yet effective action against international terrorists was constantly blocked by the ability of terrorists to claim political asylum from sympathetic states, or in other ways to evade prosecution by crossing national boundaries. International law recognised the right of all states to grant territorial asylum, with provisions for the extradition of common criminals but that extradition need not be granted in the case of people accused of political offences. The definition of the latter being left to the states themselves, there has always been: scope for abuses of the system and for states sympathetic to the terrorists' motives to grant them refuge of this kind. Such discretion could not be removed without impinging on the sovereignty of the states in question, but terrorist actions could by international agreement 
be deemed common crimes and thus denied political status. Significantly, the development which first prompted states to consider this action was the growing number of attacks on diplomats and diplomatic facilities in Latin America.

On 2 February 1971 the Organisation of American States (OAS) approved a Convention to Prevent and Punish Acts of Terrorism Taking the Form of Crimes Against Persons and Related Extortion that are of International Significance. ${ }^{41}$ It 'both condemned and classified certain acts of terrorism against foreign officials as international crimes' 42 rather than poltical acts, thus theoretically denying those responsible asylum in any state party to the Convention. These states were bound either to prosecute the perpetrators of such crimes themselves, or extradite them for trial elsewhere. It was, however, a rather loosely worded document which in some respects offered diplomatic personnel less protection than that already promised by the 1961 Vienna Convention. Many Articles were deliberately left imprecise in order to encompass the differing views of the OAS members, who were unable to reach agreement on a number of important issues. The greatest difficulty was encountered in attempts to reconcile the wish of some states (such as Brazil, Argentina and Guatemala) for a strong definition and denunciation of terrorism with the equally strong traditional beliefs of some Latin American states (such as Bolivia and Mexico) in the concept of political asylum. In the event, six states refused to sign the Convention, feeling that it did not go far enough towards combatting terrorism, but with thirteen signatures the Convention was approved.

Only six states eventually became full party to the Convention and Cuba, the country in the region most often accused of being sympathetic towards terrorism, did not even

\footnotetext{
41 Appendix F.

42 Murphy, in Bassiouni, p.297.
} 
participate in the negotiations. The OAS Convention was thus in some respects a rather ineffectual instrument, but it was significant for a number of reasons. It demonstrated above all that, whatever other differences they may have had, all members of the OAS shared a concern for the continuing integrity of the diplomatic process. The Convention was also 'the first international legal instrument to deal directly with the protection of diplomats and ... served as a primary model for the United Nations Convention' 43 which followed three years later. Even before that, it prompted other multilateral fora to consider the question of the safety of diplomats threatened by international terrorism.

In December 1970, shortly after the OAS first began consideration of the issue, the Council of Europe meeting in Strasbourg examined 'The Protection of Members of Diplomatic Missions and Consular Posts'. The Council's Committee of Ministers considered terrorist attacks against diplomats and diplomatic facilities 'grave violations' of 'the most sacred international traditions' and unanimously condemned all attacks on diplomatic and consular personnel, the rëcent spate of kidnappings in particular. $44 \mathrm{~A}$ resolution passed by the Committee recommended member states to survey the security measures then in force for the protection of diplomats and, if necessary, to strengthen them. Members of the Council were also enjoined to examine their national laws to ensure that they adequately provided for the punishment of anyone guilty of such attacks and states were urged to cooperate in the protection of diplomats and their facilities from terrorist action. ${ }^{45}$ In January 1974

43 Murphy, in Evans and Murphy, p. 300 .

44 Quoted in Baumann, p.152.

45 ibid. See also Juliet Lodge, 'The European Community and Terrorism: Establishing the Principle of Extradite or Try' in Lodge, pp.164-194. 
the Committee of Ministers passed another resolution on international terrorism which inter alia identified offences against diplomats as being of particular note. 46 Three years later, the Council of Europe formally agreed to a Convention on the Suppression of Terrorism, which listed attacks on the 'Iife, physical integrity or liberty' of diplomats as one of those crimes for which political asylum could not normally be claimed. 47 Both at the Economic Summit in Venice in 1980 and in London in 1984 attacks on diplomats were strongly condemned by the world's seven leading industrial nations, and measures proposed to help prevent them. ${ }^{4}$ These sentiments were echoed in turn by the council of Europe meeting in Madrid in 1984. With the example before them of the Libyan Peoples Bureau shooting in London in April, the Council approved:

a concerted campaign against terrorism and abuse of diplomatic privileges, and agreed to set up, under the aegis of the Council of Europe, an ad hoc Ministerial body to consider ways of improving the exchange of information on terrorism, including abuses of diplomatic privilege as well as violence against diplomats. 49

In Europe at least there appeared to be agreement about the need for strong united action against the terrorist threat to diplomats and diplomatic facilities. Yet here again appearances belied the reality.

While all of these resolutions, conventions and communiques were made with significant majorities, and most of them

46 Reproduced in R.A. Friedlander (Ed), Terrorism: Documents of International and Local Control, 3 Vols. (Oceania Publications, Dobbs Ferry, 1979), Vol.3, p.563.

47

op.cit., p.565.

48 Wilkinson, 'state-sponsored international terrorism: the problems of response', pp.297-298.

49 Brenchley, p.2. 
unanimously, ${ }^{50}$ they shared a number of shortcomings with the OAS Convention. Because they were all based on consensus they tended to be statements of widely held political principles rather than practical measures for the suppression of terrorism. All were worded sufficiently loosely to permit the states responsible for their implementation considerable latitude in deciding what action should be taken in the event of a terrorist incident in their territories. None were completely binding and none included measures to enforce their application. As with the American states there was still a notable reluctance on the part of European states to abrogate their sovereign right to handle a terrorist attack as they saw fit at the time. In addition, many still placed fear of reprisals and the loss of commercial opportunities above the need to take concerted action against the terrorist threat. The escape clause in Article 13 of the European Convention, for example, has been invoked by five states to date and France, Italy and Belgium have yet to ratify the Convention. 51 French fears that a binding and more effective commitment against international terrorism would cost them economic opportunities in the Middle East resulted in a significant weakening of the communique issued after the London economic summit last year. It was hardly the 'heartening consensus' described by the us secretary of State. 52 Nor has France been alone in these concerns. Britain, the FRG and Japan were all quick to join France in its attempts to fill the economic vacuum left in Iran by the US withdrawal in 1980, despite calls by President Jimmy Carter for trade sanctions against the Khomeini regime while it held

50 Malta and Eire did not become signatories to the European Convention, the former because it was at that time enjoying a short-lived flirtation with Libya, the latter because of a disagreement over the wording of parts of the Convention. See Wilkinson, Terrorism: International Dimensions, p.16.

51 Amos Yoder, 'United Nations Resolutions Against International Terrorism', Terrorism: An International Journal $6: 4$ (1983), p.509.

52 Shultz, 'Terrorism: The Problem and the Challenges', p.2. 
Us diplomats hostage. 53 Well might Amos Yoder ask, 'if countries with the close political relationships of the European Community can not agree on a strong anti-terrorist agreement, how can there be much hope for a worldwide agreement'. 54

Yet despite such obvious manifestations of national self-interest, the record of European (and Japanese) commitments against terrorist attacks on diplomatic targets should not be seen in a purely negative light. The overwhelming support given to the principle that diplomatic institutions deserved special protection is itself significant. Whatever hesitations they may have felt about opposing terrorism itself, the European states (and Japan), like those of the Organisation of American States, agreed that attacks on diplomats and diplomatic facilities were a cause for particular concern. This aspect of the terrorist problem at least attracted a real consensus, not just at a regional level, or among political allies, but at the global level as well.

The growing number of attacks on diplomats and their facilities, and the albeit qualified success of the 1971 OAS Convention led a number of states to press for its universal application. 55 In its 1971 annual Report, the International Law Commission expressed its willingness to prepare draft Articles on the subject. The ILC's proposal came shortly before a request from the secretary-General of the UN, Kurt Waldheim, for the UN General Assembly (UNGA) to

53 Wilkinson, 'After Tehran', p.8.

54 Yoder, 'United Nations Resolutions', p.509.

55 The Netherlands government in particular was anxious to see the OAS Convention (or a similar instrument) extended to worldwide application, following the seizure by South Moluccan extremists of the Indonesian Ambassador's residence in The Hague in April 1970. The murder of the Yugoslav Ambassador in Stockholm by Croatian extremists in April 1971 also helped concentrate the minds of the UN delegates during debates on this matter. 
consider 'measures to prevent international terrorism and other forms of violence which endanger innocent human lives or jeopardise fundamental freedoms'.56 A draft convention prepared by the United States, however, quickly foundered on the perennial problem of the politically ambiguous nature of terrorist activities. By concentrating on the export of agitational terror and ignoring enforcement terror by states the draft provoked the opposition of the Eastern bloc and Third World. Many of these UN members had achieved their independence through revolution and liberation movements of various kinds and were reluctant for various reasons to agree to measures that might, in theory at least, deny others the same option. A number of states, like South Africa, used the rubric of 'anti-terrorism' to justify repressive policies towards their own populations. It was also pointed out that a number of terrorist leaders and sympathisers like Menachem Begin and Regis Debray now enjoyed international respectability, thus demonstrating the transience of political values in the West. 57 Indicative of the problems faced by those seeking a global convention against terrorism was the title of the agenda item, which was amended to read:

\begin{abstract}
Measures to Prevent International Terrorism Which Endangers or Takes Innocent Human Lives or Jeopardises Fundamental Freedoms and Study of the Underlying Causes of Those Forms of Terrorism and Acts of Violence Which Lie in Misery, ... Frustration, Grievance and Despair, and Which Cause Some People to Sacrifice Human Lives, Including Their Own, in an Attempt to Effect Radical Changes.58
\end{abstract}

56 Quoted in A.J. Pierre, 'Coping With International Terrorism', Survival 18:2 (March/April 1976), p.62.

57 Menachem Begin, former leader of the zionist terrorist organisation Irgun Zvei Leumi, became Prime Minister of Israel in 1977 and was later awarded the Nobel Peace Prize. Regis Debray, confidant of Fidel Castro and Ernesto Guevara, and author of Revolution in the Revolution?, later became a Special Advisor and Representative of President Mitterand of France.

58 Quoted in Edward Mickolus, 'Transnational Terrorism', in Stohl, The Politics of Terrorism, p.148. 
Consideration of the matter soon became bogged down in an Ad Hoc Committee. It seems likely that the UN, like the League of Nations before it, will be unable to agree on a broadly based convention on terrorism that will serve any practical purpose. 59

Significantly, no such problems were encountered with regard to the proposed UN Convention on the protection of diplomats. In a resolution passed in December 1971 the UNGA requested the ILC to study the question of the protection of diplomatic personnel, with a view to submitting draft Articles on the subject to the General Assembly. These were prepared and passed to the UNGA in July 1972 with a request for comments. The matter was sent in turn to the Sixth Committee of the UN, where the Canadian delegate, David Miller, expressed the views of many:

Failure to conclude a convention might have adverse effects on the whole fabric of the diplomatic system and on international relations as a whole. If diplomats had to be lodged in fortresses or were exposed to increasing danger, then freedom of opinion and their value to both the receiving and sending state would be so depreciated that in some cases they might be withdrawn. 60

It was an appeal both to principle and to self interest, and one which found considerable sympathy among other states. The following year the UNGA adopted by consensus the Convention on the Protection and Punishment of Crimes against Internationally Protected Persons, Including Diplomatic Agents. 61 Given the sensitive subject matter and the usually deliberate nature of the UN, the Convention was drawn up and

\footnotetext{
59 The League of Nations adopted a Convention on the Prevention and Punishment of Terrorism on 16 November 1937, but it was only ratified by India (in 1941). The Convention never entered into force.

60

Quoted in Hamer, p.772.

61 Appendix G.
} 
opened for signature in a remarkably short time. ${ }^{62}$ It entered into force on 20 February 1977 after being ratified by 22 countries and only four years and three months from its initial inclusion as an agenda item.

The UN Convention, known also as the New York Convention, 'establishes a legal mechanism to ensure compliance with international norms to protect persons who under international law are regarded as being entitled to special protection because of their current activities'.63 As such, it introduced the concept of the 'internationally protected person' into international legal jurisprudence. It also specified the duty of contracting states to establish certain acts against such persons as common crimes, drawing on both the 'extradite or prosecute' formula adopted in the OAS Convention and the provisions of previous legal instruments such as the Vienna Convention on Diplomatic Relations. The UN Convention also contained a number of provisions requiring states party to it to join in cooperative efforts towards the prevention and suppression of attacks on diplomats and punishment of any person guilty of the offence. Paradoxically, the New York Convention parallels the draft convention proposed by the United states to deal with the wider subject of terrorism, but makes no specific reference to terrorism as such, only crimes against internationally protected persons. Thus the Convention resolved the usual problems of definition by avoiding them completely, in the manner of earlier conventions against the hijacking of aircraft, and instead 'focuses on functions of prime concern to all member states regardless of ideology'.64

\footnotetext{
62

H.F. Shamwell, 'Implementing the Convention on the Prevention and Punishment of Crimes Against Internationally Protected Persons, Including Diplomatic Agents', Terrorism: An International Journal 6:4 (1983), p.531.

63

Amos Yoder, 'The Effectiveness of UN Action Against International Terrorism: Conclusions and Comments', Terrorism: An International Journal 6:4 (1983), p.589. 64

Murphy, in Evans and Murphy, p.317.
} 
Like earlier agreements on this subject, however, the New York Convention was not without certain shortccmings. As John Murphy has shown:

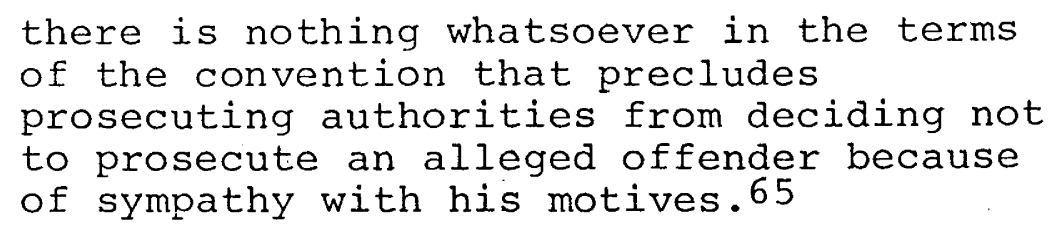

The Convention fails too to deal with such issues as possible sanctions against states party to terrorist attacks, different strategies which might be adopted in cases where ransom is demanded and the question of state liability for injuries received in attacks. In addition, a major ambiguity was introduced into the application of the convention by the UNGA resolution to which it was annexed. Paragraph four of the resolution explicitly provided that nothing in the Convention could 'prejudice the exercise of the legitimate right to selfdetermination and independence ... by peoples struggling against colonialism, alien domination, foreign occupation, racial discrimination and apartheid'.66 observers like L.C. Green have seen this qualification as, in effect, legalising terrorist attacks against diplomats and other protected persons whenever such attacks are made in the name of these causes. 67 Yet perhaps the key weakness of the Convention lies simply in the failure of all states to ratify it. To date only 52 states are party to it, yet without universal acceptance the Convention can only have limited value. Then again, when it is remembered that Iran was already party to it when it 'adopted' the seizure of the Us Embassy in Tehran in 1979, doubts must be thrown even on this assumption. 68

65

op.cit., p.309.

66

Quoted in L.C. Green, 'The Legalisation of Terrorism' in Y. Alexander, D. Carlton and P. Wilkinson (Eds), Terrorism: Theory and Practice (Westview Press, Boulder, 1979), p.186. 67 $i b i d$.

68 The New York Convention was in fact cited in the International Court of Justice's ruling on the seizure of the US hostages in Iran. It might be remembered too that when Idi Amin welcomed the Palestinian hijackers of Air France's Flight 139 to Entebbe Uganda had already ratified the 1970 Hague Convention on the Suppression of Unlawful Seizure of Aircraft. Stevenson, p.168. 
Despite all these shortcomings, the UN Convention on the Protection and Punishment of Crimes Against Internationally Protected Persons Including Diplomatic Agents was a crucial test of the international community's attitude towards the institution of diplomacy. Whatever caveats might indirectly be applied for doctrinal reasons and despite any failures of observance which have been noted since, the Convention underscored the real concern felt on the part of the entire international community over the survival of diplomacy. At no stage was even token dissent registered by a state on this sensitive and controversial issue. 69 Its rapid progress through the councils of the UN showed that 'the perception of officialdom of itself and its prerogatives is shared by both developed and developing countries'70 and demonstrated the willingness of all states to condemn universally disruptive violence of this kind.

All the international conventions and resolutions on this subject which have appeared over the past fifteen years drew on a reservoir of earlier legal instruments and in that sense might be seen as superfluous. There was after all a substantial and growing body of international law which already recognised the special position of diplomatic representatives and which inter alia condemned attacks on them, whether they be perpetrated by states or by independent terrorist groups. Instruments such as the charter of the United Nations (1945), the Universal Declaration of Human Rights (1948), the two International Covenants on Human Rights (1966), the Declaration on Principles of International Law concerning Friendly Relations and Cooperation among states in Accordance with the Charter of the United Nations (1970),

69 This unanimity is all the more remarkable when it is remembered that, while the Universal Declaration of Human Rights did not draw any opposing votes when introduced in December 1948, it prompted eight states to abstain. See Brownlie, p.250.

70 F. Saddy, 'International Terrorism, Human Rights and world Order', Terrorism: An International Journal 5:4 (1982). 
and not least the Vienna Conventions on Diplomatic and Consular Relations (1961 and 1963) could all be cited against terrorist attacks on diplomatic targets. ${ }^{71}$ Yet in themselves these instruments were insufficient to cope with the growing problem. They were ambiguous about the range of persons entitled to special protection and the nature of measures that should be taken to ensure inviolability. They were also unclear about the question of sanctions against people who attacked diplomats and failed completely to address the problem inherent in cases where the attack is made in one country by terrorists who seek sanctuary in another. Finally, traditional international legal measures lacked established procedures for international cooperation in preventing and punishing violations of diplomatic immunity. 72

Not all these weaknesses have yet been rectified, but that there has been such an effort to do so is indicative of the strength of commitment by all states to the continued survival of the diplomatic institution. Whether from positions of principle or, as seems more likely, purely self interest, it is seen still as important and worth preserving. This was demonstrated yet again in 1980, when the UNGA adopted by consensus a resolution which deplored all violations of international law governing diplomatic and consular relations, strongly condemned acts of violence against diplomats and diplomatic facilities and strongly urged all states:

to take all necessary measures with a
view to ensuring, in conformity with
their international obligations, the
protection, security and safety of
diplomatic and consular missions and

71 All these documents can be found in Brownlie's excellent collection of Basic Documents in International Law. It might be noted that some of these documents contain the same ambiguities as the New York Convention itself. The UN Declaration of Principles of International Law, for example, decries support for terrorism but enjoins states to support movements against racism and other forms of oppression. See Wilkinson, Terrorism and the Liberal State, p.232.

72 This paragraph is drawn largely from Murphy, in Evans and Murphy, pp.295-296. 


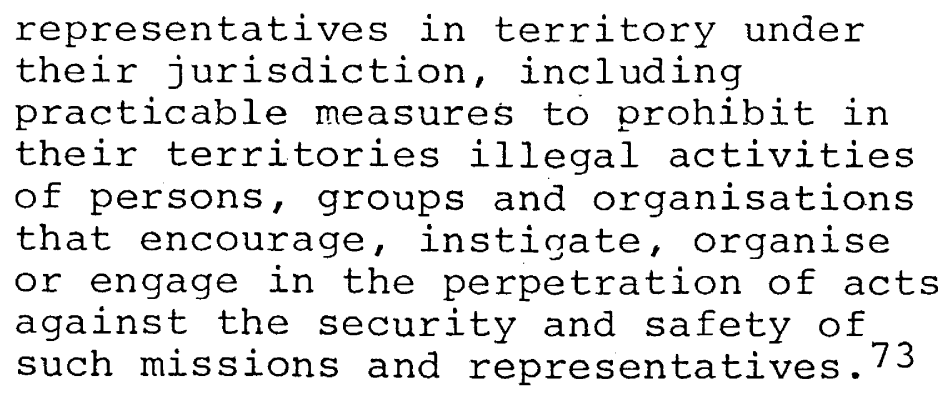

This resolution was reaffirmed by the entire membership of the UNGA in 1981. Diplomats and diplomatic facilities may be under increasing attack, and states may be party to some of those attacks, but paradoxically the institution of diplomacy quite clearly is not. A greater danger would appear to arise from the over-reaction of some states to these attacks.

73 'United Nations General Assembly: Resolution on the Consideration of Effective Measures to Enhance the Protection, Security and Safety of Diplomatic and Consular Missions and Representatives' (December 1980), in Friedlander, Vol.3, p.259. 


\title{
Chapter $\mathrm{V}$ \\ THE RESULT
}

The Challenge to Diplomacy

\begin{abstract}
All government, indeed every human benefit and enjoyment, every virtue, and every prudent act, is founded on compromise and barter.
\end{abstract}

Edmund Burke

Speech on conciliation with America

(1775)

Since terrorist attacks on diplomats and diplomatic facilities first reached serious proportions some fifteen years ago, diplomacy has been described as one of the world's most dangerous professions, ${ }^{1}$ with diplomats the 'front line fighters' 2 in 'a new kind of warfare' ${ }^{3}$ that has placed the entire system of diplomatic representation and peaceful negotiation 'under siege'. 4 The concept of diplomatic immunity is said to have become 'an anachronism' 5 and United Nations Secretary-General Kurt Waldheim described the occupation of the US Embassy in Tehran in 1979 as 'the most serious threat to world peace since the Cuban missile crisis'. 6 More recently, the Reagan Administration has claimed that

\footnotetext{
1 Wilkinson, 'After Tehran', p.5.

2 Richard Clutterbuck, Living with Terrorism (Faber, London, $1975)$, p.33.

3 'Embassies Under Siege', Newsweek, p.146.

4 Palliser, in Bull and Watson, p.372.

5 Bell, A Time of Terror, p.64.

6 Quoted in Aston, p.1.
} 
terrorists and their state sponsors have consciously set out to destroy diplomacy itself:

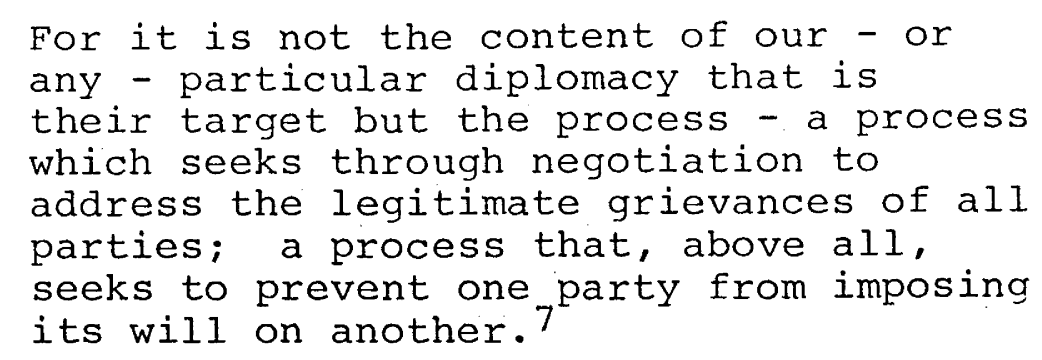

The 'instruments of diplomacy' are cited as 'the prime targets of terror'. 8 official Us statements have cast the fight against terrorism in apocalyptic terms with the US, on behalf of the world's democracies, defending a system that promotes the peaceful settlement of disputes against these 'depraved opponents of civilisation itself'.9

It is certainly true that diplomats now probably face a greater danger than has been faced by members of their profession since the sixteenth century. From the late 1960s, when attacks on diplomatic targets were found to be a powerful weapon of publicity and public extortion, the number of terrorist incidents involving diplomats has steadily grown, increasing dramatically with the arrival of the 1980s. Diplomats and diplomatic facilities now constitute the most favoured targets for terrorist attack. 10 This threat and the measures taken to guard against it have constrained diplomatic personnel in the performance of their duties and presented governments with a complex and delicate problem for the continued conduct of world diplomacy. In addition:

\footnotetext{
7 Dam, 'Terrorism in the Middle East', p.2.

8 ibid. See also Sayre, 'International Terrorism: A Long Twilight Struggle', p.2. It should be noted, perhaps, that the 'instruments of diplomacy' to which the us government refers include US, French, and even Israeli troops in Lebanon.

9 Shultz, 'Terrorism and the Modern World', p.2. 10 Patterns of International Terrorism: 1981, p.10.
} 


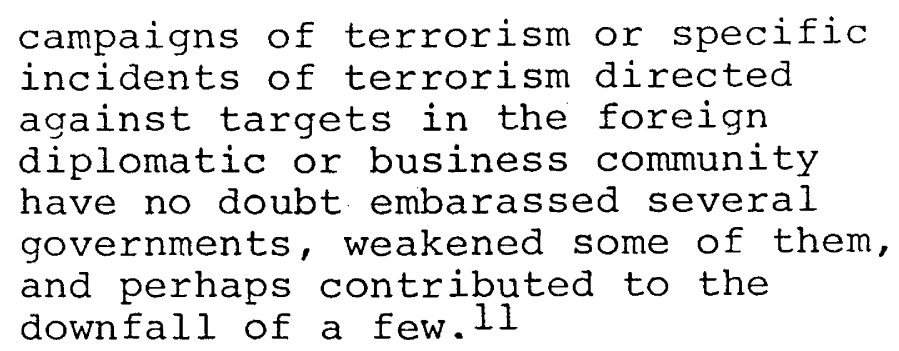

Attacks on diplomatic targets have caused friction between states, disrupted their economic relations and in some cases threatened their national sovereignty and territorial integrity. The emergence of such violent independent actors on the world scene has also presented a challenge to international order by striking at 'one of the most basic presuppositions of the states system, which is that only states may legitimately employ violence against each other, and then only in accordance with prescribed rules and procedures'. 12 The nature of modern society, the motivations of terrorists and their new capabilities give them the potential to become a real peace-keeping problem.

To assess the full impact of terrorism on diplomacy, however, these developments must be considered in the broadest perspective. Since 1945 the number of states has more than trebled, with the main increase being from four to over fifty in Africa and from nine to over forty in Asia. While the newly-constituted states represent a wide range of political and socio-economic systems, they share an acceptance of the concepts, developed under the European states system, of external sovereignty, territorial integrity and the legal equality of states. Yet if the concept of the sovereign state has not been challenged, European approaches to other matters have. Established attitudes to questions of legitimacy and self-determination, social, economic and political rights have

\footnotetext{
11 Jenkins, in Carlton and Schaerf, p.25.

12 Hedley Bull, 'Civil Violence and International Order' in Civil Violence and the International System, Part 2, p.31.
} 
increasingly come to be questioned by states and independent groups alike. To this mixture has been added the yeast of powerful religious and ideological movements. No longer do a relative handful of states make the rules and no longer do states necessarily feel bound by them. ${ }^{13}$ As pressures for change have mounted, so solutions have been sought outside customary fora. With the loosening of controls has also come the appearance of non-state actors with increased capacities to affect the international system. Many traditional restraints have been set aside and institutions which were formerly inviolate have become legitimate targets. Increases in terrorist attacks on diplomatic targets and abuses of diplomatic conventions have many causes but must be considered first in the light of these developments and the low consensus which currently prevails in many areas of world affairs. It can be argued that such developments are as much the symptoms of current international uncertainties as they are the causes of them.

It also needs to be remembered that, despite some dire predictions, no international terrorist group has yet managed to proceed beyond minor tactical successes and achieve its strategic objectives. The PLO has come closest but although it has secured a broad international commitment to a separate Palestinian state it does not seem very much closer to achieving one. With the possible exception of Uruguay between 1969-1972, the only governments which have fallen through terrorist action have been colonial regimes in circumstances where special conditions prevailed. 14 Indeed, as Andrew Mack has argued, terrorist action has tended to strengthen the state vis-a-vis civil society. ${ }^{15}$ No government with a genuinely

13 B.M. Jenkins, 'When the Yellow Ribbons Fade', Newsweek, 9 February 1981, p.19.

14 Wilkinson, Terrorism and the Liberal state, pp.50-51 and Andrew Mack, 'The Utility of Terrorism', Australia and New Zealand Journal of Criminology (December 1981), pp.211-216. 15 Mack, p. 199. 
popular support base has tolerated terrorism for long. With one or two exceptions no major political changes have occurred as a result of pressure from international terrorism. ${ }^{16}$ Paul Wilkinson put the problem into perspective when he wrote that:

it is manifestly improbable that tiny
bands of francs-tireurs, however
desperate, could seriously threaten
an international order dominated by
super powers with their vast military
strength and global capabilities...
The most they can hope to achieve is
the sowing of disruption and alarm,
or the temporary interruption or
exacerbation of diplomatic relations
between states.17

As Lenin, Mao Tse-tung, Guevara and others foresaw, terrorism has been able to attract a good deal of attention, obtain a number of minor concessions from states and force a number of changes to the day-to-day operations of international society, but has been unable to affect its vital functions. These functions include interstate exchanges through diplomatic intermediaries.

It is salutary too to look at the casualties that have resulted from attacks on diplomats and diplomatic facilities. Between 1968 and 1982, there were 381 diplomats killed and 824 wounded in terrorist incidents involving diplomats. 18 Twenty three of those killed were ambassadors. 19 Even when the numbers killed and injured in attacks over the past two years are included the total is unlikely to exceed $500 \mathrm{killed}$ and 1,000 injured for the whole fifteen year period. Tragic

16 In september 1973 the Austrian government, under pressure from Palestinian terrorists, agreed to stop allowing Jewish refugees from the Soviet Union to transit through Austria on their way to Israel. Wardlaw, Political Terrorism, p.40.

17 Wilkinson, Terrorism and the Liberal State, p.196.

18 Perez, 'Terrorist Target: The Diplomat', pp.1-2.

19 Terrorist Incidents Involving Diplomats, pp.3-4. 
though these figures are, they must be balanced against the total number of diplomats serving throughout the world during the same period who suffered no attack, making the number of casualties appear much smaller. The fact that two ambassadors at least were killed in civil wars is a reminder that diplomacy has always had its risks, even before terrorists posed a danger. ${ }^{20}$ Surveys conducted by the Rand Corporation, of embassy seizures and international hostage 'situations', suggest that in fact the number of deaths at the hands of terrorists (in the incidents surveyed at least) have been relatively small. Most people killed or injured were hurt either resisting the initial seizure or as a result of rescue operations by security forces. ${ }^{21}$ Since these studies were made, terrorist attacks have become more violent, resulting in a higher rate of casualties, but terrorism is primarily symbolic violence - violence for effect - with political consequences that invariably exceed the actual amount of death and destruction caused. Fewer than 20 per cent of all attacks on diplomats before 1982 resulted in casualties. Most terrorist groups 'want a lot of people watching and a lot of people listening, and not a lot of people dead'. ${ }^{22}$ The exalted status of the diplomat in the eyes of the public, the dramatic nature of the attacks, political rhetoric, unreliable statistics and the news media coverage inevitably given to such events have all combined to give a misleading impression of the scale of terrorist attacks on diplomats and their facilities. This is not to underestimate the threat, which is real, simply to put it into a proper context.

Paradoxically, while the number of attacks on diplomatic targets is increasing, the institution of diplomacy is becoming

\footnotetext{
20 Laqueur, Terrorism, p.273.

21 Jenkins, Numbered Lives, p. 2 .

22 Jenkins, in Carlton and Schaerf, p.15. See also Jenkins, Diplomats on the Front Line, p.7.
} 
more secure. Terrorist attacks upon diplomats and diplomatic facilities, whether carried out by independent groups or as an extension of state policies, have almost without exception been aimed in the first instance at states - most often the sending state, but also the receiving state, or both. At times, attacks have been indirectly aimed at other states but diplomatic targets have invariably been chosen by terrorists because they are state symbols, representing the governments, policies or political systems of states. Only very rarely, if at all, have they been attacked because they represented the diplomatic system as such. 23 Indeed, the only terrorist groups which have claimed to oppose world systems of this kind have been anarchist-nihilistic groups like the Angry Brigade in Britain, the Baader-Meinhof Group in Germany - to which all politics was 'shit'24 - and the Japanese United Red Army, which seems inspired by some vague notion of world revolution through indiscriminate violence. These groups have not often attacked diplomatic targets, though, and when they have their demands have been (like other groups) for the release of prisoners and monetary ransom, as in the case of the attack on the FRG Embassy in Stockholm by the 'Holger Meins Kommando' in April 1975 and the URA seizures of the French Embassy in The Hague in September 1974 and the Consular section of the US Embassy in Kuala Lumpur in August 1975. 25 At no stage have such groups claimed they were striking a symbolic blow at diplomacy, or even the diplomatic services of particular states. Diplomatic targets have always served as a means to a variety of tactical ends, never as ends in themselves.

Another reason why the institution of diplomacy is secure, even if its practitioners and premises are not, is that

23 Brian Jenkins has surveyed the nature of terrorists' demands in his studies Embassies Under Siege (pp.13-15) and Numbered Lives (p.2).

24 Jillian Becker, HitZer's Children (Granada, London, 1978), p. 90 .

25

Details of these incidents are given in B.M. Jenkins and J. Johnson, International Terrorism: A Chronology, 1968-1974, Rand Report R-1597-DOS/ARPA (Rand Corporation, Santa Monica, 1975). 
terrorists are usually alive to the role that diplomacy can play in the realisation of both their tactical and strategic goals. The kidnapping of diplomats and the seizure of diplomatic facilities in one sense represents a flat rejection of the diplomatic option of peaceful negotiations and compromise, yet such attacks are not quite the 'zero sum' game that Paul Wilkinson has suggested. 26 They give the terrorists a bargaining position in which they achieve diplomatic leverage infinitely greater than would otherwise be obtainable. Like states wielding power in a more conventional negotiation the terrorists become party to a 'coercive value exchange' 27 in which the diplomatic representatives of other countries are inevitably involved. States sponsoring terrorist groups utilise the same principles at a national level, in conducting their own 'coercive diplomacy'. On at least two occasions terrorist demands have been for certain states to break diplomatic relations. Terrorist groups no longer seem anxious to woo international opinion in the manner of guerrilla forces in the past, but they have been quick to realise that even a negative impact can mobilise opinion and win them certain concessions. 'While terrorists attack the basic rules of international order, they depend on international pressure to achieve their political goals'. 28 This has been most apparent in the case of various Middle Eastern terrorist organisations, such as the PLO.

The example of the PLO points to yet another paradox, which is that many terrorist groups, including those which attack diplomatic targets, seek the legitimacy that diplomatic status represents. This can be achieved either as a terrorist

26 wilkinson, Terrorism and the Liberal State, p.179.

27 Aston, p.5.

28 Jenkins, in Carlton and Schaerf, p.24. 
organisation, or as a state. The PLO has managed the former and enjoys formal observer status at the UN, membership of several important international organisations and full representation at a number of major conferences. In addition, the PLO maintains its own 'diplomatic service' with offices in over 100 countries, where they are accorded full, or near full, diplomatic privileges. ${ }^{29}$ Since 1973 the world has been treated to the irony of the moderate, and now 'respectable', factions of the PLO seeking 'diplomatic' solutions and denouncing the 'reckless and irresponsible' acts of international terrorism carried out by other Palestinian groups, 30 all of which strongly suggests that the main Palestinian factions at least wish to gain more power within the international system without undermining its foundations. The other avenue to diplomatic status is through having successfully achieved statehood. In some cases this aim is held largely because the easiest way to instigate desired changes in a state or world of states is to seize control of such a unit. 31 In other cases a state of their own is the ultimate aim of many terrorist groups, particularly those with ethnic, religious or other separatist ideologies. It is perhaps not stretching this argument too far to see in the 'anti-diplomatic corps' which existed in Algeria in the early 1970s a recognition by terrorist groups that some kind of diplomatic intercourse will always be necessary. 32

The greatest danger terrorism poses for diplomacy lies in the blatant disregard for diplomatic norms shown by some states and their use of agitational terror as extensions of

29 Christopher Dobson and Ronald Payne, The Weapons of Terror, p. 83 .

30 S.J. Rosen and R. Frank, 'Measures Against International Terrorism', in Carlton and Schaerf, p.63. Yasser Arafat made considerable efforts to persuade the $B R$ to release Aldo Moro in 1978. (Moro was considered sympathetic to the Palestinian cause.) See Katz, pp.295-296.

31 Bell, in Keohane and Nye, p.167.

32 Geoffrey McDermott, The New Diplomacy and its Apparatus (Plume Press, London, 1973), p.67. 
their foreign policies. Such behaviour has the potential seriously to undermine not only the established conventions through which states regulate their contacts with each other, but the whole rule of law on which such contacts are based. Once again, however, these developments in themselves are not new and while a few mavericks like Iran and Libya have shocked the world with their rejection of customary standards even they have not rejected diplomacy outright. Iran's unprecedented abrogation of its responsibilities towards the US mission in Tehran was universally condemned, including by all members of the Security council and by a number of states which might have been expected to sympathise with the revolutionaries. 33 Yet the Iranians themselves continued to operate their diplomatic missions abroad and to accept all the usual courtesies from receiving governments. They also 'carefully respected the immunities of other embassies and of the diplomatic emissaries who negotiated the eventual release of the hostages'. ${ }^{34}$ In 1979 Libya loudly rejected conventional diplomatic forms, much as the Soviet Union had done in 1918,35 and has since demonstrated its contempt for all standards of civilised behaviour by the shooting of a policewoman in St. James' Square. Despite its behaviour in some states, however, Libya seems prepared to abide by

33

Watson, p.140. According to William Gutteridge, the US National Security Advisor summoned the Libyan Ambassador to Washington in December 1979 and asked his government to intercede on behalf of the US hostages in Iran. Colonel Qaddafi promised he would try and sent a delegation to Tehran. Apparently, the Libyan approach was rebuffed by the Khomeini regime. Gutteridge, p.18.

34

Watson, p.140.

35

By a decree on 4 June 1918 the new Soviet government recognised the 'complete equality of great and small nations', abolished the titles and ranks of ambassador and minister and substituted 'plenipotentiary representative', or polpred, for short. E.H. Carr, The Bolshevik Revolution 1917-1923, 3 Vols. (Penguin, Harmondsworth, 1983), Vol.3, p.78. 
customary rules in others and there are signs that its experiment with Peoples' Bureaux is fast crumbling away. 36

As states which supported terrorism in one form or another have themselves come under terrorist attack, they have been quick to reaffirm the value of traditional norms of international conduct. The seizure of the Saudi Arabian Embassies in Khartoum and Paris in 1973, for example, prompted a rapid reassessment of saudi (and somali) attitudes towards terrorism and the financial aid Saudi Arabia was giving to the Palestinians. European states like France which, while not actually condoning terrorism had at least taken a permissive view of terrorist activities against other states, have responded quickly and firmly when their own sovereignty has been impugned. ${ }^{37}$ As the scope of terrorism has become wider even some of the more radical states have begun to take a less sympathetic view of certain types of terrorist operation. In particular, since the massive increase in attacks against diplomats and diplomatic facilities in the early 1980s:
a growing number of states have seriously questioned whether the pursuit of anti- colonialism and self-determination really necessitates the abandoning of traditional standards, of state behaviour. The consensus among states seems to have moved towards

\begin{abstract}
36 In a personal interview with the Information officer of the Libyan Peoples' Bureau in Canberra in June 1984, the author was told that Libya was most unhappy with the fact that the Secretaries of their overseas missions are only accorded a rank equivalent to that of Charge d'Affaires. Although Libya rejects the formal title of Ambassaddr it is apparently felt that this would be a more appropriate rank to accord their senior representatives abroad and Libya is currently pursuing the matter in the context of the vienna Conventions.
\end{abstract}

37 Moxon-Browne passim and Wardlaw, 'Terrorism: How big a threat to peace'. See also Political Violence and Civil Disobedience in Western Europe, 1982, Conflict Studies 145 (Institute for the Study of Conflict, London, 1983), p.2. 
rejection of those forms of political expression which violate such basic trust. 38

This consensus is demonstrated most clearly by the unanimous support given in the United Nations and other international organisations to measures aimed at safeguarding internationally protected persons.

While discussions on terrorism in international fora have revealed deep and apparently irreconcilable divisions over the nature of the phenomenon and the responses that states should make to it, they have also revealed a remarkable community of shared values and interests regarding the need to protect diplomats and diplomatic facilities from terrorist attack. Not even token dissent has been registered on this fundamental issue in all the times it has been raised over the past fifteen years. While questions of principle have figured prominently in most public speeches on the subject, such consensus would only be possible if all states recognised that the continued functioning of diplomacy served their own vital interests and that, as noted in the 1961 Vienna Convention, such functions can only be carried out if certain privileges and immunities were respected. All states appear to have accepted that they are equally vulnerable to such attacks. As Grant Wardlaw has pointed out, the nature of international terrorism is likely to mean that attempts at a global level to control these attacks will tend to focus on legal obligations rather than practical measures. 39

38 Wardlaw, 'Terrorism: How big a threat to peace', p.13. Not even the most radical states have escaped attacks on their diplomats and diplomatic facilities. The Syrian Embassy in Rome was seized by terrorists in 1976, the Iraqi Embassy in Paris was seized in 1978 and the Iranian Embassy in London was taken over in 1980. The Libyan Embassy in Beirut has been blown up by a bomb and two Libyan diplomats abducted by radical Shiite Muslims. The Iraqi Embassy in Beirut was also bombed in 1981, leaving 20 dead and 100 injured. 
International legal measures of this kind will probably always lack effective sanctions and be subject to abuse but it is sufficient for the purposes of this study that states have demonstrated so clearly their willingness to develop a more elaborate body of international law on the subject of terrorist attacks on diplomats and diplomatic facilities. With each additional instrument the importance of diplomacy is underscored and the likelihood diminished that the institution itself will come under serious threat.

If these arguments are accepted, then it can be cliaimed that while diplomats and diplomatic facilities are facing increasing dangers from international terrorism, the institution of diplomacy is not. Both the terrorists and the states which support them recognise the continuing value of diplomacy and have made plain their feeling that it should be preserved. This is a fine distinction, and one that offers cold comfort to the diplomats and governments at risk. It is an important distinction, however, for from it flows an estimation of the scope and true nature of the threat posed to the international system by terrorism and the measures states need to take to respond to it. It is an important distinction too for the perspective it gives to the Reagan Administration's insistence that the world's current terrorist problem springs from the Soviet Union's desire to 'weaken liberal democracy and undermine world stability'. 40 For if, as the Us claims, international terrorists are attacking the institution of diplomacy - 'the process' - and the terrorists are ultimately controlled from Moscow, then it follows that the Us is accusing the Soviet Union of attempting to undermine the institution of diplomacy. Yet, for all the Soviet Union's involvement with international terrorism over the past fifteen years, this is clearly not the case.

While the Soviet Union has shown little hesitation in using terrorist groups to weaken the capacities and resolve of

40 Shultz, 'Terrorism: The Challenge to the Democraciè', p.3. 
the West, particularly in areas of strategic importance like the Middle East, it has consistently displayed an ambivalence about certain kinds of terrorist operation. 41 It has had to balance its interests in supporting anti-Western forces with opposition to terrorist activities and policies to which the Soviet union itself is vulnerable, such as attacks on diplomats and diplomatic facilities. While it is true there are few terrorist incidents reported in. Eastern bloc countries, after the US, Turkey, Yugoslavia and France, Cuba and the USSR are the victims of the greatest number of terrorist attacks against diplomatic targets. In addition, Soviet casualties from terrorist attacks have been exceeded only by US and Israeli casualties, a fact apparently forgotten by the Reagan Administration despite the fact that a significant proportion of these incidents occurred in the United States. 42 The Soviet Union places as much value on its diplomatic processes as other states and thus shares with them an interest in seeing greater protection given to diplomats and their facilities. As early as September 1972 Soviet Foreign Minister Andrei Gromyko told the United Nations General Assembly that:

On the basis of positions of principle, the Soviet Union opposes acts of terrorism which disrupt the diplomatic activities of states and their representatives, transport communications between them and the normal course of international contact and meetings, and it opposes acts of violence which serve no purpose and cause loss of human life.43

The leader of the Soviet delegation emphasised this point when he told the same session of the UN that the Soviet Union was opposed to terrorism 'particularly violent acts committed

\footnotetext{
41 See for example Robert Freedman, 'Soviet Policy Toward International Terrorism' in Alexander, p.133 and p.142.

42 Terrorist Incidents Involving Diplomats, p.3 and Jenkins, Diplomats on the Front Line, p.5.

43

Quoted in Thompson, p.1285.
} 
against heads of state and diplomats in foreign countries'.44 As W.S. Thompson has correctly observed, these are precisely those functions of inter-state relations in which the USSR has almost as much at stake as any other country. 45

For all their posturing on other matters related to terrorism, these and similar statements do not seem to be simply rhetoric on the part of the Soviet Union and its allies. They were among the first states to become party to the UN Convention on the Prevention and Punishment of Crimes Against Internationally Protected Persons, Including Diplomatic Agents, a step yet to be taken by a number of the us's NATO allies. 46 There is evidence to suggest that at various times the Soviet Union has attempted to restrain terrorist groups over which it exercises some influence and at times it has supported anti-terrorist measures in international fora which have been opposed by its terrorist clients. 47 In addition, there have been a number of examples of East-West cooperation to prevent attacks on diplomats and the hijacking of aircraft. The Soviet Union's security services enjoy a close working relationship with the US secret Service over the protection of Soviet officials in America. The Cuba-USA Memorandum of Understanding on the Hijacking of Aircraft and Vessels and Other offences is a remarkable example of how two states with widely varying attitudes on other matters can cooperate when they perceive shared interests. 48 The Soviet Union shared a

44

Quoted in Freedman, in Alexander, pp.131-132.

45

Thompson, p.1285.

46

France, Belgium and the Netherlands, for example, have yet to become parties to the convention. See 'Treaties and Conventions Relevant to International Terrorism', Terrorism: An International Journal 7:2 (1984), p.136.

47 Freedman, in Alexander, pp.122-123. Stephen Clissold has also claimed that the Soviet Union rebuffed advances from Croatian separatists in Australia in the late l970s (Clissold, p.17).

48 As Rosen and Frank describe it, the US-Cuba agreement represents a remarkable 'obligation by a militant socialist state to extradite and subject to prosecution opponents of the world's leading imperialist state'. (Rosen and Frank, in Carlton and Schaerf, p.62.) The fundamental factor, here as elsewhere, is a common interest which outweighs ideology and short-term political gain. 
similar agreement with the Shah's Iran and has since given some practical assistance to the FRG on matters relating to the hijacking of aircraft. ${ }^{49}$ Even Bulgaria, implicated in the attempted assassination of the Pope in May 1981, 50 assisted in the capture of a number of international terrorists and their extradition to the FRG for trial in 1978 .

This cooperation with the West has not stemmed from any altruism or allegiance to the sanctity of traditional diplomacy. Indeed, there is no place for international commerce, interstate diplomacy or even sovereign states themselves in the world order ultimately envisaged by orthodox Marxist ideologues. It is recognised, however, that all three are unlikely to disappear in the foreseeable future and that the interests of the Soviet Union and its allies currently lie in accepting these realities and utilising them for their own benefit. Given the Soviet Union's investment in this system, any attack which seriously threatens it is likely to be to the detriment of the Soviet Union as much as, if not more than, other states. As Adam Watson has stated in a wider context, both the superpowers have so far recognised, explicitly or tacitly, that:

the preservation and effective functioning of their system and of international society must be given priority whenever the point is reached where it appears to be seriously threatened. This attitude is something more than prudence and restraint. It is a conscious raison de systeme, the use of diplomacy to achieve the ultimate purpose of an international society of independent states. 51

The Soviet Union does not appear ready to sacrifice the advantages its influence with terrorist groups currently gives

49 Peter Koch and Kai Hermann, Assault at Mogadishu (Corgi, London, 1977), p.76.

50

Los Angeles Times, 30 January 1983, p.1.

51 watson, p.203. 
it, but it does seem anxious to preserve the vital elements of this system. From its statements over the past four years, however, the Reagan Administration appears to feel that the USSR has abandoned any interests it may have had in the existing world system and chosen instead to undermine it through terrorist surrogates. In terms that US officials have long applied to communism itself, terrorism is described as a 'contagious disease' that will ultimately destroy 'civilisation itself'.52 Terror and counter-terror have been cast in terms of an epic struggle between anarchy and civilisation, totalitarianism and democracy, extremism and moderation, violence and diplomacy. ${ }^{53}$ This apocalyptic vision has consequences that reach well beyond the spheres of terrorism and state responses to it.

By concentrating upon international terrorism as political acts, rather than looking at the political, social and economic context in which it has arisen in various parts of the world, the US appears to have ignored the real complexity of the terrorist problem and obscured the root causes of much extremist discontent. By overlooking the US's own support for terror now and in the past, and by failing to see contemporary terrorism in a wider historical perspective, the Reagan Administration has also tended to view the current terrorist threat as something newer and more threatening to world order than appears to be the case. This is not to underestimate the dangers posed by terrorism today, but to argue against an over-reaction which could be far more destabilising than the problem which it is hoped to solve. Recent US government statements remove the terrorist problem from the political arena by stressing its essential criminality, but at the same time place it firmly on the political agenda

\footnotetext{
52 Shultz, 'Terrorism and the Modern World', p.8.

53 See for example Dam, 'Terrorism in the Middle East', p.2. This point is made in greater detail by Schlesinger, Murdock and Elliott, p.l.
} 
by treating it as a matter for global concern. 54 International consideration of the terrorist problem is necessary and, as demonstrated by the New York Convention on the protection of diplomats, occasionally successful in focussing attention on areas of universal concern. By presenting the terrorist problem as a major factor in the East-West struggle, however, the Reagan Administration has publicly locked this entire, complex and highly sensitive issue into the wider competition between the superpowers. Attempts by the US and USSR to legitimise their own policies and delegitimise those of their opponent thus become of paramount concern and the deeper causes of terrorist violence, and the measures necessary to prevent it, become increasingly obscured. Terrorist attacks all over the world are perceived by the US as Soviet tests of its resolve and in order to maintain a reputation for strength, preserve its international prestige and keep its credibility with its allies the Us has felt obliged to make a strong response. Unable to score any major political successes, however, the Reagan Administration has increasingly turned to military options.

In an address before the Park Avenue Synagogue in October 1984, US Secretary of State George Shultz said that:

the essence of our response is simple to state: violence and aggression must be met with firm resistance ... there is no question about our ability to use force where and when it is needed to counter terrorism. Our nation has forces prepared for action - from small teams able to operate virtually undetected, to the full weight of our conventional military might. 55

On another occasion Mir Shultz referred to international terrorism and spoke of the US's readiness to 'resort to arms on behalf of democracy against repressive regimes and

\footnotetext{
54 Schlesinger, Murdock and Elliott, p.2.

55 Shultz, 'Terrorism and the Modern World', p.15.
} 
movements'.56 These strong statements were doubtless designed in part to reassure the American public and signal to foreign governments the US's strength and resolve in the face of continued terrorist provocation. Yet whether or not they reflected a serious commitment to. direct action, the Reagan Administration's policy of 'active defence' against terrorism constitutes a threat to international order and world peace as great as that posed by terrorism itself. For, if Mr shultz's speeches are found to be mere rhetoric, or if such policies were discovered not to be feasible and abandoned, the credibility of the US would be greatly diminished and, by extension, the cohesion of the Western alliance would be weakened. If these policies were seriously pursued, on the other hand, their consequences would be even worse. A military response of the kind being considered would clearly have little significant impact on the terrorist problem. It 'would only succeed in substituting the greater evil of full-scale war... for the lesser evil of terrorism'.57 As Carlos Marighela instructed his proteges they should do in 1969, the terrorists will have succeeded in turning a political problem into a military one, except that in this case it is not the armed forces of a single developing country that is involved, but the full conventional military might of the world's greatest superpower, operating on a global scale. 58

Just as assassinations, kidnappings and torture by counterterrorist units have already done on a smaller scale, the kind of response being considered by the US would also serve to undermine the very codes of behaviour and international legal institutions which the Reagan Administration claims to defend. This would have consequences reaching far beyond any

\footnotetext{
56 Shultz, 'Terrorism: The Challenge to the Democracies', pp. $2-3$.
}

57 Wilkinson, 'state-sponsored international terrorism: the problems of response', p.298.

58 Marighela, 'Problems and Principles of Strategy' in For the Liberation of Eraziz, p.46. 
terrorist campaign. International law is already a fragile institution. It relies on the voluntary compliance of states, in particular the observance of certain principles and procedures by the most influential states in world affairs, namely the superpowers. Thus the us shares a heavy responsibility for the continued workings of international diplomacy and other legal mechanisms which regulate and encourage peaceful contacts between states. 59 Should the US abandon these norms and resort to tactics similar to those used by the terrorists and their state sponsors, then the entire structure of ordered international society - including diplomacy as it is now known - will be threatened to a greater degree than it is by terrorism already. ${ }^{60}$ There is a real dilemma for the US here. It claims to cherish 'a world based on the rule of $1 \mathrm{aw}^{.61}$ yet it is prepared apparently to flout that law in the name of preserving it. Terrorists are not vulnerable to moral force or to international laws in the manner of states and can thus violate accepted behaviour in the way that states like the us cannot. This asymmetry is exploited by terrorists and their sponsors, yet unless the disadvantages of this situation are accepted and the distinction between states and terrorists is preserved, the entire rule of law is undermined and the international order gravely destabilised. 62 In this sense David Fromkin is correct in saying that terrorism 'achieves its goals not through its acts but through responses to its acts'.63

The conviction that international terrorism is essentially a form of surrogate warfare conducted by the Soviet Union appears to have led the Reagan Administration not only

59 watson, p.40 and p.197.

60 Wilkinson, Terrorism: International Dimensions, p.4.

61 Shultz, 'The Challenge to the Democracies', p.2.

62 Jenkins, in Carlton and Schaerf, p.27.

63 Fromkin, p.692. 
to believe that terrorism can be defeated by an equal or greater application of military force, but also that the US can 'eventually stamp it out'. 64 Even allowing for the exaggeration usual in public statements of this kind, the whole thrust of the US's latest counter-terrorist program is towards defensive measures against terrorist acts and offensive measures against terrorist groups. Despite all the evidence to the contrary there still seems to be a conviction in American political and military circles that unconventional conflicts can be overcome by these measures alone. This approach suggests either a profound misunderstanding of the nature of terrorist violence or an excessive confidence in the capabilities of the US, or both. It also suggests an inability or unwillingness on the part of the American government to consider ways of preventing terrorism at its source. Increased protection against attacks, international cooperation and the capability to respond to particular incidents are all important, but none address the objective causes of terrorism which tend to be found in ideological and religious convictions, political, social and economic discontent. As has been demonstrated in numerous unconventional conflicts since 1945, many of which included American participation, unless these issues are addressed little progress can be made towards a lasting and peaceful solution. $6 j$

Some terrorists may have goals that are attainable in the long term but it is unlikely that states will ever be able to eliminate all sources of discontent, many of which have already been examined by national governments, regional organisations and the United Nations and found to be intractable. As Raymond Aron has said, 'he is not conquered who does not

64 Shultz, 'Terrorism and the Modern World', p.8.

65 This subject has been addressed by Andrew Mack, 'Why Big Nations Lose Small Wars: The Politics of Asymmetric Conflict', World Politics 27:2 (January 1975). 
admit defeat' 66 and there will always be irreconcilable elements prepared to resort to violence. It must be recognised too that the distinctions between psychopaths, idealists, independent groups and state-sponsored groups are becoming increasingly blurred, as are the forces motivating them. To a degree, terrorism has become institutionalised, an integral part of the international system that is 'simultaneously combatted, tolerated, and exploited 167 by states, in much the same way piracy was in earlier times. Emphasis is given to particular aspects of the terrorist problem as it suits a state's perceived national needs at the time. This is not to suggest that the quest for a solution to the problem of international terrorist violence should be abandoned, simply that any solution is likely to be imperfect and a long time coming. The need is for continued quiet diplomacy, moderate international initiatives and more imaginative solutions. Greater consideration could be given to the use of collective sanctions against states sponsoring terrorism and stronger reciprocal action in response to abuses of diplomatic privileges. Above all, a greater effort must be made to rebuild the confidence of state and non-state actors alike in diplomatic processes as the best means fairly and sympathetically to manage change. In this the role of the superpowers will be crucial, for unless they show a greater willingness themselves to place faith in negotiations and to abide by the conventions of diplomatic behaviour it is unrealistic to expect other states and non-state actors to do so.

States cannot afford to be sanguine about the problems posed by international terrorism, but terrorist attacks on diplomats and diplomatic facilities should not, as Michael Palliser has warned, be allowed to induce the belief 'that a

66

Aron, p.25.

67

Jenkins, New Modes of Conflict, p.14. 
code of practice which has developed over the centuries, and which for the most part works well, is in imminent danger of collapse'. ${ }^{68}$ It clearly is not. By its very nature diplomacy has been able to adapt itself to changing world conditions, accommodating new requirements and meeting fresh challenges. In some respects there has been a decline in the role played by traditional diplomacy in international politics, but the institution continues to flourish. Those revolutionary regimes which initially rejected conventional diplomatic processes, such as Russia and Libya, quickly found that they could not dispense with them and still live in a plural yet ordered society of states. ${ }^{69}$ Even if resident embassies should lose their importance or are transformed in character, states will continue to negotiate solutions to their problems, just as they did before the emergence of resident embassies and professional diplomatic services. 70

International society today is highly mobile, with power distributed among a number of centres. Even the smalles: state can quickly assume global significance. Technological developments have made all states vulnerable to an unprecedented degree and safety can no longer be seen to lie in alliances or military strength. In such a situation not even the most powerful country can afford to ignore certain principles of statecraft. In addition, both state and nonstate actors are growing in number and becoming more interdependent. World politics is becoming increasingly complex and no state can isolate itself without harm to its own interests. This places a high premium on diplomatic contacts and skills. Diplomacy remains 'at bottom, the communications system of international society' 71 and in the

68 Palliser, in Bull and Watson, p.352.

69 Bull, The Anarchical Society, p.173 and Keens-Soper, p.914. 70 watson, p.11.

71 James, p.942. 
current international environment continues to play a vital role. Periods of low consensus, as now, serve only to emphasise that conflicts of interest are a major preoccupation of diplomats and, short of war, can only strengthen their traditional role.

In another sense too, it can be argued that diplomacy thrives on discord. Throughout history it has emerged from periods of heightened international competition stronger than before. The Peace of Westphalia in 1648 was negotiated at the end of the Hundred Years War, the Congress of Vienna in 1815 took place during the Napoleonic Wars which convulsed the old World and the 1961 Vienna Conference was held at the height of the Cold War. It is possible that the 1973 New York Convention will come to be seen as this generation's response to threats to diplomacy in a post-colonial era of revolution and socio-economic discontent. These international meetings and the legal instruments which flowed from them are all illustrative of the enduring concern felt by states, particularly in times of danger, to preserve an institution vital to them all. For as long as states remain wedded to their own interests in a world system, diplomacy will be needed. It 'meets the great secular need of mankind, the need for peoples to make arrangements with each other'. 72

Naturally, there is cause for concern in the blatant disregard for diplomatic norms by some states - old and new and the use of diplomacy to excite differences rather than settle them, but despite the fond assumptions of Sir Harold Nicolson, George Kennan and others there has never been a golden age when diplomats were entirely free from danger, whether it be from individuals, groups or governments. 73 In

\footnotetext{
72 R.B. Mowat, Diplomacy and Peace (Williams and Norgate, London, 1935), p.199.
}

73 C.B. Marshall, 'The Golden Age in Pexspective', Journal of International Affairs $17: 1$ (1963), p.10 and Harold Nicolson, 'Diplomacy Then and Now', Foreign Affairs 1 (October 1961), p. 39 . 
addition, questions of power and prestige have almost always figured in international negotiations and the institution of diplomacy is not going to be unduly threatened if the unspoken fear behind an agreement is one of a terrorist bomb rather than the despatch of a gunboat or the launch of a nuclear missile. As Raymond Aron and Martin Wight have shown, diplomacy has never been pure ${ }^{74}$ and while continued efforts must be made to prevent abuses of the diplomatic system it should come as no surprise if they should still occur. There will continue to be challenges to the conventions of diplomacy and terrorist attacks against diplomatic targets will most likely increase before they diminish, 75 but diplomacy will survive as it has always done, insured against collapse by the recognition of all states that it continues to play a vital role in their affairs. Even if its component parts are threatened, the institution will remain secure, protected by established states and coveted by its attackers.

If terrorism will remain and diplomacy will survive, then it follows that the diplomatic profession will continue to be a dangerous one for the foreseeable future. Both sending and receiving states will need to give greater attention to the protection of diplomats and diplomatic facilities. Diplomats and their families too will need to accept that a career in diplomacy will expose them to the possibility of terrorist attack and while the risks can be reduced they can never be eliminated entirely. In these circumstances, perhaps the best that can be hoped for is that the terrorist problem can be managed in such a way that, like crime in the domestic context, the least harm is done to the fewest people, and that terrorism is not permitted to disrupt the normal functioning of international society.

74 Wight, pp.118-120 and Aron, pp.60-61.

75 'Embassies Under Siege', Newsweek, p.146. See also B.M. Jenkins, 'International Terrorism: Trends and Potentialities', Journal of International Affairs 32:1 (1978), pp.115-123. 


\title{
POSTSCRIPT
}

The extent to which Australia and Australians have suffered terrorism is small when compared with what has happened in other places. But however much the absence here of the grosser tragedies that other communities have had to suffer justifies a feeling of relief, it does not justify complacency.

\author{
Mr Justice R.M. Hope \\ Protective Security Review \\ (1979)
}

To date, Australia has been relatively free from the problem of terrorist attacks on diplomats and diplomatic facilities. Yet if this global threat to diplomats continues to grow, as seems likely, then it is equally likely that Australia as an active participant in the international system will not continue to enjoy its current good fortune. It is important, therefore, that the responsible authorities use the time now available to them to prepare for such attacks, both to Australian diplomats and diplomatic facilities overseas and to possible diplomatic targets in this country.

In March 1983, when Australian Foreign Minister Bill Hayden received a report from his Department on the safety of Australian diplomatic personnel overseas, he was reportedly 'stunned' at the high incidence of violent attacks upon them. I While few, if any, of these attacks appear to have been at the hands of terrorists ${ }^{2}$ there can be little doubt that, sooner or later, this situation will change. If not to apply pressure

1 'Diplomats face high risk, says Hayden' and 'Dangers of diplomacy', The Age 25 March 1983, p.3 and p.13.

2 'off the champagne trail: Diplomatic security abroad', Australian Foreign Affairs Record 54:5 (May 1983), pp.167-168. 
directly on the Australian government, Australian diplomats or diplomatic facilities overseas could be attacked to win concessions from a receiving state or other governments, in the way that the diplomats of other states have been made instrumental targets in the past. Also, as other countries improve the security of their missions abroad, so Australian posts may be viewed as relatively 'soft' targets through which demands can be made on Australia's friends and allies. As terrorist attacks increase in scope and frequency, so too will the possibility of Australian officials becoming incidental victims, as nearly occurred in 1984 when Irish terrorists attempted to assassinate British Prime Minister Margaret Thatcher. ${ }^{3}$ Canada's assistance to us diplomats in Tehran in 1979 was an exceptional case, but it is not inconceivable that at some time in the future Australia too may become involved in a terrorist attack upon the diplomatic assets of an ally.

As Peter Boyce has pointed out, 'what helps distinguish the latest form of guerrilla terrorism against diplomats is that such incidents are as likely as not to occur in countries which are not themselves direct targets of guerrilla violence, but merely hosts to embassies which are'. 4 The relevance of this observation to Australia has already been demonstrated by Mr Justice Hope's 1979 Protective Security Review. ${ }^{5}$ Since 1966 there have been bomb attacks on the

3 The Australian High Commissioner to the United Kingdom was staying at the same Brighton hotel as Mrs Thatcher, when it was destroyed by an IRA bomb. The High Commissioner escaped with shock and minor injuries. These points have also been made in Andrew Selth, 'Diplomacy under siege in the face of terror', Canberra Times 21 April 1985, p.5.

4

Boyce, p.213.

5 Protective Security Review: Report (Unclassified Version), Parliamentary Paper No.397/1979 (Australian Government Publishing Service, Canberra, 1979). 
diplomatic facilities of the United States, Yugoslavia, the Soviet Union and Israel in various Australian cities and violent attacks have been made on Indian and Turkish diplomats resident here. ${ }^{6}$ A number of these incidents appear to have been carried out by international terrorist groups. The Hope Report stated that diplomats based in Australia were likely to remain high priority targets for terrorists and that special measures were required to provide for their safety. ${ }^{7}$ In addition, it needs to be remembered that Australia has been used to train international terrorists for operations abroad 8 and has provided shelter for terrorists wanted elsewhere. ${ }^{9}$ There is evidence too that Australia has been chosen in the past as the possible site of attacks against diplomatic missions and visiting heads of state. ${ }^{10}$ At times these links with international terrorism have caused considerable friction

6 Although it is listed in Terrorism: An International Journal $6: 2$ (1982) as an attack by terrorists, the murder of the Greek Consul-General insydney in November 1981 appears to have been a criminal assault quite unrelated to terrorism.

Protective Security Review, p.24.

8 Stephen Clissold cites the case of 19 Croatian guerrillas trained in Australia and Germany who were infiltrated into Yugoslavia in 1972. They were quickly hunted down by the Yugoslav authorities, who killed 15 outright and executed 3 later. The last was sentenced to 20 years imprisonment. In 1978 Australian police surprised another 19 heavily armed Croatians allegedly 'making a film' while on their way to a training camp in New South Wales. As late as 1979 Croatian terrorist training camps were believed to exist in Australia. Clissold, pp.10-11.

9

A wanted member of the Baader-Meinhof Group was captured in Australia in 1981 by Australian and FRG police. See 'International Terrorism', Address by the Head, PSCC, to the Joint Services Staff College, Canberra, 22 February 1983, p.22.

10 Protective Security Review, p.23. It appears that the Yugoslav Prime Minister and the Japanese Prime Minister both faced a serious risk of international terrorist attack during their official visits to Australia in 1973 and 1974 respectively. Similar fears were held for the safety of the Turkish Foreign Minister, who visited Australia in April 1985. 
between Australia and other states, in one case almost leading to the severing of diplomatic relations. ${ }^{11}$

Australia has consistently supported international initiatives to protect diplomats and diplomatic facilities and has taken a number of significant steps to meet its international legal obligations in this regard. Australia has become full party to the United Nations Convention on the Prevention and Punishment of Crimes against Internationally Protected Persons, Including Diplomatic Agents, and in 1976 incorporated the entire convention into Australian law. ${ }^{12}$ In the same year the Protective Services Coordination Centre (PSCC) was established in Canberra to coordinate protective security arrangements for both Australians and visiting dignitaries and for countering terrorism in Australia, including attacks on diplomatic targets. ${ }^{13}$ PSCC shares close contacts with the Australian Security Intelligence Organisation (ASIO), relevant Commonwealth Departments, the Australian Defence Force and with Federal and State Police Forces. ${ }^{14} \mathrm{~A}$ National Anti-Terrorist Plan has been developed and endorsed by all levels of Australian government and counter-terrorist

11 According to the British scholar Paul Wilkinson, some Australian political leaders have chosen to turn a blind eye to Croatian terrorist groups and their activities in Australia. One Attorney-General is even alleged to have actively supported them because they were aggressively anti-communist. When a bomb exploded in the Yugoslav Travel Agency in Sydney in 1972 and 15 people were injured, however, the Yugoslav government threatened to break off diplomatic relations with Australia unless:a stronger stand was taken against Croatian extremists. Paul Wilkinson, Political Terrorism (Macmillan, London, 1974), pp. 150-151.

12 see the Crimes (Internationally Protected Persons) Act 1976. The 1961 Vienna Convention on Diplomatic Relations, with all its Articles relating to the inviolability of diplomatic agents, had been incorporated into Australian law in its entirety by the Diplomatic Privileges and Immunities Act 1967.

13 Protective Security Review, p.53. See also the Department of Administrative Services Annual Report 1981-82, p.54 and the Department of the $S$ pecial Minister of $S$ tate Annual Report 1982-83, pp.10-11.

14

Protective Security Review, pp.52-68. 
planning at the national level is examined and coordinated through the Standing Advisory Committee for Commonwealth/State Cooperation on Protection Against Violence (SAC-PAV). SAC-PAV was established in 1979 in the wake of the 1978 bombing incident outside Sydney's Hilton Hotel, where a Commonwealth Heads of Government Regional Meeting was being held. SAC-PAV is supported by a number of specialised working groups and subcommittees comprising representatives of all relevant Australian agencies. ${ }^{15}$ It has yet to be seen whether the creation of the Australian Protective Service in 1984, 16 which left responsibility for the protection of the diplomatic community in Australia completely in the hands of the Australian Federal Police (AFP), will increase the AFP's capabilities in this regard or, by competing for scarce resources, diminish them.

Curiously, although these steps have been taken within Australia, much less attention has been given to the protection of Australian diplomats and diplomatic facilities abroad. The funds allocated annually to the Department of Foreign Affairs for protective security, for example, have more than doubled (in purely numerical terms) since 1982/83 but started from such a low base that the amount is still only about A\$3 million. Given the level of inflation during this period, the high cost of providing physical security and the fact that Australia now operates over 90 diplomatic posts, this

\footnotetext{
15 These contingency plans and working groups are usefully summarised in an address by T.H. Mooney, Assistant Secretary of PSCC's Counter-Terrorist Branch, entitled 'Australia's Approach to Counter-Terrorism' and included as Appendix 11 to Annex D of the Report of the Proceedings of a $S$ tudy on the Protection of the Australian Public from Ionising Radiation (Australian Counter Disaster College, Mt. Macedon, 1983), pp.175-176.

16 The formation of the new force was in part a reversion to the situation which existed prior to the amalgamation of the Commonwealth Police and the A.C.T. Police recommended by Sir Robert Mark in April 1978. Ironically, the latest move is to help overcome a problem Sir Robert himself identified, the difficulty of adequately providing all theprotective services required in the National Capital. See Report to the Minister for Administrative Services on the Organisation of Police Resources in the Commonwealth Area and other Related Matters (Australian Government Publishing Service, Canberra, 1978).
} 
allocation seems very small. According to the Department's last Annual Report, it is in fact less than half the sum requested in its draft estimates for the 1984/85 financial year. More has been allocated for the security of Australia's diplomatic communications. ${ }^{17}$ steps are being taken to improve the security of Australian missions and residences in high risk areas but a great deal remains to be done, both in terms of upgrading premises and preparing staff and their families for the kind of situations that they may face during their service overseas. 18 It can only be hoped that these deficiencies are addressed before a terrorist attack on an Australian diplomat or diplomatic facility serves as a reminder of the need to give this matter a high priority.

17 In $1982 / 83$ A\$4.733 million was allocated for technical security and only A\$l.8 million for protective security. The following financial year the figures had risen to $A \$ 5.287$ million and $A \$ 2.9$ million respectively. The estimates for $1984 / 85$ were for $A \$ 5.738$ million for technical security and $A \$ 6.05$ million for protective security. Department of Foreign Affairs Annual Report 1983-84, p.42.

18 'Off the champagne trail', pp.167-168. In this context it is interesting to compare the report given of an address to the Foreign Affairs Womens' Association by a Department of Foreign Affairs security officer on 3 November 1983 with a similar briefing given to the (UK) Diplomatic Service Wives Association in the early .1970s by the Chief clerk of the Foreign and Commonwealth Office. It would appear that the Chief clerk was a good deal more frank in his comments and considerably less sanguine about the prospects of being able to protect diplomats and their families, than was his Australian colleague. See FAWA Newsletter 48 (December 1983), pp.1-2 and McDermott, pp. 64-65. 


\section{APPENDICES}

Appendices A-D are taken from the US State Department's publication Terrorist Incidents Involving Diplomats: A Statistical overview of International Terrorist Incidents Involving Diplomatic Personnel and Facilities from January 1968 through April 1983, published in Washington in August 1983. While some care needs to be taken with the statistics used by the state Department, as discussed earlier in this thesis, the material provided in the following lists are still considered useful.

Appendix $E$ is taken from Ian Brownlie's collection of Basic Documents in International Law, pages 213-229, and Appendices $F$ and $G$ are reproduced from M. Cherif Bassiouni's study of International Terrorism and Political Crimes, pages 321-335. In all cases these documents have been checked against the original texts of the relevant international organisations. 
Appendix A

Table 1

Terrorist Incidents Involving Foreign Diplomats

January 1968-April 1983, by Typo

\begin{tabular}{|c|c|c|c|c|c|c|c|c|c|c|c|c|c|c|c|c|c|c|}
\hline & 1968 & 1969 & 1970 & 1971 & 1972 & 1973 & 1974 & 1975 & 1976 & 1977 & 1978 & 1979 & 1980 & 1981 & 1982 & 1983 * & Totals & $\begin{array}{l}\text { Percent of } \\
\text { Grand Total }\end{array}$ \\
\hline Kidnaping & 1 & 3 & 30 & 14 & 2 & 8 & 5 & 10 & 6 & 4 & 12 & 8 & 4 & 10 & 3 & 1 & 121 & 3.7 \\
\hline $\begin{array}{l}\text { Barricadel } \\
\text { hostage }\end{array}$ & 1 & 0 & 4 & 1 & 3 & 7 & 7 & 9 & 3 & 5 & 11 & 9 & 24 & 28 & 15 & 9 & 136 & 4.1 \\
\hline Bombing & 63 & 53 & 98 & 71 & 114 & 73 & 89 & 68 & 84 & 89 & 113 & 101 & 128 & 119 & 131 & 45 & 1.439 & 43.6 \\
\hline Armed atiack & 0 & 4 & 2 & 3 & 8 & 4 & 6 & 7 & 6 & 6 & 9 & 10 & 30 & 21 & 6 & 4 & 126 & 3.8 \\
\hline Hiilacking & 0 & 0 & 0 & 0 & 0 & 0 & 0 & 0 & 0 & 0 & 0 & 2 & 3 & 2 & 7 & 1 & 15 & 0.5 \\
\hline A.ssassination b & 2 & 5 & 10 & 8 & 3 & 5 & 5 & 6 & 14 & 11 & 11 & 15 & 29 & 22 & 21 & 2 & 169 & 5.1 \\
\hline Snioing & 2 & 2 & 4 & 3 & 4 & 3 & 1 & 7 & 13 & 5 & 10 & 24 & 20 & 12 & $: 2$ & 6 & 128 & 3.9 \\
\hline Other $\mathrm{C}$ & 0 & 2 & 14 & 9 & 5 & 6 & 6 & 9 & 7 & 7 & 13 & 11 & 35 & 25 & 20 & 12 & 181 & 5.5 \\
\hline To:al & 80 & 79 & 204 & 145 & 200 & 174 & 136 & 131 & 174 & 155 & 265 & 241 & 409 & 367 & 404 & 140 & 3.304 & \\
\hline
\end{tabular}

- incluoes incidents from January tinrough April 1983.

- Includes attempted assassinations that failed.

e includes shootouts, smuggling. and so forth

This table is Unclassified.

Table 2

Locations of Terrorist Incidents Involving Foreign Diplomats,

January 1968-April 1983, by Type

\begin{tabular}{|c|c|c|c|c|c|c|c|c|c|c|}
\hline & $\begin{array}{l}\text { North } \\
\text { America }\end{array}$ & $\begin{array}{l}\text { Latin } \\
\text { America }\end{array}$ & $\begin{array}{l}\text { Western } \\
\text { Europe }\end{array}$ & $\begin{array}{l}\text { Eastern } \\
\text { Europel } \\
\text { Soviet Union }\end{array}$ & $\begin{array}{l}\text { Sub-Sanaran } \\
\text { Africa }\end{array}$ & $\begin{array}{l}\text { Middie } \\
\text { East }\end{array}$ & Asia & Pacific & Other & $\begin{array}{l}\text { Total } \\
\text { (percent) }\end{array}$ \\
\hline Kidnaping & 2 & 57 & 14 & 0 & 13 & 26 & 7 & 0 & 2 & $121(3.7)$ \\
\hline Barricade/hosiage & 9 & 58 & 41 & 2 & 1 & 21 & 3 & 0 & 1 & $136(4.1)$ \\
\hline Bombing & 192 & 327 & 529 & 15 & 20 & 234 & 83 & 14 & 15 & $1.439(43.6)$ \\
\hline Armed attack & 1 & 38 & 15 & 0 & 6 & 54 & 11 & 0 & 1 & $126(3.8)$ \\
\hline Hijacking & 0 & 2 & 0 & 3 & 3 & 4 & 3 & 0 & 0 & $15(0.5)$ \\
\hline Assassination : & 13 & 24 & 59 & 4 & 5 & 45 & 15 & 3 & 1 & $169(5.1)$ \\
\hline Sniping & 16 & 63 & 9 & 1 & 1 & 29 & 8 & 1 & 0 & $128(3.9)$ \\
\hline Other & 24 & 44 & 45 & 4 & 12 & 33 & 16 & 0 & 3 & $181(5.5)$ \\
\hline Total & $\begin{array}{l}403 \\
(12.2)\end{array}$ & $\begin{array}{l}849 \\
(25.7)\end{array}$ & $\begin{array}{l}972 \\
(29.4)\end{array}$ & $\begin{array}{l}63 \\
(1.9)\end{array}$ & $\begin{array}{l}96 \\
(2.9)\end{array}$ & $\begin{array}{l}609 \\
(18.4)\end{array}$ & $\begin{array}{l}244 \\
(7.4)\end{array}$ & $\begin{array}{l}40 \\
(9.2)\end{array}$ & $\begin{array}{l}28 \\
(0.8)\end{array}$ & 3.304 \\
\hline
\end{tabular}

- includes attempted assassinations that failed.

b includes shootouts, smuggling, and so forth

This table is Unclassified. 


\section{Appendix B}

Countries Whose Diplomats Have Been Victimized by International Terrorism

This list includes the names of each country whose foreign diplomats have been victimized by international terrorism. It is based on media coverage of these events and therefore may not cover countries that do not report incidents.

\begin{tabular}{|c|c|c|}
\hline Afghanistan & Guyana & Peru \\
\hline Albania & Haiti & Philippines \\
\hline Algeria & Honduras & Poland \\
\hline Angola & India & Portugal \\
\hline Argentina & Indonesia & Romania \\
\hline Australia & Iran & Saudi Arabia \\
\hline Austria & Iraq & Senegal \\
\hline Bangladesh & Ireland & Somalia \\
\hline Belgium & Israel & South Africa \\
\hline Bolivia & Italy & South Korea \\
\hline Brazil & Ivory Coast & South Vietnam \\
\hline Bulgaria & Jamaica & South Yemen (PDRY) \\
\hline Burma & Japan & Spain \\
\hline Canada & Jordan & Sri Lanka \\
\hline Cape Verde & Kenya & Sudan \\
\hline Chad & Kuwait & Suriname \\
\hline Chile & Laos & Sweden \\
\hline China & Lebanon & Switzerland \\
\hline Colombia & Liberia & Syria \\
\hline Congo & Libya & Tanzania \\
\hline Costa Rica & Malawi & Thailand \\
\hline Cuba & Malaysia & Tunisia \\
\hline Cyprus & Mali & Turkey \\
\hline Czechoslovakia & Mauritania & Uganda \\
\hline Denmark & Mexico & United Arab Emirates \\
\hline Dominican Republic & Mongolia & United Kingdom \\
\hline East Germany & Morocco & United States \\
\hline Ecuador & Netherlands & Uruguay \\
\hline Egypt & New Zealand & USSR \\
\hline El Salvador & Nicaragua & Vatican City \\
\hline Ethiopia & Nigeria & Venezuela \\
\hline Finland & North Korea & Vietnam \\
\hline France & North Yemen (YAR) & West Germany \\
\hline Gabon & Norway & Yugoslavia \\
\hline Ghana & Oman & Zaire \\
\hline Greece & Pakistan & Zimbabwe \\
\hline Guatemala & Panama & \\
\hline Guinea & Paraguay & Taiwan \\
\hline
\end{tabular}




\section{Appendix C}

Locations of International

Terrorist Incidents Involving

Foreign Diplomats

\begin{tabular}{|c|c|c|}
\hline Afghanistan & Grenada & Pakistan \\
\hline Albania & Guatemala & Panama \\
\hline Algeria & Guinea & Papua New Guinea \\
\hline Angola & Guyana & Paraguay \\
\hline Argentina & Haiti & Peru \\
\hline Australia & Honduras & Philippines \\
\hline Austria & Hong Kong & Poland \\
\hline Bahamas, The & Hungary & Portugal \\
\hline Bahrain & Iceland & Qatar \\
\hline Bangladesh & India & Romania \\
\hline Barbados & Indonesia & Saudi Arabia \\
\hline Belgium & Iran & Scotland \\
\hline Benin & Iraq & Sierra Leone \\
\hline Bolivia & Ireland & Singapore \\
\hline Botswana & Israel & Somalia \\
\hline Brazil & Italy & South Africa \\
\hline Bulgaria & Ivory Coast & South Korea \\
\hline Burma & Jamaica & South Yemen (PDRY) \\
\hline Burundi & Japan & Spain \\
\hline Canada & Jordan & Sri Lanka \\
\hline Central African Republic & Kampuchea & Sudan \\
\hline Chile & Kenya & Suriname \\
\hline China & Kuwait & Sweden \\
\hline Colombia & Laos & Switzerland \\
\hline Corsica & Lebanon & Syria \\
\hline Costa Rica & Lesotho & Tanzania \\
\hline Cuba & Liberia & Thailand \\
\hline Cyprus & Libya & Trinidad and Tobago \\
\hline Czechoslovakia & Luxembourg & Tunisia \\
\hline Denmark & Malaysia & Turkey \\
\hline Djibouti & Malta & Uganda \\
\hline Dominican Republic & Martinique & United Arab Emirates \\
\hline East Germany & Mexico & United Kingdom \\
\hline Ecuador & Morocco & United States \\
\hline Egypt & Mozambique & Upper Volta \\
\hline El Salvador & Nepal & Uruguay \\
\hline Equatorial Guinea & Netherlands & USSR \\
\hline Ethiopia & New Zealand & Vatican City \\
\hline Finland & Nicaragua & Venezuela \\
\hline France & Nigeria & West Germany \\
\hline Gabon & North Yemen (YAR) & Yugoslavia \\
\hline Ghana & Norway & Zambia \\
\hline Greece & Oman & \\
\hline
\end{tabular}




\section{Appendix D}

Groups Allegedly Responsible

for Terrorist Incidents Involving

Foreign Diplomats, January 1968-April 1983

This list contains the names of organizations responsible either by claim or attribution for the incidents involving diplomats reflected in the statistics. Some of these events may have taken place without the approval or even the foreknowledge of the leaders of the organizations involved. Some claims of responsibility may be false, and some names may have been invented by organizations not wishing to link their own names with particular actions or by criminal or psychotic individuals who acted alone. In other cases organizations may have claimed credit for (or been blamed for) actions they did not commit.

Group

Acilciler (Urgent Ones, part of TPLP-F)

Action Directe

Alacran (Scorpion)

Al Fatah

Al Jihad al Islami

Al Saiqa (Syrian controlled)

Ananda Marg

Anti-Imperialist Fighters for a Free Palestine

April 19 Movement ( $M-19)$

Arab Communist Organization

Armed Forces of National Liberation (FALN)

Armed Revolutionary Party of the People

Armenian Secret Army for the Liberation of

Armenia (ASALA)

Army of National Liberation (ELN)

ASEAN Moslem Liberation Front

Bandera Roja

Basque Fatherland and Liberty (ETA)

Bazargan Brigades

Black Crescent

Black December Movement

Black June Organization

Black September Organization (associated

with Al Fatah)

Charles Martel Group

Condor

Croatian Liberation Movement (emigres)

Democratic Front for the Liberation of

Palestine (DFLP)

Dominican Popular Movement

Eagles of the Palestinian Revolution 
Group

El Condor

El Poder Cubano

Eritrean Liberation Forces

Eylem Birligi Faction of TPLP-F

Farabundo Marti Popular Liberation Forces

(FPL)

Farug

February 28 Popular Leagues

Front for Liberation of Lebanon From Foreigners

Greek Anti-Dictatorial Youth

Greek Armed Group for Support of

Northern Ireland

Guerrilla Army of the Poor (EGP)

Hammer (and) Sickle Group

Holger Meins Kommando (RAF subgroup)

Honduran Revolutionary Union (URP)

Honduran Socialist Party (PASO)

International Solidarity Command for Free

Papua Movement

Invisible Ones

Iraqi Liberation Army-General Command

January 12 Liberation Movement

January 31 Popular Front

Japanese Red Army (JRA)

Jewish Defense League (Wrath of God)

June 2 Movement (2JM)

Justice Commandos for the Armenian Genocide

(JCAG)

Kurdish Democratic Party

Latin American Anti-Communist Army

Lebanese Armed Revolutionary Brigades

Lebanese Armed Revolutionary Faction (LARF)

Lorenza Zelaya

Mano Argentine National Organization Movement

Maruseido

Marxist-Leninist Armed Propaganda Unit

(MLAPU, part of TPLP-F)

May 15 Organization

Montoneros

Moro National Liberation Front

Mojahedin

Movement of the Revolutionary Left (MIR)

Muslim Brotherhood

National Liberation Alliance (ALN) 
Group

National Front for the Liberation of Congo

(FLNC)

National Democratic Popular Front

New Armenian Resistance

October 1 Anti-Fascist Revolutionary Group

(GRAPO)

Peoples Revolutionary Army

Peoples Army in Zaire (APOZA)

Peoples Strugglers

Petra Kraus Group

Polisario

Popular Front for the Liberation of Palestine

(PFLP)

Popular Army Force (FAP)

Popular Forces of April 25 (FP-25)

Popular Liberation Army (EPL)

Popular Revolutionary Bloc

Popular Revolutionary Movement

Popular Revolutionary Vanguard (VPR)

Provisional Irish Republican Army (PIRA,

Provos)

Quebec Liberation Front (FLQ)

Red Army Faction (RAF)

Revolutionary Armed Forces of Colombia

(FARC)

Revolutionary People's Struggle

Revolutionary Cells (RZ)

Revolutionary Organization of the People in

Arms (ORPA)

Revolutionary Student Front (FER)

Revolutionary Youth Union (Dev Genc)

Soldiers of the Algerian Opposition Movement

Tupamaros

Turkish People's Liberation Army (TPLA)

Turkish People's Liberation Front (TPLF)

Uganda Freedom Movement

Ukrainian Nationalist Group

United Popular Action Front

United Liberation Front for New Algeria

Voice of the People (Halkin Sesi)

Workers Party of Guatemala (PGT-FAR) 
Appendix F

\section{VIENNA CONVENTION ON DIPLOMATIC RELATIONS}

The States Parties to the present Convention,

Recalling that peoples of all nations from ancient times have recognized the status of diplomatic agents,

Having in mind the purposes and principles of the Charter of the United Nations concerning the sovereign equality of States, the maintenance of international peace and security, and the promotion of friendly relations among nations,

Believing that an international convention on diplomatic intercourse, privileges and immunities would contribute to the development of friendly relations among nations, irrespective of their differing constitutional and social systems,

Realizing that the purpose of such privileges and immunities is not to benefit individuals but to ensure the efficient performance of the functions of diplomatic missions as representing States,

Affirming that the rules of customary international law should continue to govern questions not expressly regulated by the provisions of the present Convention,

Have agreed as follows:

\section{Article 1}

For the purpose of the present Convention, the following expressions shall have the meanings hereunder assigned to them:

(a) the 'head of the mission' is the person charged by the sending State with the duty of acting in that capacity;

(b) the 'members of the mission' are the head of the mission and the members of the staff of the mission;

(c) the 'members of the staff of the mission' are the members of the diplomatic staff, of the administrative and technical staff and of the service staff of the mission;

(d) the 'members of the diplomatic staff' are the members of the staff of the mission having diplomatic rank;

(e) a 'diplomatic agent' is the head of the mission or a member of the diplomatic staff of the mission;

(f) the 'members of the administrative and technical staff are the members of the staff of the mission employed in the administrative and technical service of the mission; 
$(g)$ the 'members of the service staff' are the members of the staff of the mission in the domestic service of the mission;

(b) a 'private servant' is a person who is in the domestic service of a member of the mission and who is not an employee of the sending State;

(i) the 'premises of the mission' are the buildings or parts of buildings and the land ancillary thereto, irrespective of ownership, used for the purposes of the mission including the residence of the head of the mission.

\section{Article 2}

The establishment of diplomatic relations between States, and of permanent diplomatic missions, takes place by mutual consent.

\section{Article 3}

1. The functions of a diplomatic mission consist inter alia in:

(a) representing the sending State in the receiving State;

(b) protecting in the receiving State the interests of the sending State and of its nationals, within the limits permitred by international law;

(c) negotiating with the Government of the receiving State;

(d) ascertaining by all lawful means conditions and developments in the receiving State, and reporting thereon to the Government of the sending State;

(e) promoting friendly relations between the sending State and the receiving State, and developing their economic, cultural and scientific relations.

2. Nothing in the present Convention shall be construed as preventing the performance of consular functions by a diplomatic mission.

\section{Article 4}

1. The sending State must make certain that the agrement of the receiving State has been given for the person it proposes to accredit as head of the mission to that State.

2. The receiving State is not obliged to give reasons to the sending State for a refusal of agrément. 


\section{Article 5}

1. The sending State may, after it has given due notification to the receiving States concerned, accredit a head of mission or assign any member of the diplomatic staff, as the case may be, to more than one State, unless there is express objection by any of the receiving States.

2. If the sending State accredits a head of mission to one or more other States it may establish a diplomatic mission headed by a chargé d'affaires ad interim in each State where the head of mission has not his permanent seat.

3. A head of mission or any member of the diplomatic staff of the mission may act as representative of the sending State to any international organization.

\section{Article 6}

Two or more States may accredit the same person as head of mission to another state, unless objection is offered by the receiving State.

\section{Article 7}

Subject to the provisions of Articles 5, 8, 9 and 11, the sending State may freely appoint the members of the staff of the mission. In the case of military, naval or air attachés, the receiving State may require their names to be submitted beforehand, for its approval.

\section{Article 8}

1. Members of the diplomatic staff of the mission should in principle be of the nationality of the sending State.

2. Members of the diplomatic staff of the mission may not be appointed from among persons having the nationality of the receiving State, except with the consent of that State which may be withdrawn at any time.

3. The receiving State may reserve the same right with regard to nationals of a third State who are not also nationals of the sending State.

\section{Article 9}

1. The receiving State may at any time and without having to explain its decision, notify the sending State that the head of the mission or any member of the diplomatic staff of the mission is 
persona non grata or that any other member of the staff of the mission is not acceptable. In any such case, the sending State shall, as appropriate, either recall the person concerned or terminate his functions with the mission. A person may be declared non grata or not acceptable before arriving in the territory of the receiving State.

2. If the sending State refuses or fails within a reasonable period to carry out its obligations under paragraph 1 of this Article, the receiving State may refuse to recognize the person concerned as a member of the mission.

\section{Article 10}

1. The Ministry for Foreign Affairs of the receiving State, or such other ministry as may be agreed, shall be notified of:

(a) the appointment of members of the mission, their arrival and their final departure or the termination of their functions with the mission;

(b) the arrival and final departure of a person belonging to the family of a member of the mission and, where appropriate, the fact that a person becomes or ceases to be a member of the family of a member of the mission.

(c) the arrival and final departure of private servants in the employ of persons referred to in sub-paragraph $(a)$ of this paragraph and, where appropriate, the fact that they are leaving the employ of such persons;

(d) the engagement and discharge of persons resident in the receiving State as members of the mission or private servants entitled to privileges and immunities.

2. Where possible, prior notification of arrival and final departure shall also be given.

\section{Article 11}

1. In the absence of specific agreement as to the size of the mission, the receiving State may require that the size of a mission be kept within limits considered by it to be reasonable and normal, having regard to circumstances and conditions in the receiving State and to the needs of the particular mission.

2. The receiving State may equally, within similar bounds and on a non-discriminatory basis, refuse to accept officials of a particular category. 


\section{Article 12}

The sending State may not, without the prior express consent of the receiving State, establish offices forming part of the mission in localities other than those in which the mission itself is established.

\section{Article 13}

1. The head of the mission is considered as having taken up his functions in the receiving State either when he has presented his credentials or when he has notified his arrival and a true copy of his credentials has been presented to the Ministry for Foreign Affairs of the receiving State, or such other ministry as may be agreed, in accordance with the practice prevailing in the receiving State which shall be applied in a uniform manner.

2. The order of presentation of credentials or of a true copy thereof will be determined by the date and time of the arrival of the head of the mission.

\section{Article 14}

1. Heads of mission are divided into three classes, namely:

(a) that of ambassadors or nuncios accredited to Heads of State, and other heads of mission of equivalent rank;

(b) that of envoys, ministers and internuncios accredited to Heads of State;

(c) that of charge d'affaires accredited to Ministers of Foreign Affairs.

2. Except as concerns precedence and etiquette, there shall be no differentiation between heads of mission by reason of their class.

\section{Article 15}

The class to which the heads of their missions are to be assigned shall be agreed between States.

\section{Article 16}

1. Heads of mission shall take precedence in their respective classes in the order of the date and time of taking up their functions in accordance with Article 13.

2. Alterations in the credentials of a head of mission not involving any change of class shall not affect his precedence. 
3. This article is without prejudice to any practice accepted by the receiving State regarding the precedence of the representative of the Holy See.

\section{Article 17}

The precedence of the members of the diplomatic staff of the mission shall be notified by the head of the mission to the Ministry for Foreign Affairs or such other ministry as may be agreed.

\section{Article 18}

The procedure to be observed in each State for the reception of heads of mission shall be uniform in respect of each class.

\section{Article 19}

1. If the post of head of the mission is vacant, or if the head of the mission is unable to perform his function, a chargé d'affaires ad interim shall act provisionally as head of the mission. The name of the charge d'affaires ad interim shall be notified, either by the head of the mission or, in case he is unable to do so, by the Ministry for Foreign Affairs of the sending State to the Ministry for Foreign Affairs of the receiving State or such other ministry as may be agreed.

2. In cases where no member of the diplomatic staff of the mission is present in the receiving State, a member of the administrative and technical staff may, with the consent of the receiving State, be designated by the sending State to be in charge of the current administrative affairs of the mission.

\section{Article 20}

The mission and its head shall have the right to use the flag and emblem of the State on the premises of the mission, including the residence of the head of the mission, and on his means of transport.

\section{Article 21}

1. The receiving State shall either facilitate the acquisition on its territory, in accordance with its laws, by the sending State of premises necessary for its mission or assist the larter in obtaining accommodation in some other way.

2. It shall also, where necessary, assist missions in obtaining suitable accommodation for their members. 


\section{Article 22}

1. The premises of the mission shall be inviolable. The agents of the receiving State may not enter them, except with the consent of the head of the mission.

2. The receiving State is under a special dury to take all appropriate steps to protect the premises of the mission against any intrusion or damage and to prevent any disturbance of the peace of the mission or impairment of its dignity.

3. The premises of the mission, their furnishings and other property thereon and the means of transport of the mission shall be immune from search, requisition, attachment or execution.

\section{Article 23}

1. The sending State and the head of the mission shall be exempt from all national, regional or municipal dues and taxes in respect of the premises of the mission, whether owned or leased, other than such as represent payment for specific services rendered.

2. The exemption from taxation referred to in this Article shall not apply to such dues and taxes payable under the law of the receiving State by persons contracting with the sending State or the head of the mission.

\section{Article 24}

The archives and documents of the mission shall be inviolable at any time and wherever they may be.

\section{Article 25}

The receiving State shall accord full facilities for the performance of the functions of the mission.

\section{Article 26}

Subject to its laws and regulations concerning zones entry into which is prohibited or regulated for reasons of national security, the receiving State shall ensure to all members of the mission freedom of movement and travel in its territory.

\section{Article 27}

1. The receiving State shall permit and protect free communication on 
the part of the mission for all official purposes. In communicating with the government and the other missions and consulates of the sending Stare, wherever situated, the mission may employ all appropriate means, including diplomatic couriers and messages in code or cipher. However, the mission may install and use a wireless transmirter only with the consent of the receiving State.

2. The official correspondence of the mission shall be inviolable. Official correspondence means all correspondence relating to the mission and its functions.

3. The diplomatic bag shall not be opened or detained.

4. The packages constituting the diplomatic bag must bear visible external marks of their character and may contain only diplomatic documents or articles intended for official use.

5. The diplomatic courier, who shall be provided with an official document indicating his status and the number of packages constituting the diplomatic bag, shall be protected by the receiving State in the performance of his functions. He shall enjoy personal inviolability and shall not be liable to any form of arrest or detention.

6. The sending State or the mission may designate diplomatic couriers ad hoc. In such cases the provisions of paragraph 5 of this Article shall also apply, except that the immunities therein mentioned shall cease to apply when such a courier has delivered to the consignee the diplomatic bag in his charge.

7. A diplomatic bag may be entrusted to the captain of a commercial aircraft scheduled to land at an authorized port of entry. He shall be provided with an official document indicating the number of packages constituting the bag but he shall not be considered to be a diplomatic courier. The mission may send one of its members to take possession of the diplomatic bag directly and freely from the captain of the aircraft.

\section{Article 28}

The fees and charges levied by the mission in the course of official duties shall be exempt from all dues and taxes.

\section{Article 29}

The person of a diplomatic agent shall be inviolable. He shall not be liable to any form of arrest or detention. The receiving State shall treat 
him with due respect and shall take all appropriate steps to prevent any attack on his person, freedom, or dignity.

\section{Article 30}

1. The private residence of a diplomatic agent shall enjoy the same inviolability and protection as the premises of the mission.

2. His papers, correspondence, and, except as provided in paragraph 3 of Article 31, his property, shall likewise enjoy inviolability.

\section{Article 31}

1. A diplomatic agent shall enjoy immunity from the criminal jurisdiction of the receiving State. He shall also enjoy immunity from its civil and administrative jurisdiction, except in the case of:

(a) a real action relating to private immovable property situated in the territory of the receiving State, unless he holds it on behalf of the sending State for the purposes of the mission;

(b) an action relating to succession in which the diplomatic agent is involved as executor, administrator, heir or legatee as a private person and not on behalf of the sending State;

(c) an action relating to any professional or commercial activity exercised by the diplomatic agent in the receiving State outside his official functions.

2. A diplomatic agent is not obliged to give evidence as a witness.

3. No measures of execution may be taken in respect of a diplomatic agent except in the cases coming under sub-paragraphs $(a),(b)$ and $(c)$ of paragraph 1 of this Article, and provided that the measures concerned can be taken without infringing the inviolability of his person or of his residence.

4. The immunity of a diplomatic agent from the jurisdiction of the receiving State does not exempt him from the jurisdiction of the sending State.

\section{Article 32}

1. The immunity from jurisdiction of diplomatic agents and of persons enjoying immunity under Article 37 may be waived by the sending State.

2. Waiver must always be express.

3. The initiation of proceedings by a diplomatic agent or by a person enjoying immunity from jurisdiction under Article 37 shall preclude 
him from invoking immunity from jurisdiction in respect of any counterclaim directly connected with the principal claim.

4. Waiver of immunity from jurisdiction in respect of civil or administrative proceedings shall not be held to imply waiver of immunity in respect of the execution of the judgment, for which a separate waiver shall be necessary.

\section{Article 33}

1. Subject to the provisions of paragraph 3 of this Article, a diplomatic agent shall with respect to services rendered for the sending State be exempt from social security provisions which may be in force in the receiving State.

2. The exemption provided for in paragraph 1 of this Article shall also apply to private servants who are in the sole employ of a diplomatic agent, on conditions:

(a) that they are not nationals of or permanently resident in the receiving State; and

(b) that they are covered by the social security provisions which may be in force in the sending State or a third State.

3. A diplomatic agent who employs persons to whom the exemption provided for in paragraph 2 of this Article does not apply shall observe the obligations which the social security provisions of the receiving State impose upon employers.

4. The exemption provided for in paragraphs 1 and 2 of this Article shall not preclude voluntary participation in the social security system of the receiving State provided that such participation is permitted by that State.

5. The provisions of this Article shall not affect bilateral or multilateral agreements concerning social security concluded previously and shall not prevent the conclusion of such agreements in the future.

Article 34

A diplomatic agent shall be exempt from all dues and taxes, personal or real, national, regional or municipal, except:

(a) indirect taxes of a kind which are normally incorporated in the price of goods or services;

(b) dues and taxes on private immovable property situated in the 
territory of the receiving State, unless he holds it on behalf of the sending State for the purposes of the mission;

(c) estate, succession or inheritance duties levied by the receiving State, subject to the provisions of paragraph 4 of Article 39.

(d) dues and taxes on private income having its source in the receiving State and capital taxes on investments made in commercial undertakings in the receiving State;

(e) charges levied for specific services rendered;

(f) registration, court or record fees, mortgage dues and stamp duty, with respect to immovable property, subject to the provisions of Article 23.

Article 35

The receiving State shall exempt diplomatic agents from all personal services, from all public service of any kind whatsoever, and from military obligations such as those connected with requisitioning, military contributions and billeting.

\section{Article 36}

1. The receiving State shall, in accordance with such law's and regulations as it may adopt, permit entry of and grant exemption from all customs duties, taxes, and related charges other than charges for storage, cartage and similar services, on:

(a) articles for official use of the mission;

(b) articles for the personal use of a diplomatic agent or members of his family forming part of his household, including articles intended for his establishment.

2. The personal baggage of a diplomatic agent shall be exempt from inspection, unless there are serious grounds for presuming that it contains articles not covered by the exemptions mentioned in paragraph 1 of this Article, or articles the import or export of which is prohibited by the law or controlled by the quarantine regulations of the receiving State. Such inspection shall be conducted only in the presence of the diplomatic agent or of his authorized representative.

\section{Article 37}

1. The members of the family of a diplomatic agent forming part of his household shall, if they are not nationals of the receiving State, enjoy the privileges and immunities specified in Articles 29 to 36. 
2. Members of the administrative and technical staff of the mission, together with members of their families forming part of their respective households, shall, if they are not nationals of or permanently resident in the receiving State, enjoy the privileges and immunities specified in Articles 29 to 35, except that the immunity from civil and administrative jurisdiction of the receiving State specifed in paragraph 1 of Article 31 shall not extend to acts performed outside the course of their duties. They shall also enjoy the privileges specified in Article 36, paragraph 1, in respect of articles imported at the time of first installation.

3. Members of the service staff of the mission who are not nationals of or permanently resident in the receiving State shall enjoy immunity in respect of acts performed in the course of their duties, exemption from dues and taxes on the emoluments they receive by reason of their employment and the exemption contained in Article 33.

4. Private servants of members of the mission shall, if they are not nationals of or permanently resident in the receiving State, be exempt from dues and taxes on the emoluments they receive by reason of their employment. In other respects, they may enjoy privileges and immunities only to the extent admitred by the receiving State. However, the receiving State must exercise its jurisdiction over those persons in such a manner as not to interfere unduly with the performance of the functions of the mission.

\section{Article 38}

1. Except in so far as additional privileges and immunities may be granted by the receiving State, a diplomatic agent who is a national of or permanently resident in that State shall enjoy only immunity from jurisdiction, and inviolability, in respect of official acts performed in the exercise of his functions.

2. Other members of the staff of the mission and private servant: who are nationals of or permanently resident in the receiving Statc shall enjoy privileges and immunities only to the extent admitted b: the receiving State. However, the receiving State must exercise itjurisdiction over those persons in such a manner as not to interfer، unduly with the performance of the functions of the mission.

\section{Article 39}

1. Every person entitled to privileges and immunities shall enjo: 
them from the moment he enters the territory of the receiving State on proceeding to take up his post or, if already in its territory, from the moment when his appointment is notified to the Ministry for Foreign Affairs or such other ministry as may be agreed.

2. When the functions of a person enjoying privileges and immunities have come to an end, such privileges and immunities shall normally cease at the moment when he leaves the country, or on expiry of a reasonable period in which to do so, but shall subsist until that time, even in case of armed conflict. However, with respect to acts performed by such a person in the exercise of his functions as a member of the mission, immunity shall continue to subsist.

3. In case of the death of a member of the mission, the members of his family shall continue to enjoy the privileges and immunities to which they are entitled until the expiry of a reasonable period in which to leave the country.

4. In the event of the death of a member of the mission not a national of or permanently residing in the receiving State or a member of his family forming part of his household, the receiving State shall permit the withdrawal of the movable property of the deceased, with the exception of any property acquired in the country the export of which was prohibited at the time of his death. Estate, succession and inheritance duties shall not be levied on movable property the presence of which in the receiving State was due solely to the presence there of the deceased as a member of the mission or as a member of the family of a member of the mission.

\section{Article 40}

1. If a diplomatic agent passes through or is in the territory of a third State, which has granted him a passport visa if such visa was necessary, while proceeding to take up or to return to his post, or when returning to his own country, the third State shall accord him inviolability and such other immunities as may be required to ensure his transit or return. The same shall apply in the case of any members of his family enjoying privileges or immunities who are accompanying the diplomatic agent or travelling separately to join him or to return to their country.

2. In circumstances similar to those specified in paragraph 1 of this Article, third States shall not hinder the passage of members of the 
administrative and technical or service staff of a mission, and of members of their families, through their territories.

3. Third States shall accord to official correspondence and other official communications in transit, including messages in code or cipher, the same freedom and protection as is accorded by the receiving State. They shall accord to diplomatic couriers, who have been granted a passport visa if such visa was necessary, and diplomatic bags in transit the same inviolability and protection as the receiving State is bound to accord.

4. The obligations of third States under paragraphs 1,2 and 3 of this Article shall also apply to the persons mentioned respectively in those paragraphs, and to official communications and diplomatic bags, whose presence in the territory of the third State is due to force majeure.

\section{Article 41}

1. Without prejudice to their privileges and immunities, it is the dury of all persons enjoying such privileges and immunities to respect the laws and regulations of the receiving State. They also have a duty not to interfere in the internal affairs of that State.

2. All official business with the receiving State entrusted to the mission by the sending State shall be conducted with or through the Ministry for Foreign Affairs of the receiving State or such other ministry as may be agreed.

3. The premises of the mission must not be used in any manner incompatible with the functions of the mission as laid down in the present Convention or by other rules of general international law or by any special agreements in force between the sending Stare and the receiving State.

\section{Article 42}

A diplomatic agent shall not in the receiving State practise for personal profit any professional or commercial activity.

\section{Article 43}

The function of a diplomatic agent comes to an end, inter alia:

(a) on notification by the sending State to the receiving State that the function of the diplomatic agent has come to an end; 
(b) on notification by the receiving State to the sending State that, in accordance with paragraph 2 of Article 9, it refuses to recognize the diplomatic agent as a member of the mission.

\section{Article 44}

The receiving State must, even in case of armed conflict, grant facilities in order to enable persons enjoying privileges and immunities, other than nationals of the receiving State, and members of the families of such persons irrespective of their nationality, to leave at the earliest possible moment. It must, in particular, in case of need, place at their disposal the necessary means of transport for themselves and their property.

\section{Article 45}

If diplomatic relations are broken off between two States, or if a mission is permanently or temporarily recalled:

(a) the receiving State must, even in the case of armed conflict, respect and protect the premises of the mission, together with its property and archives;

(b) the sending State may entrust the custody of the premises of the mission, together with its property and archives, to a third State acceptable to the receiving State;

(c) the sending State may entrust the protection of its interests and those of its nationals to a third State acceptable to the receiving State.

\section{Article 46}

A sending State may with the prior consent of a receiving State, and at the request of a third State not represented in the receiving State, undertake the temporary protection of the interests of the third State and of its nationals.

\section{Article 47}

1. In the application of the provisions of the present Convention, the receiving State shall not discriminate between States.

2. However, discrimination shall not be regarded as taking place:

(a) where the receiving State applies any of the provisions of the present Convention restrictively because of a restrictive application of that provision to its mission in the sending State; 
(b) where by custom or agreement States extend to each other more favourable treatment than is required by the provisions of the present Convention.

\section{Article 48}

The present Convention shall be open for all States Members of the United Nations or of any of the specialized agencies or Parties to the Statute of the International Court of Justice, and by any other State invited by the General Assembly of the United Nations to become a Party to the Convention, as follows: until 31 October 1961 at the Federal Ministry of Foreign Affairs of Austria and subsequently, until 31 March 1962, at the United Nations Headquarters in New York.

\section{Article 49}

The present Convention is subject to ratification. The instruments of ratification shall be deposited with the Secretary-General of the United Nations.

\section{Article 50}

The present Convention shall remain open for accession by any State belonging to any of the four categories mentioned in Article 48. The instruments of accession shall be deposited with the SecretaryGeneral of the United Nations.

\section{Article 51}

1. The present Convention shall enter into force on the thirtieth day following the date of deposit of the twenty-second instrument of ratification or accession with the Secretary-General of the United Nations.

2. For each State ratifying or acceding to the Convention after the deposit of the twenty-second instrument of ratification or accession, the Convention shall enter into force on the thirtieth day after deposit by such State of its instrument of ratification or accession.

\section{Article 52}

The Secretary-General of the United Nations shall inform all States belonging to any of the four categories mentioned in Article 48:

(a) of signatures to the present Convention and of the deposit of 
instruments of ratification or accession, in accordance with Arricles 48, 49 and 50.

(b) of the date on which the present Convention will enter into force, in accordance with Article 51.

\section{Article 53}

The original of the present Convention, of which the Chinese. English, French, Russian and Spanish texts are equally authentic, shall be deposited with the Secretary-General of the United Nations, who shall send certified copies thereof to all States belonging to any of the four categories mentioned in Article 48.

IN W'ITNESS WHEREOF the undersigned Plenipotentiaries, being duly authorized thereto by their respective Governments, have signed the present Convention.

DONE AT VIENNA, this eighteenth day of April one thousand nine hundred and sixty-one. 


\section{Appendix F}

Convention to Prevent and Punish the Acts of Terrorism Taking the Form of Crimes Against Persons and Related Extortion That Are of International Significance, Signed at Washington February 2, 1971

\section{WHEREAS:}

The Defense of FReEDom and justice and respect for the fundamental rights of the individual that are recognized by the American Declaration of the Rights and Duties of Man and the Universal Declaration of Human Rights are primary duties of States;

The General Assembly of the Organization, in resolution 4, of June 30,1970 , strongly condemned acts of terrorism, especially the kidnapping of persons and extortion in connection with that crime, which it declared to be serious common crimes;

Criminal acts against persons entitled to special protection under international law are occurring frequently, and those acts are of international significance because of the consequences that may flow from them for relations among States;

It is advisable to adopt general standards that will progressively develop international law as regards cooperation in the prevention and punishment of such acts; and

In the application of those standards the institution of asylum should be maintained and, likewise the principle of nonintervention should not be impaired,

THE MEMBER STATES OF THE ORGANIZATION OF AMERICAN STATES HAVE AGREED UPON THE FOL LOWING ARTICLES: 


\section{Article 1}

The Contracting States undertake to cooperate among themselves by taking all the measures that they may consider effective, under their own laws and especially those established in this convention, to prevent and punish acts of terrorism, especially kidnapping, murder, and other assaults against the life or physical integrity of those persons to whom the State has the duty according to international law to give special protection, as well as extortion in connection with those crimes.

\section{Article 2}

For the purposes of this Convention, kidnapping, murder and other assaults against the life or personal integrity of those persons to whom the State has the duty to give special protection according to international law, as well as extortion in connection with those crimes, shall be considered common crimes of international significance, regardless of motive.

\section{Article 3}

Persons who have been charged or convicted for any of the crimes referred to in Article 2 of this Convention shall be subject to extradition under the provisions of the extradition treaties in force between the parties or, in the case of States that do not make extradition dependent on the existence of a treaty, in accordance with their own laws.

In any case, it is the exclusive responsibility of the State under whose jurisdiction or protection such persons are located to determine the nature of the acts and decide whether the standards of this Convention are applicable.

\section{Article 4}

Any person deprived of his freedom through the application of this Convention shall enjoy the legal guarantees of due process.

\section{Article 5}

When extradition requested for one of the crimes specified in Article 2 is not in order because the person sought is a national of 
the requested State, or because of some other legal or constitutional impediment, that State is obliged to submit the case to its competent authorities for prosecution, as if the act had been committed in its territory. The decision of these authorities shall be communicated to the State that requested extradition. In such proceedings, the obligation established in Article 4 shall be respected.

\section{Article 6}

None of the provisions of this Convention shall be interpreted so as to impair the right of asylum.

\section{Article 7}

The Contracting States undertake to include the crimes referred to in Article 2 of this Convention among the punishable acts giving rise to extradition in any treaty on the subject to which they agree among themselves in the future. The Contracting States that do not subject extradition to the existence of a treaty with the requesting State shall consider the crimes referred to in Article 2 of this Convention as crimes giving rise to extradition, according to the conditions established by the laws of the requested State.

\section{Article 8}

To cooperate in prevention and punishing the crimes contemplated in Article 2 of this Convention, the Contracting States accept the following obligations:

(a) To take all measures within their power, and in conformity with their own laws, to prevent and impede the preparation in their respective territories of the crimes mentioned in Article 2 that are to be carried out in the territory of another Contracting State.

(b) To exchange information and consider effective administrative measures for the purpose of protecting the persons to whom Article 2 of this Convention refers.

(c) To guarantee to every person deprived of his freedom through the application of this Convention every right to defend himself. 
(d) To endeavour to have the criminal acts contemplated in this Convention included in their penal laws, if not already so included.

(e) To comply most expeditiously with the requests for extradition concerning the criminal acts contemplated in this Convention.

\section{Article 9}

This Convention shall remain open for signature by the member States of the Organization of American States, as well as by any other State that is a Member of the United Nations or any of its specialized agencies, or any State that is a party to the Statute of the International Court of Justice, or any other State that may be invited by the General Assembly of the Organization of American States to sign it.

\section{Article 10}

This Convention shall be ratified by the signatory States in accordance with their respective constitutional procedures.

\section{Article 11}

The original instrument of this Convention, the English, French, Portuguese, and Spanish texts of which are equally authentic, shall be deposited in the General Secretarist of the Organization of American States, which shall send certified copies to the signatory Governments for purposes of ratification. The instruments of ratification shall be deposited in the General Secretariat of the Organization of American States, which shall notify the signatory Governments of such deposit.

\section{Article 12}

This Convention shall enter into force among the States that ratify it when they deposit their respective instruments of ratification. 


\section{Article 13}

This Convention shall remain in force indefinitely, but any of the Contracting States may denounce it. The denunciation shall be transmitted to the General Secretariat of the Organization of American States, which shall notify the other Contracting States thereof. One year following the denunciation, the Convention shall cease to be in force for the denouncing State, but shall continue to be in force for the other Contracting States. 
Appendix G

\title{
RESOLUTION ADOPTED BY THE GENERAL ASSEMBLY
}

\author{
Convention on the Prevention and Punishment of Crimes \\ Against Internationally Protected Persons, Including \\ Diplomatic Agents
}

The General Assembly,

Considering that the codification and progressive development of international law contributes to the implementation of the purposes and principles set forth in Articles 1 and 2 of the Charter of the United Nations,

Recalling that in response to the request made in General Assembly resolution 2780 (XXVI) of December 3, 1971, the International Law Commission, at its twenty-fourth session, studied the question of the protection and inviolability of diplomatic agents and other persons entitled to special protection under international law and prepared draft articles ${ }^{1}$ on the prevention and punishment of crimes against such persons,

Having considered the draft articles and also the comments and observations thereon submitted by States, specialized agencies and other intergovernmental organizations ${ }^{2}$ in response to the invitation extended by the General Assembly in its resolution 2926 (XXVII) of November 28, 1972.

Convinced of the importance of securing international agreement on appropriate and effective measures for the prevention and punishment of crimes against diplomatic agents and other internationally protected persons in view of the serious threat to the 
maintenance and promotion of friendly relations and cooperation among States created by the commission of such crimes,

Having elaborated for that purpose the provisions contained in the Convention annexed hereto,

1. Adopts the Convention on the Prevention and Punishment of Crimes against Internationally Protected Persons, including Diplomatic Agents, annexed to the present resolution;

2. Reemphasizes the great importance of the rules of internanational law concerning the inviolability of and special protection to be afforded to internationally protected persons and the obligations of States in relation thereto;

3. Considers that the annexed Convention will enable States to carry out their obligations more effectively;

4. Recognizes also that the provisions of the annexed Convention could not in any way prejudice the exercise of the legitimate right to self-determination and independence, in accordance with the purposes and principles of the Charter of the United Nations and the Declaration on Principles of International Law concerning Friendly Relations and Cooperation among States in accordance with the Charter of the United Nations, by peoples struggling against colonialism, alien domination, foreign occupation, racial discrimination and apartheid;

5. Invites States to become parties to the annexed Convention;

6. Decides that the present resolution, whose provisions are related to the annexed Convention, shall always be published together with it.

2202 plenary meeting

14 December 1973

The States Parties to this Convention,

Having in mind the purposes and principles of the Charter of the United Nations concerning the maintenance of international peace and the promotion of friendly relations and cooperation among States,

Considering that crimes against diplomatic agents and other internationally protected persons jeopardizing the safety of these 
persons create a serious threat to the maintenance of normal international relations which are necessary for cooperation among States,

Believing that the commission of such crimes is a matter of grave concern to the international community,

Convinced that there is an urgent need to adopt appropriate and effective measures for the prevention and punishment of such crimes,

Have agreed as follows:

\section{Article 1}

For the purposes of this Convention:

1. "internationally protected person" means:

(a) a Head of State, including any member of a collegial body performing the functions of a Head of State under the constitution of the State concerned, a Head of Government or a Minister for Foreign Affairs, whenever any such person is in a foreign State, as well as members of his family who accompany him;

(b) any representative or official of a State or any official or other agent of an international organization of an intergovernmental character who, at the time when and in the place where a crime against him, his official premises, his private accommodation or his means of transport is committed, is entitled pursuant to international law to special protection from any attack on his person, freedom or dignity, as well as members of his family forming part of his household;

2. "alleged offender" means a person as to whom there is sufficient evidence to determine prima facie that he has committed or participated in one or more of the crimes set forth in article 2.

\section{Article 2}

1. The intentional commission of:

(a) a murder, kidnapping or other attack upon the person or liberty of an internationally protected person; 
(b) a violent attack upon the official premises, the private accommodation or the means of transport of an internationally protected person likely to endanger his person or liberty;

(c) a threat to commit any such attack;

(d) an attempt to commit any such attack; and

(e) an act constituting participation as an accomplice in any such attack shall be made by each State Party a crime under its internal law.

2. Each State Party shall make these crimes punishable by appropriate penalties which take into acount their grave nature.

3. Paragraphs 1 and 2 of this article in no way derogate from the obligations of States Parties under international law to take all appropriate measures to prevent other attacks on the person, freedom or dignity of an internationally protected person.

\section{Article 3}

1. Each State Party shall take such measures as may be necessary to establish its jurisdiction over the crimes set forth in article 2 in the following cases:

(a) when the crime is committed in the territory of that State or on board a ship or aircraft registered in that State;

(b) when the alleged offender is a national of that State;

(c) when the crime is committed against an internationally protected person as defined in article 1 who enjoys his status as such by virtue of functions which he exercises on behalf of that State.

2. Each State Party shall likewise take such measures as may be necessary to establish its jurisdiction over these crimes in cases where the alleged offender is present in its territory and it does not extradite him pursuant to article 8 to any of the States mentioned in paragraph 1 of this article.

3. This Convention does not exclude any criminal jurisdiction exercised in accordance with internal law. 
Article 4

States Parties shall cooperate in the prevention of the crimes set forth in article 2 , particularly by:

(a) taking all practicable measures to prevent preparations in their respective territories for the commission of those crimes within or outside their territories;

(b) exchanging information and coordinating the taking of administrative and other measures as appropriate to prevent the commission of those crimes.

\section{Article 5}

1. The State Party in which any of the crimes set forth in article 2 has been committed shall, if it has reason to believe that an alleged offender has fled from its territory, communicate to all other States concerned, directly or through the Secretary-General of the United Nations, all the pertinent facts regarding the crime committed and all available information regarding the identity of the alleged offender.

2. Whenever any of the crimes set forth in article 2 has been committed against an internationally protected person, any State Party which has information concernining the victim and the circumstances of the crime shall endeavour to transmit it, under the conditions provided for in its internal law, fully and promptly to the State Party on whose behalf he was exercising his functions.

\section{Article 6}

1. Upon being satisfied that the circumstances so warrant, the State Party in whose territory the alleged offender is present shall take the appropriate measures under its internal law so as to ensure his presence for the purpose of prosecution or extradition. Such measures shall be notified without delay directly or through the Secretary-General of the United Nations to:

(a) the State where the crime was committed;

(b) the State or States of which the alleged offender is a na- 
tional or, if he is a stateless person, in whose territory he permanently resides;

(c) the State or States of which the internationally protected person concerned is a national or on whose behalf he was exercising his functions;

(d) all other States concerned; and

(e) the international organization of which the internationally protected person concerned is an official or an agent.

2. Any person regarding whom the measures referred to in paragraph $\mathrm{I}$ of this article are being taken shall be entitled:

(a) to communicate without delay with the nearest appropriate representative of the State of which he is a national or which is otherwise entitled to protect his rights or, if he is a stateless person, which he requests and which is willing to protect his rights; and

(b) to be visited by a representative of that State.

\section{Article 7}

The State Party in whose territory the alleged offender is present shall, if it does not extradite him, submit, without exception whatsoever and without undue delay, the case to its competent authorities for the purpose of prosecution, through proceedings in accordance with the laws of the State.

\section{Article 8}

1. To the extent that the crimes set forth in article 2 are not listed as extraditable offenses in any extradition treaty existing between States Parties, they shall be deemed to be included as such therein. States Parties undertake to include those crimes as extraditable offenses in every future extradition treaty to be concluded between them.

2. If a State Party which makes extradition conditional on the existence of a treaty receives a request for extradition from another State Party with which it has no extradition treaty, it may, if it decided to extradite, consider this Convention as the legal basis for extradition in respect of those crimes. Ex- 
tradition shall be subject to the procedural provisions and the other conditions of the law of the requested State.

3. State Parties which do not make extradition conditional on the existence of a treaty shall recognize those crimes as extraditionable offenses between themselves subject to the procedural provisions and the other conditions of the law of the requested State.

4. Each of the crimes shall be treated, for the purpose of extradition between States Parties, as if it had been committed not only in the place in which it occurred but also in the territories of the States required to establish their jurisdiction in accordance with paragraph 1 of article 3.

Article 9

Any person regarding whom proceedings are being carried out in connection with any of the crimes set forth in article 2 shall be guaranteed fair treatment at all stages of the proceedings.

\section{Article 10}

1. State Parties shall afford one another the greatest measure of assistance in connection with criminal proceedings brought in respect of the crimes set forth in article 2, including the supply of all evidence at their disposal necessary for the proceedings.

2. The provisions of paragraph $I$ of this article shall not affect obligations concerning mutual judicial assistance embodied in any other treaty.

\section{Article 11}

The State Party where an alleged offender is prosecuted shall communicate the final outcome of the proceedings to the SecretaryGeneral of the United Nations, who shall transmit the information to the other States Parties.

\section{Article 12}

The provisions of this Convention shall not affect the application of the Treaties on Asylum, in force at the date of the adoption 
of this Convention, as between the States which are parties to those Treaties; but a State Party to this Convention may not invoke those Treaties with respect to another State Party to this Convention which is not a party to those Treaties.

\section{Article 13}

1. Any dispute between two or more States Parties concerning the interpretation or application of this Convention which is not settled by negotiation shall, at the request of one of them, be submitted to arbitration. If within six months from the date of the request for arbitration the parties are unable to agree on the organization of the arbitration, any one of those parties may refer the dispute to the International Court of Justice by request in conformity with the Statute of the Court.

2. Each State Party may at the time of signature or ratification of this Convention or accession thereto declare that it does not consider itself bound by paragraph 1 of this article. The other States Parties shall not be bound by paragraph 1 of this article with respect to any State Party which has made such a reservation.

3. Any State Party which has made a reservation in accordance with paragraph 2 of this article may at any time withdraw that reservation by notification to the Secretary-General of the United Nations.

\section{Article 14}

This Convention shall be open for signature by all States, until December 31, 1974 at United Nations Headquarters in New York.

\section{Article 15}

This Convention is subject to ratification. The instruments of ratification shall be deposited with the Secretary-General of the United Nations. 


\section{Article 16}

This Convention shall remain open for accession by any State. The instruments of accession shall be deposited with the SecretaryGeneral of the United Nations.

\section{Article 17}

1. This Convention shall enter into force on the thirtieth day following the date of deposit of the twenty-second instrument of ratification or accession with the Secretary-General of the United Nations.

2. For each State ratifying or acceding to the Convention after the deposit of the twenty-second instrument of ratification or accession, the Convention shall enter into force on the thirtieth day after deposit by such State of its instrument of ratification or accession.

\section{Article 18}

1. Any State Party may denounce this Convention by written notification to the Secretary-General of the United Nations.

2. Denunciation shall take effect six months following the date on which notification is received by the Secretary-General of the United Nations.

\section{Article 19}

The Secretary-General of the United Nations shall inform all States, inter alia:

(a) of signatures to this Convention, of the deposit of instruments of ratification or accession in accordance with articles 14,15 and 16 and of notifications made under article 18;

(b) of the date on which this Convention will enter into force in accordance with article 17.

\section{Article 20}

The original of this Convention, of which the Chinese, English, French, Russian and Spanish texts are equally authentic, shall be deposited with the Secretary-General of the United Nations, who shall send certified copies thereof to all States.

IN WITNESS WHEREOF the undersigned, being duly authorized thereto by their respective Governments, have signed this Convention, opened for signature at New York on December 14, 1973. 


\section{SELECT BIBLIOGRAPHY}

1. Documents and Official Sources

a. Collections of Documents:

Brownlie, I. (Ed), Easic Documents in International Law (Clarendon Press, Oxford, 1933).

Friedlander, R.A. (Ed), Terrorism: Documents of International and Local Control, 3 Vols. (Oceania Publications, Dobbs Ferry, 1979).

b. Official (Australia):

Crimes (Internationalzy Protected Persons) Act 1976.

Diplomatic Privizeges and Immunities Act 1967.

Department of Administrative Services Annual Report 1981-82 (AGPS, Canberra, 1982).

Department of Foreign Affairs Annual Report 1983-84 (AGPS, Canberra, 1984).

Department of the Special Minister of State Annual Report 1982-83 (AGPS, Canberra, 1983).

Protective Security Review: Report (Unclassified Version) (AGPS, Canberra, 1979).

Report of the Proceedings of a study on the Protection of the Australian Public from Ionising Radiation (Australian Counter Disaster College, Mt. Macedon, 1983).

c. Official (Burma):

The Bomb Attack at the Martyr's Mausoleum in Rangoon: Report on the findings by the Enquiry Committee and the measures taken by the Burmese Government (Rangoon, 1934).

d. Official (United States of America):

Corsun, A., Armenian Terrorism: 1975-1980, Office of Security Threat Analysis Group, Research Papers on Terrorism (State Department, Washington, n.d.). 
Dam, K.W., 'Terrorism in the Middle East', Address by Kenneth W. Dam, Acting Secretary of State, to leaders of the National United Jewish Appeal, the White House, Washington, 1 October 1984, in Current Policy 618 (1 October 1984).

Perez, F.H., 'The Impact of International Terrorism', from an address by the Acting Director, Office for Combatting Terrorism on 29 October 1981, in By Ziner 1/82, No.5.

'Terrorist Target: The Diplomat', Address by Frank Perez, Deputy Director of the Office for Combatting Terrorism, before the Conference on Terrorism sponsored by the Instituto de Cuestiones Internacionales, Madrid, 10 June 1982, in Current Policy 402 (10 June 1982).

Sayre, R.M., 'International Terrorism: A Long Twilight Struggle', Address by Ambassador Robert M. Sayre, Director of the Office for Counterterrorism and Emergency Planning, before the Foreign Policy Association, New York, 15 August 1984, in Current Policy 608 (15 August 1984).

Shultz, G.P., 'Terrorism: The Problem and the Challenges', Statement by the Secretary of state before the House Committee on Foreign Affairs, Washington, 13 June 1984, in Current Policy 586 (13 June 1984).

'Terrorism: The Challenge to the Democracies', Address by the Secretary of state before the Jonathan Institute's Second Conference on International Terrorism, Washington, 24 June 1984, in Current Policy 589 (24 June 1984).

'Terrorism and the Modern World', Address by the Secretary of State before the Park Avenue Synagogue, New York, 25 October 1984.

Department of State Press Release No.242.

'International Terrorism', Gist (September 1984).

Patterns of International Terrorism: 1981 (State Department, Washington, 1982).

Terrorist Bombings: A Statistical Overview of International Terrorist Bombing Incidents from January 1977 through May 1983 (State Department, Washington, 1983).

Terrorist Incidents Involving Diplomats: A statistical overview of International Terrorist Incidents Involving Diplomatic Personnel and Facilities from January 1968 through Apriz 1983 (State Department, Washington, 1983). 


\section{Articles and Monographs}

a. Articles:

Clutterbuck, R., 'Diplomats Under Siege', The Army Quarterly and Defence Journal 111:2 (April 1981).

Fairbairn, G., 'International Terrorism', Pacific Defence Reporter 5:3 (September 1978).

Fawcett, J.E.S., 'Kidnappings versus Government Protection', World Today 26:9 (September 1970).

Fromkin, D., 'The Strategy of Terrorism', Foreign Affairs 53:4 (July 1975).

Gramont, S.de, 'How One Pleasant, Scholarly Young Man From Brazil Became a Kidnapping, Gun-Toting, Bombing Revolutionary', New York Times Magazine, 15 November 1970.

Hamer, J., 'Protection of Diplomats', Editorial Research Reports 11:13 (3 October 1973).

James, A., 'Diplomacy and International Society', International Relations 6:6 (November 1980).

Jenkins, B.M., 'International Terrorism: Trends and Potentialities', Journal of International Affairs $32: 1$ (1978).

'When the Yellow Ribbons Fade', Newsweek, 9 February 1981.

Keens-Soper, M., 'The Liberal Disposition of Diplomacy', International Relations 5:2 (November 1975).

Kirkpatrick, J.J., 'Defining Terrorism', Catholicism in Crisis (September 1984).

Mack, A., 'The Utility of Terrorism', Australia and New Zealand Journal of Criminology (December 1981).

Marshall, C.B., 'The Golden Age in Perspective', Journal of International Affairs 17:1 (1963).

Murphy, J.F., 'Report on Conference on International Terrorism: Protection of Diplomatic Premises and Personnel, Bellagio, Italy, March 8-12, 1982', Terrorism: An International Journal 6:3 (1983).

Nicolson, H., 'Diplomacy Then and Now', Foreign Affairs 1 (October 1961).

'Off the champagne trail: Diplomatic security abroad', Australian Foreign Affairs Record 54:5 (May 1983). 
Pierre, A.J., 'Coping With International Terrorism', Survival 18:2 (March/April 1976).

Poulantzas, N.M., 'Some Problems of International Law Connected with Urban Guerrilla Warfare: The Kidnapping of Members of Diplomatic Missions, Consular Officens and other Foreign Personnel', Annals of International Studies 3 (1972).

Shamwell, H.F., 'Implementing the Convention on the Prevention and Punishment of Crimes against Internationally Protected Persons, Including Diplomatic Agents', Terrorism: An International Journal 6:4 (1983).

Stechel, I., 'Terrorist Kidnapping of Diplomatic Personnel', Cornell International Law Journal 5:189 (Spring 1972).

Stohl, M., 'National Interests and State Terrorism in International Affairs', Political Science 36:1 (July 1984).

Thompson, W.S., 'Political Violence and the "Correlation of Forces"', Orbis 19:4 (Winter 1976).

Wardlaw, G., 'Terrorism: State involvement adds new dimension', Pacific Defence Reporter, Annual Reference Edition (December 1984/January 1985). 'When Diplomats Are Targets', US News and horld Report, 75:3
(16 July 1973).

Wilkinson, P., 'After Tehran', Conflict Quarterly (Spring 1981).

'Can a State be "Terrorist"?', International Affairs 57:3 (Summer 1981).

'State-sponsored international terrorism: the problems of response', The World Today (July 1984).

Wright, Q., 'The Decline of Classic Diplomacy', Journal of International Affairs 17 (1963).

Yoder, A., 'The Effectiveness of UN Action against International Terrorism: Conclusions and Comments', Terrorism: An International Journal $6: 4 \quad(1983)$.

'United Nations Resolutions against International Terrorism', Terrorism: An International Journal $6: 4$ (1983). 
b. Monographs:

Aston, C.C., Political Hostage Taking in western Europe, Conflict Studies 157 (Institute for the Study of Conflict, London, 1984).

Brenchley, F., Diplomatic Immunities and State-Sponsored Terrorism, Conflict Studies 164 (Institute for the Study of Conflict, London, 1984).

Civil Violence and the International System, Adelphi Papers 82 (Part 1) and 83 (Part 2) (International Institute for Strategic Studies, London, 1971).

Clissold, S., Croat Separatism: Nationalism, Dissidence and Terrorism, Conflict Studies 103 (Institute for the Study of Conflict, London, 1979).

Gutteridge, W. (Ed), Libya: Still a Threat to Western Interests? Conflict Studies 160 (Institute for the Study of Conflict, London, 1984).

Moxon-Browne, E., Terrorism in France, Conflict Studies 144 (Institute for the Study of Conflict, London, 1983).

Jenkins, B.M., Combatting Terrorism Becomes a War, Rand Paper P-6988 (Rand Corporation, Santa Monica, 1984).

Diplomats on the Front Line, Rand Paper P-6749 (Rand Corporation, Santa Monica, 1982).

Embassies Under Siege: A Review of 48 Embassy Takeovers, 1971-1980, Rand Report R-2651-RC (Rand Corporation, Santa Monica, 1981).

High Technology Terrorism and Surrogate War: The Impact of New Technology on Low-Level Violence, Rand Paper P-5339 (Rand Corporation, Santa Monica, 1975).

The Lessons of Beirut: Testimony Before the Long Commission, Rand Note N-2ll4-RC (Rand Corporation, Santa Monica, 1984).

New Modes of Conflict, Rand Report R-3009-DNA (Rand Corporation, Santa Monica, 1983).

Talking to Terrorists, Rand Paper P-6750 (Rand Corporation, Santa Monica, 1982).

Jenkins, B.M. and Johnson, J., International Terrorism: A Chronology 1968-1974, Rand Report R-1597-DOS/ARPA (Rand Corporation, Santa Monica, 1975). 
Jenkins, B.M., Johnson, J. and Ronfeldt, D., Numbered Lives: Some Statistical observations from 77 International Hostage Episodes, Rand Paper P-5905 (Rand Corporation, Santa Monica, 1977).

Rees, D., North Korea's Growth as a Subversive Centre, Conflict Studies 28 (Institute for the Study of Conflict, London, 1972).

Wilkinson, P., Terrorism: International Dimensions Answering the Challenge, Conflict Studies 113 (Institute for the Study of Conflict, London, 1979).

Terrorism versus Liberal Democracy - The Problems of Response, Conflict Studies 67 (Institute for the Study of Conflict, London, 1976).

3. Other Published Works

Alexander, Y. (Ed), International Terrorism: National, Regional and Global Perspectives (Praeger, New York, 1976).

Alexander, Y., Carlton, D. and Wilkinson, P. (Eds), Terrorism: Theory and Practice (Westview Press, Boulder, 1979).

Aron, R., Peace and har: A Theory of International Relations (Praeger, New York, 1970).

Barber, P., Diplomacy (The British Library, London, 1979).

Bassiouni, M.C. (Ed), International Terrorism and Political Crimes (Charles Thomas, Springfield, 1975).

Baumann, C.E., The Diplomatic Kidnappings, A Revolutionary Tactic of Urban Terrorism (Martinus Nijhoff, The Hague, 1973).

Begin, M., The Revolt (W.H. Allen, London, 1951).

Bell, J.B., A Time of Terror: How Democratic Societies Respond to Revolutionary Violence (Basic Books, New York, 1978).

Boyce, P.J., Foreign Affairs For New States: Some Questions of Credentials (University of Queensland Press, St. Lucia, 1977).

Bull, H., The Anarchical Society: A Study of order in world Politics (Macmillan, London, 1983).

Bull, H. and Watson, A. (Eds), The Expansion of International Society (Clarendon Press, Oxford, 1984). 
Carlton, D. and Schaerf, C. (Eds), International Terrorism and World Security (Croom Helm, London, 1975).

Cline, R.S. and Alexander, Y., Terrorism: The Soviet Connection (Crane Russak, New York, 1984).

Clutterbuck, R., Living iith Terrorism (Faber, London, 1975).

Debray, R., Revolution in the Revolution? Armed Struggle and Political struggle in Latin America (Penguin, Harmondsworth, 1968).

Dobson, $\mathrm{C}$. and Payne, R., The Weapons of Terror: International Terrorism at Work (Macmillan, London, 1979).

Terror! The hest Fights Back (Macmillan, London, 1982).

Eayrs, J., Diplomacy and Its Discontents (University of Toronto Press, Toronto, 1971).

Eckstein, H. (Ed), Internal har: Problems and Approaches (Collier-Macmillan, London, 1964).

Evans, A.E. and Murphy, J.F. (Eds), Legal Aspects of International Terrorism (Heath and Co., Lexington, 1978).

Grivas, G., The Memoirs of George Grivas (Longmans, London, $1964)$.

Guevara, E., Guerrizza Warfare (Penguin, Harmondsworth, 1969).

Herz, M.F. (Ed), Diplomats and Terrorists: What Works, what Doesn't: A Symposium (Institute for the Study of Diplomacy (Georgetown University), Washington, 1982).

Janke, P., Guerrizla and Terrorist Organisations: A world Directory and Bibliography (Harvester Press, Brighton, 1983).

Katz, R., Days of hirath: The Public Agony of Aldo Moro (Granada, London, 1980).

Keohane, R.O. and Nye, J.S. (Eds), Transnational Relations and World Politics (Harvard University Press, Cambridge, 1981).

Laqueur, W., Terrorism (Abacus, London, 1978).

(Ed), The Terrorism Reader: A Historical Anthology (Wildwood House, London, 1979).

Lodge, J. (Ed), Terrorism: A Challenge to the State (Martin Robertson, Oxford, 1981). 
Livingston, M.H. (Ed), International Terrorism in the Contemporary World (Greenwood Press, Westport, 1978).

Marighela, C., For The Liberation of Brazil (Penguin, Harmondsworth, 1971).

Miller, J.D.B., The world of States (Croom Helm, London, 1981).

Moss, R., Urban Guerrizzas: The New Face of Political Violence (Alister Taylor, Wellington, 1972).

Nicolson, H., Diplomacy (Oxford University Press, London, 1969). The Evolution of the Diplomatic Method: Being the Chichele Lectures delivered at the University of oxford in November' 1953 (Constable, London, 1954).

Satow, E., A Guide to Diplomatic Practice (Longmans, Green and Co., London, 1957).

Schelling, T.C., Arms and Influence (Yale University Press, New Haven, 1966).

Schlesinger, P., Murdock, G. and Elliott, P., Televising Terrorism: Political Violence in Popular culture (Comedia Publishing Group, London, 1983).

Semmel, B., Marxism and the Science of War (Oxford University Press, Oxford, 1981).

Sen, B., A Diplomat's Handbook of International Law and Practice (Martinus Nijhoff, The Hague, 1979).

Shultz, R.H. and Sloan, S. (Eds), Responding to the Terrorist Threat: Security and Crisis Management (Pergamon Press, New York, 1980).

Sterling, C., The Terror Network: The Secret war of International Terrorism (Holt, Rinehart and Winston, New York, 1981).

Stohl, M. (Ed), The Politics of Terrorism (Dekker, New York, 1979).

'Sunday Times' Insight Team, Siege! Princes Gate, London, April 30-May 51980 (Hamlyn, London, 1980).

Wardlaw, G., Political Terrorism: Theory, Tactics and CounterMeasures (Cambridge University Press, Cambridge, 1982).

Watson, A., Diplomacy: The DiaZogue Between States (Eyre Methuen, London, 1982). 
Wight, M., Power Politics (Leicester University Press, Leicester, 1978).

Wilkinson, P., Political Terrorism (Macmillan, London, 1974). Terrorism and the Liberal State (Macmillan, London, 1977.).

Wilson, C.E., Diplomatic Privileges and Immunities (University of Arizona Press, Tucson, 1967).

\section{Unpublished Works}

Crenshaw, M., 'The International Consequences of Terrorism', Paper prepared for delivery at the 1983 Annual Meeting of the American Political Science Association, The Palmer House, 1-4 September 1983 .

'International Terrorism', Address by the Head, Protective Services Coordination Centre, to the Joint Services Staff College, Canberra, 22 February 1983.

Wardlaw, G., 'Strategic Aspects of Political Terrorism', Address to the Joint Services Staff College, Canberra, 29 February 1984.

'Terrorism, Counter-Terrorism and the Democratic Society', draft chapter prepared for inclusion in Stohl, M. and Lopez, G.A. (Eds), State Terrorism: New Perspectives for Research (Forthcoming). 